\title{
UMA AVALIAÇÃO DO PROGRAMA DE FORMAÇÃO DE JOVENS EMPRESÁRIOS RURAIS - PROJOVEM
}

\author{
DANIELA CRISTINA MANHANI \\ Bacharel em Ciências Econômicas
}

Orientador: Prof. Dr. FERNANDO CURI PERES

Dissertação apresentada à Escola Superior de Agricultura "Luiz de Queiroz", Universidade de São Paulo, para obtenção do título de Mestre em Ciências, Área de Concentração: Economia Aplicada.

PIRACICABA

Estado de São Paulo - Brasil

Abril - 2000 
Dados Internacionais de Catalogação na Publicação (CIP)

DIVISÃO DE BIBLIOTECA E DOCUMENTAÇĀO - Campus "Luiz de Queiroz"/USP

Manhani, Daniela Cristina

Uma avaliação do programa de formação de jovens empresários rurais PROJOVEM / Daniela Cristina Manhani. - - Piracicaba, 2000.

$118 \mathrm{p}$.

Dissertação (mestrado) - - Escola Superior de Agricultura Luiz de Queiroz, 2000.

Bibliografia.

1. Análise sácio-econômica 2. Educação agrícola 3. Empresário agrícola 4. Pedagogia de altemância I. Título

CDD 630.7 
À minha mãe,

OFEREÇO

\section{DEDICO}

Ao meu pai e irmãos que nunca mediram esforços para o meu desenvolvimento e sempre estiveram ao meu lado. 


\section{Agradecimentos}

Ao Prof. Almério Melquíades de Araujo, Coordenador do Ensino Técnico do Centro Estadual de Educação Tecnológica Paula Souza (CEETEPS), pela sugestão e estímulo à realização desta pesquisa. Tem sido uma grande honra participar da ampliação do escopo do CEETEPS no atendimento à camada de jovens que o Sr. Superintendente do CEETEPS chama de "credores do Estado".

Ao Prof. Fernando Curi Peres, pela amizade demonstrada, pela orientação segura, pelo incentivo constante e pela lição de vida que este estudo me proporcionou.

À Prof. Maria Christina Siqueira de Souza Campos, da Faculdade de Economia, Administração e Contabilidade de Ribeirão Preto (FEA/USP-RP), pelo exemplo de competência, pelos seus ensinamentos e pela amizade. Ao Prof. Dr. Joaquim Bento de Souza Ferreira Filho, pelas críticas e sugestões indispensáveis para a realização deste trabalho.

À Coordenação de Aperfeiçoamento de Pessoal de Nível Superior (CAPES- MEC) e à Fundação W.K.Kellogg, através do Projeto UNIR, pelo apoio financeiro.

Ao Corpo Docente do Departamento de Economia, Administração e Sociologia da ESALQUSP, pelos conhecimentos transmitidos e, em especial a Evaristo Marzabal Neves e João Gomes Martinez pelas sugestões para o aperfeiçoamento deste trabalho.

À todos os meus companheiros de turma, com os quais tive o privilégio de conviver e muito aprender. Aos demais colegas de pós graduação, pelo apoio, amizade e agradável convivência durante o curso.

Aos funcionários do Departamento que estiveram sempre prontos a ajudar: Maielli, Valdeci, Ligiana, Cristiane, Pedro, Helena, Márcia, Elenice e Maria Helena. À Luciane eu agradeço, além de tudo, pela atenção e amizade. 
À Tia Letícia, que sempre esteve ao meu lado, dando apoio para superar todas as dificuldades do meu caminho.

Aos meus sobrinhos, fonte de alegria constante em minha vida.

Ao Fabio, pelo companheirismo, apoio, carinho e paciência com que me suportou durante a fase de realização deste trabalho.

À todos que de uma forma ou de outra participaram da concretização deste trabalho. 


\section{SUMÁRIO}

Página

LISTA DE FIGURAS.................................................................................. vii

LISTA DE QUADROS ................................................................................ ix

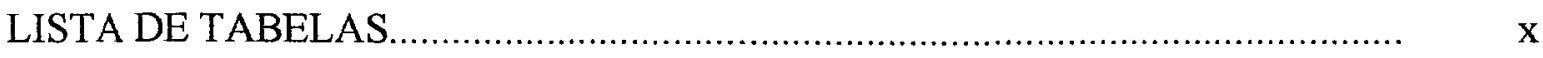

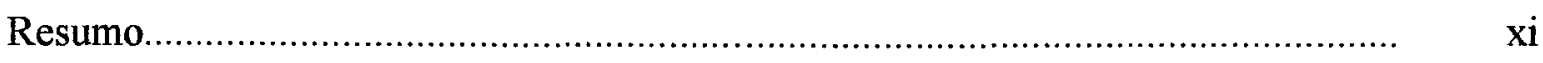

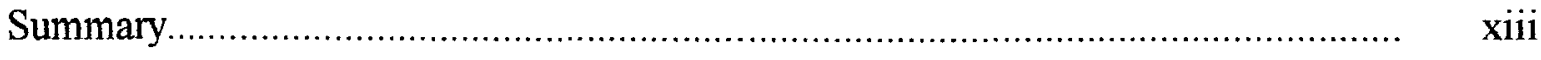

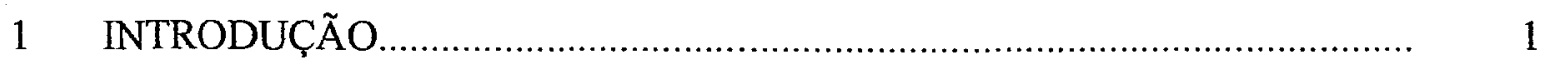

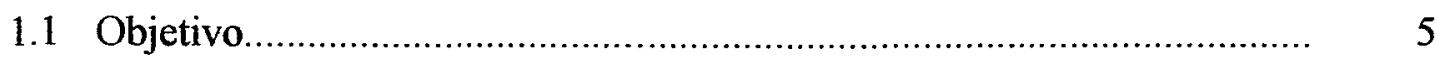

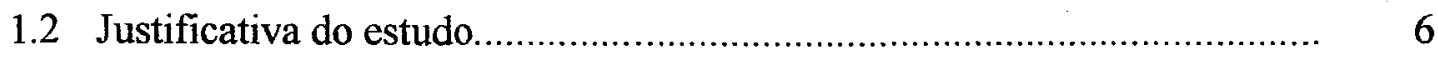

1.3 Estrutura do trabalho ............................................................................ 7

2 O PROGRAMA DE FORMAÇÃO DE JOVENS EMPRESÁRIOS RURAIS.... 8

2.1 Justificativa para a criação do PROJOVEM............................................... 8

2.2 O Programa de Formação de Jovens Empresários Rurais.......................... 13

3 TEORIA DO CAPITAL HUMANO................................................................ 22

$4 \quad$ REVISÃO DE LITERATURA............................................................. 32

5 METODOLOGIA E PLANO DE COLETA DE DADOS.................................. 49

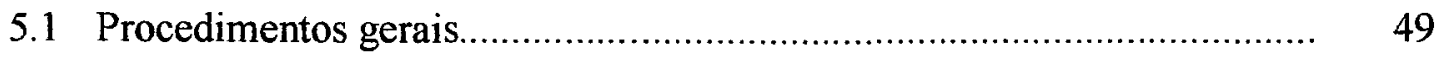

5.2 Definição da amostra.......................................................................... 49

5.3 Os núcleos sorteados...................................................................... 51

5.4 Critério definidores para a coleta de dados primários................................ 54

5.4.1 Forma de obtenção dos dados....................................................... 54

5.4 .2 Pessoas entrevistadas................................................................ 55

5.5 Tratamento das informações................................................................ 56

5.6 O cálculo da Taxa Interna de Retorno....................................................... 57 
5.6.1 Descrição das variáveis envolvidas no cálculo da Taxa Interna de

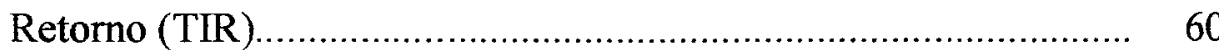

6 ANÁLISE E DISCUSSÃO DOS RESULTADOS .............................................. 65

6.1 Características gerais dos indivíduos que compõem o Programa de 65 Formação de Jovens Empresário Rurais

6.2 A resposta às questões de investigação levantadas...................................... 78

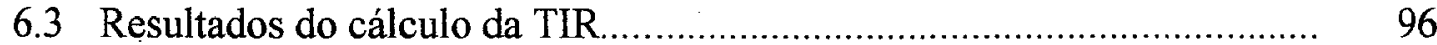

7 CONCLUSÃO

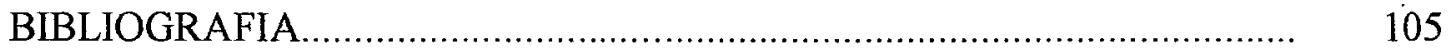

APÊNDICES 


\section{LISTA DE FIGURAS}

Página

1 Evolução da renda ao longo da vida de um indivíduo................................ 25

2 Despesas totais envolvidas na educação oferecida pelo PROJOVEM............. 59 


\section{LISTA DE QUADROS}

Página

1 Principais informações sobre os núcleos que compõem o PROJOVEM........ 15 


\section{LISTA DE TABELAS}

Página

5.1 Distribuição numérica e percentual dos jovens freqüentadores e entrevistados 55 dos núcleos sorteados - 1999

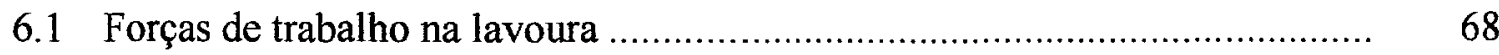

6.2 Técnicas aprendidas ou aperfeiçoadas pelos jovens no PROJOVEM.............. 73

6.3 Gasto total por jovem nos 4 núcleos pesquisados do PROJOVEM durante o 97 ano de 1998 .

6.4 Gasto total por aluno das 35 escolas agrícolas mantidas pelo CEETEPS no 100 ano de 1997 


\title{
UMA AVALIAÇÃO DO PROGRAMA DE FORMAÇÃO DE JOVENS EMPRESÁRIOS RURAIS - PROJOVEM
}

\author{
Autora: Daniela Cristina Manhani \\ Orientador: Fernando Curi Peres
}

\section{RESUMO}

Este estudo analisa vantagens econômicas e sociais advindas da implantação do Programa de Formação de Jovens Empresários Rurais (PROJOVEM). Trata-se de um programa que utiliza metodologia diferenciada baseada na pedagogia de alternância, no construtivismo e na elaboração e implantação de projeto de investimento individual. Este programa visa atender os jovens, filhos de pequenos produtores, de parceiros e de trabalhadores rurais, deficientes em recursos físicos, financeiros e humanos a fim de torná-los empresários rurais.

São utilizados dados primários e secundários. A fonte primária de informações utilizada neste estudo foi obtida por meio de entrevistas. A entrevista forneceu os dados necessários à análise sócio-econômica, das expectativas dos jovens e suas famílias e ao cálculo da taxa interna de retorno. Os dados secundários foram conseguidos junto ao CEETEPS, estatísticas do IBGE e outras fontes da literatura.

O estudo mostrou que o PROJOVEM atende principalmente familias carentes do meio rural e jovens interessados em trabalhar e permanecer no campo, sendo que algumas mudanças de caráter social, comportamental e econômicas já são visíveis. Os jovens estão mais integrados à comunidade, mais interessados pelo trabalho, melhoraram o relacionamento com a familia, introduzem novas técnicas na propriedade e, com a aplicação do que eles aprenderam durante a implantação do projeto de investimento, têm chances de aumentar a renda da família de maneira sustentada e continuada. 
A análise sobre a função dos monitores dentro do programa detectou falhas na formação de alguns, apesar de possuírem conhecimento técnico alguns não possuem vivência empresarial e nem prática com a metodologia de ensino proposta pelo PROJOVEM. Entretanto, eles conseguem, por meio de aulas diferenciadas que retratam o ambiente do jovem, despertar seu interesse e participação no programa.

O cálculo da taxa interna de retorno mostrou que é mais vantajoso para o jovem rural cursar o PROJOVEM e implantar seu projeto de investimento que permanecer no campo como trabalhador rural ou ir para a cidade se dedicar a emprego não qualificado. A partir do momento que o programa possibilita rendimentos maiores no campo que na cidade, o setor urbano deixa de ser tão atrativo para o jovem rural.

Os resultados permitem concluir que o PROJOVEM é um programa desejável tanto do ponto de vista econômico como social, podendo contribuir para o fortalecimento da agricultura familiar e tornar-se um fator de desenvolvimento das regiões mais carentes. 


\title{
AN EVALUATION OF THE "PROGRAM TO DEVELOP ENTREPRENEURSHIP ABILITIES IN RURAL YOUTH" - PROJOVEM
}

\author{
Author: Daniela Cristina Manhani \\ Adviser: Fernando Curi Peres
}

\section{SUMMARY}

The Program to Develop Entrepreneurship Abilities in Rural Youth (PROJOVEM) is evaluated. The program works with a different methodology based on the (a) "alternate pedagogy", on (b) J. Piaget's suggestion to stimulate the construction of knowledge, and on (c) the writing and implementing of a capital investment project by the student. It is a learning by doing strategy that aims to turn them into rural entrepreneurs.

The research used data from direct interviews and from secondary sources. The first were the data sources for the social-economic analysis, the evaluation of the internal rate of return, and for measuring the students and their families' income and educational expectations. Secondary data were obtained from The Technological Educational State Centre (CEETEPS), The Brazilian Institute of Geography and Statistics (IBGE), and from other sources.

The study showed that PROJOVEM is specially important for rural families and youths interested in working and living in rural regions. Some social, behavioural, and economic changes have already been noticed, such as better relations of the youths with their families and their stronger commitments to work with their communities. Based on what they have learned with the investment project, students are introducing new production and management techniques into their family farms. This is an important step toward the goal of increasing the family income in a sustained and continuos way.

The evaluation of the monitors' (teachers) work showed that they don't have enough management experience to be able to fully motivate students to face the risks and to 
pursue the goals associated with entrepreneurs' activities. On the other hand, they manage to stimulate student's participation in the program through class undertakings based on problems faced by the students in their working environment.

The evaluation of the internal rate of return showed the advantage for the students to participate in PROJOVEM and work as entrepreneurs rather than staying in rural activities as farm workers or moving to urban areas and become non-qualified workers. When the program gives rural youths the chance of obtaining a greater income than they would in the city moving to urban areas become less attractive to them.

Results from this study lead to the conclusion that PROJOVEM is socially and economically desirable. It can contribute to strengthening familiar agriculture and developing rural regions. 
"... o desejo de melhorar nossa condição... vem conosco do útero e nunca nos deixa até baixarmos ao túmulo".

Adam Smith

\section{INTRODUÇÃO}

Atualmente existe na sociedade um consenso sobre a importância exercida pela educação no desenvolvimento dos países. O aperfeiçoamento científico e as intensas mudanças tecnológicas ocorridas no mundo atual, em particular no Brasil, mostram que nenhuma providência é tão necessária quanto a educação. O Japão no pós-guerra e os Tigres Asiáticos ${ }^{1}$ nos dias de hoje creditam grande parte de seu crescimento econômico às atividades relacionadas à formação educacional de seus habitantes. A preocupação de vários países desenvolvidos, como os Estados Unidos, com a concorrência dos produtos japoneses e de outros países tem feito com que eles repensem todo seu sistema educacional. Diante destes fatos, pode-se verificar que a educação é uma política estratégica de fundamental importância tanto nos paises desenvolvidos como naqueles em busca do desenvolvimento, ou seja, a educação é fundamental tanto para sair da miséria quanto para manter o nível de bem-estar.

Os setores industrial e de serviços foram os primeiros a perceber que não se compete de forma contínua no mercado globalizado com operários de baixa formação educacional. A educação é um dos muitos modos de desenvolver os recursos humanos em uma sociedade, sendo capaz de contribuir para o crescimento econômico do país, como foi mostrado por diversos estudos realizados a partir da década de 60 . Entretanto, na maioria dos países em desenvolvimento, como o Brasil, o sistema educacional é falho e dispendioso. Os investimentos em educação no Brasil atingem aproximadamente $4 \%$ do PIB, quantia que pode ser considerada alta, dada a qualidade do ensino oferecido pelo

\footnotetext{
${ }^{1}$ Países em desenvolvimento do leste asiático que alcançaram elevadas taxas de crescimento econômico nos últimos anos. Por exemplo, Coréia do Sul e Formosa.
} 
sistema público, principalmente quando comparadas aos investimentos da Coréia, 4,5\% do PIB e dos Estados Unidos, 7, 5\% do PIB (Exame, set./1997, p. 13).

$\mathrm{Na}$ agricultura, vive-se neste momento os impactos da globalização, onde a competição deixou de ocorrer apenas entre vizinhos e passou a ser mundial. Dentro deste contexto, discutem-se políticas econômicas, cambiais, agrícolas, sanitárias, tecnológicas e outras mais. Apesar de se tratar de esforços valiosos, parece claro que é exigir demais que agricultores analfabetos, ou que no máximo cursaram há muito tempo o quarto ano primário, possam competir com agricultores americanos ou europeus, com capacidade de absorver tecnologias e compreender a realidade em que vivem. Diante das exigências provocadas pela conseqüente reestruturação produtiva, o perfil do trabalhador agrícola (proprietário ou não) necessita mudar para acompanhar o ritmo imposto pela modernização. No mundo atual, não basta destreza manual e força física para sobreviver. É preciso também iniciativa, criatividade, intuição, motivação e capacidade para assumir riscos (Zimmermann, 1995). Devido a isso, a educação passa a ocupar papel fundamental na formação dos jovens.

A educação, segundo Becker (1993), além de impulsionar o desenvolvimento econômico, aumenta a igualdade de oportunidades, principalmente entre as camadas mais pobres da população. Entretanto, o sistema educacional brasileiro privilegia alguns grupos da sociedade. De acordo com Harbison \& Myers (1965), a plena escolaridade primária, objetivo comum de todos os países parcialmente desenvolvidos, só se encontra disponivel para as crianças e jovens nos centros urbanos e cidades maiores, atingindo pouco a população rural.

Nos últimos anos ocorreu uma evolução nos resultados referentes à educação. A Pesquisa Nacional por Amostra de Domicílio (PNAD, 1998) mostra que o número de crianças entre 7 e 14 anos que estão fora da sala de aula caiu de 11,5\% em 1993, para $5,3 \% \mathrm{em} \mathrm{1998.} \mathrm{O} \mathrm{número} \mathrm{de} \mathrm{crianças} \mathrm{que} \mathrm{concluiu} \mathrm{o} \mathrm{primeiro} \mathrm{grau} \mathrm{em} 1998$ dobrou em 
comparação com o ano de 1992. Esses resultados mostram uma melhora no nível educacional brasileiro, mas que ainda é insuficiente para atender aos níveis exigidos pelas modernas técnicas de produção. Como se pode observar, está ocorrendo uma universalização do ensino, atingindo o meio rural e urbano. Apesar desta evolução, as dificuldades para os jovens rurais permanecem. Grande parte deles tem de se deslocar de suas casas para as cidades em busca de escolas que oferecem um tipo de ensino desvinculado da sua realidade. Os jovens rurais que querem permanecer no campo têm poucas chances de conseguir uma renda que permita elevar seu padrão de vida. Sem muitas perspectivas, os filhos de pequenos proprietários, parceiros ou trabalhadores saem freqüentemente do campo para engrossar a massa de trabalhadores de baixa qualificação nos centros urbanos, onde vão viver em condições precárias, já que as cidades não possuem empregos suficientes para absorver os migrantes.

Como uma das alternativas para o setor agrícola, criou-se o Programa de Formação de Jovens Empresários Rurais - PROJOVEM, iniciado em fins de 1995 de uma parceria entre o Centro Estadual de Educação Tecnológica Paula Souza (CEETEPS) e o Projeto UNIR (Uma Nova Iniciativa de Desenvolvimento Rural) da USP, na Escola Superior de Agricultura Luiz de Queiroz. Trata-se de um programa educacional diferenciado, voltado para uma clientela de origem rural (filhos de pequenos proprietários, parceiros ou empregados), cuja finalidade é preparar os jovens para serem empreendedores ou empresários rurais com capacidade para desenvolverem suas próprias atividades de maneira sustentada e competitiva, de forma que possam cooperar para o aumento da qualidade de vida ${ }^{2}$ de suas famílias (Peres et al.,1998). O PROJOVEM oferece conhecimento aliado à prática, abrindo novas perspectivas de rentabilidade e sustentabilidade, permitindo que os pequenos estabelecimentos resistam ao processo de "seleção natural" onde somente os mais aptos sobrevivem.

\footnotetext{
${ }^{2}$ Qualidade de vida refere-se às condiçōes necessárias às pessoas, famílias ou comunidades para satisfazer suas necessidades básicas, sociais e culturais, indispensáveis ao desenvolvimento normal do homem e à utilização responsável da sua capacidade, considerando seu meio ambiente fisico e natural.
} 
O PROJOVEM é um programa que depende financeiramente de outras instituições para sobreviver. Atualmente, o maior parceiro do PROJOVEM é o CEETEPS, responsável pelo pagamento dos salários dos monitores e cozinheiros, entre outras coisas. O CEETEPS é uma autarquia do governo do Estado de São Paulo destinada a promover educação profissional pública de nível básico, técnico e tecnológico. Por essa razão, é um dos principais interessados, assim como a sociedade, em saber se realmente vale a pena continuar investindo num programa com as características do PROJOVEM.

Em um trabalho realizado anteriormente (Burke, 1998), a proposta pedagógica do PROJOVEM foi analisada e concluiu-se que o programa está cumprindo satisfatoriamente o propósito pedagógico para o qual foi designado. O tripé pedagógico escolhido para sustentar seu desenvolvimento (projeto individual de investimento, pedagogia da alternância e "construtivismo") foi considerado suficiente e eficaz na missão de preparar os jovens para se tornarem empresários rurais. Nas palavras de Burke, "se existe um processo capaz de preparar os jovens filhos de agricultores para serem empresários rurais, então o escolhido foi, sem dúvida o melhor possível". Entretanto, Burke chama a atenção, "o trajeto é difícil e pouco trilhado, há pedras no caminho...Se por alguma razão, alguns não puderem chegar ao destino, mesmo assim a caminhada lhes terá ensinado muitas coisas, que lhes serão extremamente úteis pelo resto de suas vidas" (Burke, 1998, p. 12).

Comprovada a eficácia da pedagogia utilizada pelo programa, faz-se necessário buscar outros argumentos que justifiquem o seu prosseguimento e provem sua necessidade, visto que ele necessita ser financiado para continuar. O PROJOVEM está cumprindo seus objetivos de forma eficiente? Os custos incorridos são justificáveis? Os retornos sustentam a continuidade do programa? Estas são perguntas que precisam ser

\footnotetext{
${ }^{3}$ Este termo é utilizado normalmente para se referir à teoria sobre o processo pelo qual as pessoas aprendem e constroem seus próprios conhecimentos (Burke, 1998).
} 
respondidas para que as instituições, especialmente as públicas, continuem, ou não, a alocar recursos para o programa.

Os instrumentos utilizados para buscar essas respostas são, basicamente, entrevistas e o cálculo da taxa interna de retorno, recursos que permitirão analisar o desempenho do programa e que serão melhor explicados no capítulo 5. No momento em que este estudo foi realizado, o PROJOVEM não possuía nenhuma turma de jovens formados, o que levou à utilização de proxies que pudessem preencher, o mais próximo possível da realidade, os dados necessários para a execução deste estudo.

\subsection{Objetivo}

O estudo pretende avaliar as vantagens econômicas e sociais da implantação de um programa de educação diferenciada, ou seja, se os "retornos" do programa compensam os "investimentos" realizados pelas famílias e pelos parceiros do PROJOVEM".

Para realizar este trabalho e cumprir o objetivo descrito, algumas etapas foram seguidas:

1- Analisar as características socioeconômicas dos jovens e suas famílias, assim como, as expectativas e os primeiros efeitos causados pelo PROJOVEM nas famílias envolvidas. É preciso reconhecer o público atendido pelo programa e captar algumas mudanças (comportamentais, econômicas, sociais, etc.) introduzidas a partir da participação dos jovens no mesmo;

2- Analisar as características e o comportamento pedagógico dos monitores para saber se eles são capazes de contribuir para a formação de jovens empresários rurais;

\footnotetext{
${ }^{4}$ As palavras retorno e investimentos estão sendo utilizadas não apenas do ponto de vista econômico, mas também social.
} 
3- Levantar e verificar questões que fortaleçam (ou neguem) a necessidade de um programa como o PROJOVEM a partir da discussão sobre as potencialidades da educação no meio rural;

4- Calcular a taxa interna de retorno advinda do investimento realizado no PROJOVEM para ter noção da capacidade de influenciar economicamente o padrão de vida das famílias envolvidas.

\subsection{Justificativa do estudo}

O PROJOVEM é um programa voltado a uma parcela da população sem muitas oportunidades e que dificilmente consegue se beneficiar das políticas públicas criadas para melhorar o padrão de vida no campo. No momento desta pesquisa, o programa atendia aproximadamente 183 jovens e familias espalhadas por 9 cidades do interior de São Paulo. Os números atingidos pelo programa ainda são muito pequenos em relação à população potencial que existe. Para se ter idéia, no Estado de São Paulo as pequenas propriedades (com menos de 20 ha) totalizam, de acordo com o Censo Agropecuário de 1996, 108.026 estabelecimentos. Vivem no meio rural paulista 3.306 .673 pessoas (aproximadamente 7,5\% da população total do Estado), sendo que 1.235.713 têm menos de 24 anos. Destes jovens, aproximadamente 73\% concluíram apenas o ensino básico. Além disso, dentre os núcleos do PROJOVEM, quatro atendem áreas de assentamento rural. Segundo levantamento feito pelo Instituto de Terras do Estado de São Paulo (Cadernos do ITESP 1, abril de 1998), em 1997 existiam no Estado 76 projetos de assentamento rural beneficiando mais de 5.000 famílias. São mais de 20.000 pessoas vivendo em assentamentos criados recentemente com pouca ou nenhuma experiência em gestão agrícola. Portanto, o PROJOVEM, pela clientela que atende, pela natureza dos serviços que presta e pelas possíveis potencialidades em termos de resultados, pode se tornar uma opção abrangente de amparo aos jovens rurais e pequenos agricultores que desejam permanecer no campo. 
A análise da viabilidade econômica e social de programas educacionais diferenciados para o meio rural, no estilo do PROJOVEM, é um recurso pouco utilizado para justificar sua existência. O recurso frequientemente usado para comprovar as vantagens de programas deste tipo se restringe a avaliações pedagógicas, o que não é suficiente para comprovar a eficiência do programa em todos os seus aspectos. $O$ estudo proposto por este trabalho é oportuno, tanto com o objetivo de confirmar ou não as grandes expectativas que têm desencadeado, como também para identificar pontos críticos e ajustes no funcionamento, possibilitando aprimorar o seu desempenho.

\subsection{Estrutura do trabalho}

Além dessa introdução, o presente trabalho é composto de mais seis capitulos. No capítulo 2 são relatados os motivos para a criação do PROJOVEM e suas possibilidades econômicas e sociais. No capítulo 3, a Teoria do Capital Humano e a maneira de se calcular o retorno aos investimentos educacionais são discutidos do ponto de vista de seus principais autores. Em seguida, no capítulo 4, inicia-se a fase de apresentação e discussão dos trabalhos já realizados sobre retornos advindos da educação, experiências educacionais voltadas aos jovens rurais e utilização de conhecimentos administrativos no meio rural. O capítulo 5 expõe a metodologia utilizada, definindo a forma de coleta dos dados e o tratamento das informações necessárias para o cumprimento dos objetivos. No capítulo 6 são apresentados os resultados e as discussões sobre a viabilidade de se investir num programa como o PROJOVEM. Finalmente, no capítulo 7 são expostas as conclusões do trabalho. 
"O importante é não seguir nunca os caminhos já trilhados, mas procurar sempre novos atalhos".

Alexander Graham Bell

\section{O PROGRAMA DE FORMAÇÃO DE JOVENS EMPRESÁRIOS RURAIS}

\subsection{Justificativa para a criação do PROJOVEM}

Atualmente, o grande problema enfrentado pelos jovens, filhos de pequenos produtores rurais (proprietários ou não), tem sido a falta de emprego no campo. Esta situação se deve essencialmente a dois fatores. O primeiro refere-se ao tipo de trabalho que está sendo exigido pela nova ordem econômica. A busca por novos processos organizacionais capazes de diminuir os custos da administração do trabalho e os riscos assumidos pela firma reduz as chances de emprego formal em todos os setores da economia. O segundo fator é atribuído à ineficiência do sistema educacional formal nas áreas rurais. $O$ conteúdo e a qualidade do ensino oferecido na zona rural não atendem às necessidades dos jovens. A carência de investimentos em recursos humanos no campo é agravada pelo corporativismo do sistema público, que dificulta a participação das famílias, principalmente as mais carentes, nas decisões quanto ao tipo de educação oferecido a seus filhos e pelo processo de migração rural-urbano, que atrai os jovens rurais em busca da possibilidade de auferir maiores rendas nas cidades, uma vez que a renda urbana é maior que a renda rural, pois o setor rural sempre foi mais exposto à competição (Peres et al., 1998).

O aumento da competição causado pela globalização tem feito as indústrias urbanas buscarem formas mais efícientes de administração, procurando aumentar a produtividade do trabalho e ao mesmo tempo reduzir custos e riscos. A abertura de mercado, expondo o setor urbano à competição de produtos internacionais, tem forçado as empresas nacionais a adotar como estratégia uma técnica de administração muito 
comum nas empresas rurais, conhecida como parceria. A parceria no meio rural serve para aumentar a eficiência administrativa e reduzir os riscos e custos de produção. Esse tipo de estratégia, no setor urbano, recebe o nome de terceirização (Peres et al., 1998). Diante da tendência contínua dos efeitos da globalização, existe a necessidade de preparação dos recursos humanos para torná-los capazes de criar seu próprio local de trabalho. Este preparo deve atender especialmente ao jovem do meio rural, pois o setor é extremamente carente de investimentos em capital humano e a escola rural, da forma como funciona, dificilmente será capaz de mudar essa realidade.

A escola, segundo os ensinamentos de Arnaldo Niskier (1992), tem dois objetivos básicos: primeiro, educar o cidadão para o convívio social e, segundo, educar o indivíduo no campo técnico e da ciência, com o sentimento de prepará-lo para o exercício da atividade econômica, com maior eficiência e criatividade. $O$ sistema educacional brasileiro não tem sido capaz de assegurar o cumprimento destes objetivos, que só são concedidos a uma parcela da população, comumente aquela que reside nos centros urbanos.

As escolas situadas no meio rural são extremamente deficientes no desempenho de seus objetivos. De acordo com Werthein \& Bordenave (1981), elas apresentam um diagnóstico que é comum à maioria dos países subdesenvolvidos: a) a educação oferecida nas zonas rurais não corresponde às necessidades de seus habitantes; b) o conteúdo e o método de ensino que caracterizam a educação urbana são transmitidos diretamente para as zonas rurais; c) o calendário escolar não atende às características da produção; d) os problemas de evasão e repetência são mais graves que os encontrados na zona urbana, sendo também elevado o índice de analfabetismo; e) os professores são mal preparados e a remuneração do magistério é baixa; f) a escola, estruturada de maneira muito semelhante à escola urbana, encontra-se quase totalmente desvinculada da comunidade a que pertence; e g) há deficiência de material escolar e equipamentos. 
Atualmente, as escolas públicas no meio rural são quase inexistentes. As crianças e jovens que desejam estudar precisam se locomover até as cidades dispostos a receber uma educação quase completamente desligada dos seus interesses e necessidades. Esse é, provavelmente, um dos motivos do alto índice de evasão escolar dos jovens pertencentes à zona rural.

Com o objetivo de atender à carência de conhecimentos técnicos da população rural foi criado o curso profissionalizante de técnico-agrícola. Entretanto, a prioridade dessas escolas tem sido preparar técnicos para prestarem serviços às grandes empresas, privadas ou públicas, ou para prosseguirem seus estudos em nivel superior. O tipo de educação que os jovens recebem nessas escolas não é suficiente para obter rendas razoáveis em suas propriedades, desestimulando-os a voltar ao campo (Peres et al.,1998).

A necessidade de dedicação em período integral aos estudos é outra dificuldade enfrentada pela juventude do meio rural. No campo, principalmente nas pequenas propriedades onde a produção é mais intensiva, existe a necessidade da mão-de-obra de todos os integrantes da família, mesmo dos filhos mais jovens. Este fator também pode explicar o alto nível de evasão e repetência no setor agrícola. Segundo o IBGE (Instituto Brasileiro de Geografia e Estatística), em 1990, somente 34,9\% dos jovens rurais de doze a quinze anos possuíam quatro ou mais anos de estudos no Brasil, ou seja, aproximadamente $65 \%$ dos jovens da zona rural abandonam a escola antes de completar as quatro séries consideradas fundamentais para a formação humana e profissional do indivíduo. Quando os jovens possuem pouco ou deficiente estudo tradicional, as conseqüências podem ser percebidas tanto no meio rural quanto no urbano. No campo, eles são pouco preparados para administrar seu próprio negócio e, portanto, dificilmente conseguem auferir lucros na agricultura. Quando se mudam para a cidade, é pouco provável que consigam se adaptar ao estilo de vida urbano, pois encontram barreiras educacionais e culturais que impedem seu avanço social. 
$\mathrm{Na}$ zona rural os problemas da educação são intensificados pelo fato de que os professores que lecionam nas suas escolas são pessoas da zona urbana sem qualquer conhecimento da realidade rural, que utilizam essas escolas apenas como uma forma de melhorar suas chances de emprego no setor urbano. Eles não têm um compromisso de vida com o campo e, portanto, não conseguem transmitir para os jovens o sentido de realização pessoal nas atividades rurais.

O extremo comodismo da sociedade na busca de soluções para os seus problemas é uma agravante da situação do ensino rural. No Brasil, todos os problemas de caráter social são deixados para o "governo" resolver e dificilmente a sociedade se organiza para combatê-los. Isso favorece a centralização do poder público, com o governo sempre assumindo uma postura paternalista diante das dificuldades sociais. Como uma das conseqüências, o sistema educacional público tornou-se excessivamente corporativista, impedindo uma participação mais ativa dos pais na formação de seus filhos. Segundo Peres et al. (1998), isto leva os pais a desenvolver um sentimento de inutilidade, acostumando-os a aceitar todas as decisões vindas das corporações de professores ou dos órgãos centrais pertencentes ao governo, comprometendo seu papel na educação dos filhos.

Durante décadas (1930 até final dos anos 70), a população do meio rural foi motivada a migrar para os centros urbanos em decorrência de políticas governamentais que afetavam prejudicialmente o setor. De acordo com Peres (1997), as três políticas que mais contribuíram para isso foram: 1) taxação das exportações no período, formadas quase só por produtos do setor primário; 2) supervalorização da taxa de câmbio, dificultando as exportações brasileiras e privilegiando as importações de máquinas e equipamentos industriais; e 3) tabelamento dos preços dos produtos agrícolas, principalmente daqueles usados como bens de salários. A contrapartida de ajuda do poder público com subsídios e preços mínimos só atingiu uma pequena parte da população rural e não impediu a migração em massa para os centros urbanos. $O$ auxílio 
governamental não beneficiou igualmente todos os membros do setor, contribuindo para a dicotomização da agricultura em dois setores: um moderno e rentável e outro tradicional e de baixa renda.

Atualmente, as razões que favorecem a migração são decorrentes do diferencial de renda entre os setores. As empresas urbanas (transformação e serviços), por atuarem num ambiente menos competitivo que as empresas do setor rural, tendem a auferir lucros mais altos. As novas tecnologias criadas para o setor rural são cada vez mais poupadoras de mão-de-obra. Assim, fatores de produção humanos e monetários tendem a ser cada vez mais atraídos para os centros urbanos. A possibilidade de a migração resolver os problemas gerados pela desigualdade de renda entre os setores urbano e rural é facilmente rejeitada, pois as cidades não possuem empregos nem infra-estrutura suficientes para absorver os migrantes.

Diante dessa problemática, o CEETEPS (Centro Estadual de Educação Tecnológica Paula Souza) e o Projeto UNIR (Uma Nova Iniciativa em Desenvolvimento Rural) juntaram-se em busca de uma solução. O Projeto UNIR sempre buscou, dentro de seus objetivos, contribuir para a melhoria da qualidade de vida de pequenos agricultores e trabalhadores rurais, preparar estudantes universitários para o trabalho em comunidades carentes e capacitar as instituições locais para a melhoria da qualidade dos serviços oferecidos. Da mesma forma, o CEETEPS, dentro de sua concepção de prover ensino profissionalizante e na tentativa de atender às necessidades da sociedade, encontrou na proposta do PROJOVEM a oportunidade de atenuar a carência de alternativas profissionalizantes para os jovens, filhos de pequenos produtores, trabalhadores e parceiros rurais, normalmente excluídos do sistema de ensino regular. 


\subsection{O Programa de Formação de Jovens Empresários Rurais}

Em 1995 iniciaram-se as primeiras discussões sobre a criação de um programa educacional capaz de viabilizar a pequena produção rural no Estado de São Paulo. Uma equipe formada por profissionais ligados ao Projeto UNIR (Uma Nova Iniciativa em Desenvolvimento Rural)/ESALQ, ao Centro Estadual de Educação Tecnológica Paula Souza (CETEEPS), ex-participantes do Programa Paulista de Lideranças Rurais (LIDERUSP) e representantes de comunidades rurais visitaram outros países e Estados brasileiros em busca de programas realizados com este propósito. Foi feita uma análise dos pontos fortes e fracos e, da junção destas experiências com a percepção das necessidades das pequenas propriedades rurais, surgiu o PROJOVEM.

O Programa de Formação de Jovens Empresários Rurais é destinado principalmente aos filhos de pequenos produtores rurais, proprietários ou não, que demonstram vocação para a agricultura ou à prestação de serviços às comunidades rurais, isto é, que pretendem se desenvolver econômica, social e culturalmente sem sair das áreas rurais. Mas que, por motivos financeiro (baixa renda), educacional (maioria não terminou o $1^{\circ}$ grau) ou por serem mão-de-obra necessária na propriedade, não conseguem freqüentar uma escola agrotécnica ou um curso superior ligado à agropecuária. Esses filhos de pequenos proprietários, parceiros ou trabalhadores, deficientes em capital físico e financeiro e com baixo nível de capital humano, dificilmente conseguem desenvolver seu próprio negócio e, com isso, auferir rendas razoáveis na agricultura. A saída freqüentemente encontrada por estes jovens é a migração para as cidades em busca de empregos, contribuindo para o colapso da infra-estrutura urbana (problemas de moradia, educação, saúde, fome, etc.).

A modernização tecnológica do setor agrícola tem se desenvolvido na direção de novas técnicas que minimizam a utilização de mão-de-obra, o que tende a agravar a situação de desemprego rural. A única alternativa para manter estes jovens no campo, diante das 
novas tendências ${ }^{5}$, é estimular sua capacidade administrativa, tornando-os capazes de gerir seu próprio negócio. Portanto, o objetivo do programa é formar "empresários" e não empregados. De acordo com a visão de seus idealizadores, a finalidade do PROJOVEM é "preparar estes jovens para administrarem atividades rurais, competitivamente e de maneira sustentada, garantindo níveis crescentes de renda para suas famílias" (Peres et al., 1998, p.13). O programa possui duração mínima de três anos, período considerado satisfatório para a formação de cidadãos-empresários capazes de elaborar e administrar um projeto de investimento. O jovem, para participar do programa, deve possuir de catorze a vinte e um anos, ser alfabetizado e desejar ser empresário em atividades ligadas à área rural. Além disso, deve possuir algum tipo de laço com a terra para desenvolver seu projeto, não precisando ser necessariamente proprietário. O programa não confere ao jovem nenhum tipo de certificado ou diploma de conclusão, pois entende que o jovem como empresário (dono de seu empreendimento) não precisa de documentos para provar sua competência. Atualmente, o programa é composto por nove núcleos espalhados pelo interior do Estado de São Paulo, todos vinculados às escolas agrícolas que se dispuseram a apoiar o PROJOVEM. O Quadro 1 sintetiza algumas informações sobre cada um dos núcleos que compõem o PROJOVEM.

\footnotetext{
${ }^{5}$ Estas novas tendências são causadas pela reestruturação produtiva através da adoção de novos equipamentos e modelos de organização empresarial que aumentam a produtividade e restringem cada vez mais a utilização de mão-de-obra.
} 


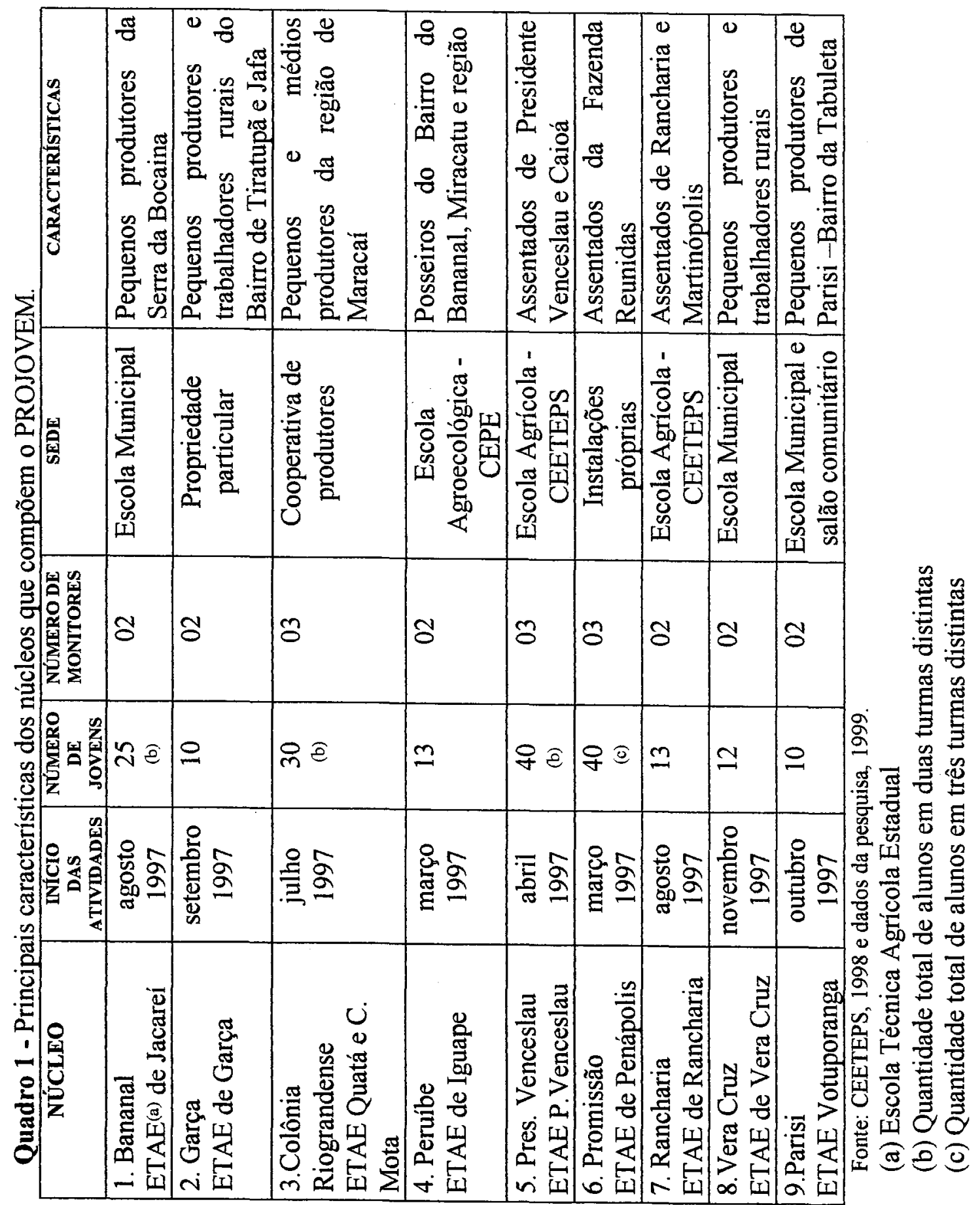


O programa possui uma forma de ensino não-convencional apoiado num tripé pedagógico capaz de dar sustentação sólida e eficaz às suas finalidades. Este suporte é formado pela pedagogia de alternância, "construtivismo" e projeto individual de investimento.

A pedagogia de alternância foi desenvolvida inicialmente por agricultores franceses na década de 30. Estes agricultores buscavam uma alternativa de ensino para seus filhos que conciliasse a aprendizagem sócio-profissional com o ensino recebido em sala de aula. Esta pedagogia permite o funcionamento do PROJOVEM de forma barata, eficiente e desburocratizada, pois possibilita que o jovem não se afaste do seu meio e conta com o importante envolvimento dos pais na formação de seus filhos. Com ela, os jovens alternam seu aprendizado entre o núcleo (onde aprendem matemática, biologia, química, etc.) e sua propriedade (onde aplicam o que aprenderam em aula), impedindo uma separação entre eles e suas famílias e o envolvimento deles com uma realidade que não lhes pertencem, que poderá culminar no êxodo juvenil do campo. Segundo Malassis (1975), citado por Werthein \& Bordenave (1981, p.37), educação e modernização rural devem caminhar juntas: "se a modernização da vida rural não caminha no mesmo ritmo do desenvolvimento educacional, é inevitável que isto acelere o êxodo rural, uma vez que a educação aparece aos olhos do interessado como o único meio de valorizar sua formação, melhorar sua renda e transformar seu modo de vida".

A outra base de sustentação da metodologia de ensino deste programa é o construtivismo. A concepção construtivista de ensino desperta no jovem a curiosidade por aprender sempre mais. Os jovens buscam, juntamente com os monitores, descobrir respostas às dúvidas e necessidades surgidas na realidade do dia-a-dia rural, construindo seu próprio conhecimento. 
O desenvolvimento do projeto de investimento é o eixo do processo de aprendizagem do PROJOVEM, pois todo o trabalho pedagógico (leituras, raciocínio matemático e conhecimentos interdisciplinares em geral) será realizado de acordo com o interesse e as necessidades dos jovens surgidas ao longo do período de elaboração e implantação do projeto. A execução dos projetos passará por todas as etapas da atividade, desde o planejamento, aquisição de empréstimos, obtenção e implantação de insumos, até a comercialização da produção e pagamento das dívidas (Peres et al., 1998). Entretanto, como a maioria dos jovens atendidos pelo PROJOVEM é carente, para possibilitar a implantação do projeto de investimento está sendo criado um Fundo Rotativo de crédito com recursos fornecidos pelo Banco Nacional de Desenvolvimento Econômico e Social (BNDES). O crédito é liberado ao jovem após a aprovação do projeto pela Associação Central de Pais do PROJOVEM (ACP). As condições de pagamento deste financiamento são semelhantes às de um banco comum e deste pagamento, depende a permanência da rotatividade do Fundo.

Os monitores responsáveis pela capacitação dos jovens são escolhidos pelos pais e contratados pelo CEETEPS por um período de dois anos, quando são obrigatoriamente afastados por um período mínimo de 6 meses (interstício) podendo ser recontratados depois. Para serem capazes de trabalhar dentro da linha proposta pelo programa, os monitores são treinados para orientar os jovens na busca de respostas às suas necessidades e de novos conhecimentos. A cada três meses são realizados encontros de reciclagem com a presença dos monitores de todos os núcleos e a Assessoria. A Assessoria da Associação Central de Pais do PROJOVEM, formada por profissionais da ESALQ/USP, do CEETEPS e por voluntários do ex- Projeto UNIR, é responsável pelo treinamento.

A elaboração de um projeto de investimento que atinja seu objetivo de proporcionar retornos dá ao indivíduo, além do lucro, reconhecimento social, facilitando sua integração à comunidade. Como se pode perceber, a missão do PROJOVEM vai além 
do processo de aprendizagem. A sua preocupação estende-se ao desenvolvimento individual e social do jovem.

O programa, apesar de ter sido implantado por meio de uma parceria entre o Projeto UNIR/USP e o CEETEPS, pertence à comunidade. Cada núcleo de aprendizagem é administrado por uma Associação de Pais que faz parte de uma Associação Central responsável, juntamente com o CEETEPS, pela manutenção e continuidade das atividades do programa. Cabe à Associação local conseguir acomodações para os estudantes no período de aulas, escolher os monitores, conseguir transporte para os jovens chegarem até o núcleo, providenciar alimentos para o preparo das refeições e conseguir um mínimo de material didático e uma sala de aula. $\mathrm{O}$ apoio do CEETEPS dáse através do financiamento dos salários e do transporte dos monitores e cozinheiros $\mathrm{e}$ de treinamento deste pessoal e dos pais.

Como se trata de um programa diferenciado, para a preservação de suas especificidades foi criada uma identidade própria definida por uma linha básica seguida por todos os núcleos. Esta linha foi criada com base na prática obtida desde o momento da implantação do programa, na experiência de outros e nas necessidades da clientela atendida, visando preservar as características de uma escola comprometida com a capacitação do jovem rural carente.

\section{-Programa:}

metodologia mínima: pedagogia da alternância, elaboração e implementação de um projeto de investimento, planejamento estratégico da empresa;

- duração mínima: três anos, objetivando a formação de cidadãos-empresários;

- alvo: voltado para o atendimento das necessidades individuais e de desenvolvimento do jovem, e

- foco: enfatiza o aprendizado a partir da prática e da vivência profissional. 
-Jovem:

tem entre catorze e vinte e um anos de idade, com exceções sob responsabilidade da Associação de Pais;

- tem acesso aos recursos naturais necessários para desenvolver seu projeto;

quer ser empresário rural. É alfabetizado e sabe as quatro operações matemáticas básicas, e

ade estudar em escolas noturnas, desde que retorne ao núcleo para pernoitar.

-Pais:

co-responsáveis pela educação do filho, comprometido com a sua orientação na propriedade, e

membros da Associação de Pais e nela atuantes;

-Associação de Pais:

- é a dona e administradora do núcleo;

- viabiliza e dá sustentação ao trabalho do núcleo e é atuante na educação dos jovens;

- filiada à Associação Central do PROJOVEM, é soberana e legalmente responsável pelo núcleo;

pode possuir membros que não sejam pais de jovens participantes do programa, mas que tenham interesse no desenvolvimento da comunidade local;

em questões diretamente ligadas aos jovens, decidem os membros que têm filhos no programa, e

assume a presente linha básica do PROJOVEM.

-Monitor:

escolhido pela Associação de Pais;

- procura sempre capacitar-se para melhorar seu desempenho;

É agente facilitador e orientador do aprendizado do jovem e aprende junto com ele;

- convive no núcleo dia e noite, e 
- deve ser da área de Ciências Agrárias e ter disponibilidade de dedicação mínima de 40 horas semanais.

-Atividades Curriculares e Material Didático:

meios: a utilização de bibliotecas é fundamental;

- objetivo: todas as ações e recursos são voltados para que o jovem aprenda a buscar conhecimentos e informações, e

- princípios teóricos são essenciais para a compreensão e descrição dos fenômenos práticos;

-Recursos Financeiros:

existência de um Fundo Rotativo para financiar os projetos de investimentos dos jovens, sob a responsabilidade da Associação de Pais, preferencialmente gerido por uma instituição financeira, e

- a Associação de Pais é responsável pela captação dos recursos, inclusive os do Fundo Rotativo.

-Associação Central:

dá apoio jurídico, é fonte de atualização pedagógica e zela pelos princípios do PROJOVEM;

- ajuda a viabilizar recursos externos e legitima novos núcleos, e

- decide sobre as aplicações do Fundo Rotativo, quando os recursos são conseguidos por ela.

-CEETEPS E ESALQ:

parceiros da Associação Central e das Associações de Pais, e

- função: ajudam a viabilização de contratação de monitores e na sua capacitação permanente. 
Em resumo, a tendência provocada pelas forças de mercado aponta para uma crescente migração rural-urbana, famílias de pequenos agricultores dificilmente sobreviverão com técnicas rudimentares às exigências do mercado e à competição imposta pela abertura econômica. Nos centros urbanos a situação não será diferente. Com o mercado de trabalho exigindo cada vez mais mão-de-obra especializada, os trabalhadores de baixa qualificação advindos do campo vão se juntar à massa de desempregados ou de trabalhadores informais, agravando os problemas sociais sofridos pelas cidades. A solução mais viável para este problema requer maciços investimentos em capital humano, fator subdesenvolvido no meio agrícola brasileiro. 
Alfred Marshall

\section{TEORIA DO CAPITAL HUMANO}

Num período de transformações sociais, econômicas, tecnológicas e políticas, uma das características dessa fase é a discussão acerca do papel da educação no desenvolvimento. Esta preocupação sempre existiu, mas ganhou maior destaque a partir da década de 60. Antes disso, a maioria dos países subdesenvolvidos priorizava o desenvolvimento baseado na industrialização, ou seja, no investimento em capital físico (fábricas e máquinas que produziam renda sob a forma de produção de bens e serviços) capaz de promover políticas de substituição de importações (Werthein \& Bordenave, 1981).

Adam Smith, em 1776, já havia apontado em A Riqueza das Nações a analogia existente entre educação e investimento em capital fixo:

Um homem educado à custa de muito tempo e trabalho para um qualquer desses empregos em que se requer uma extraordinária habilidade e destreza pode ser comparado a uma dessas máquinas caras; o trabalho que aprende a efetuar e que será pago por salários mais altos do que os dos empregos vulgares deverá repor toda a despesa da sua educação de uma forma que corresponda pelo menos aos lucros normais de um capital igualmente valioso (Smith, 1974, p.90).

Passou-se muito tempo até que se reconhecesse o valor econômico da educação. $\mathrm{Na}$ década de 60 surgiram os primeiros estudiosos a combater a idéia equivocada de que $o$ 
investimento em capital físico era o maior responsável pelo crescimento econômico. Grandes economistas, entre eles Gary Becker (1993), Theodore Schultz (1973) e Jacob Mincer (1974), mostraram que os gastos em educação, treinamento, saúde e migração deveriam ser considerados investimentos, tanto pelas empresas como pelos paises, produzindo benefícios futuros na forma de aumento da produtividade e, conseqüentemente, da renda para os indivíduos educados e para a sociedade como um todo.

Schultz foi o primeiro autor a utilizar a expressão capital humano na literatura econômica ${ }^{6}$. No início houve muita resistência por parte de alguns economistas em aceitar o conhecimento e as habilidades dos indivíduos como sendo uma forma de capital. Em parte, essa resistência foi promovida por problemas relacionados à moral, pois muitos consideravam o investimento em seres humanos algo ofensivo, que contrariava os costumes da sociedade moderna. Schultz (1973) justifica a utilização do termo argumentando que "é humano porque se acha configurado no homem, e é capital porque é uma fonte de satisfações futuras, ou de futuros rendimentos, ou ambas as coisas" (p.53). O interesse de Schultz por capital humano surgiu da observação de que os níveis de riqueza e pobreza entre os agricultores americanos estavam intensamente ligados à educação e fecundidade (Bowman, 1980). Na sua visão macroeconômica, recursos físicos, naturais e mão-de-obra bruta não seriam suficientes para incentivar o desenvolvimento de economias. Seria necessário investimentos em aptidões humanas para 0 aumento da produtividade.

Para Becker (1993), o investimento em capital humano pode ser entendido como o empenho do agente econômico em aumentar sua escolaridade, seu treinamento em qualquer área do conhecimento, ou seja, qualquer atividade que eleve seu conjunto de habilidades e, com isso, sua capacidade produtiva. Estas habilidades produtivas,

\footnotetext{
"A expressão capital humano foi usada pela primeira vez no artigo "Investindo em Capital Humano", publicado na American Economic Review, v.51, march 1961.
} 
adquiridas através da experiência e aprendizagem, podem ser encaradas como um bem de capital humano. Desta forma, o indivíduo que investe em capital humano espera receber uma renda futura maior do que se não tivesse realizado o investimento. $\mathrm{O}$ agente econômico tem de estar disposto a aumentar sua qualificação abdicando da renda oriunda de seus anos de juventude, período em que passa se educando e treinando, para garantir uma renda futura mais alta.

Além de aumentar a capacidade produtiva e o rendimento dos indivíduos, o investimento em educação ou qualquer outro tipo de acumulação de capital humano gera uma grande externalidade positiva ${ }^{7}$, resultante da união do saber de diversos indivíduos que investiram em capital humano, produzindo um montante de conhecimento superior ao individual que é transmitido, direta ou indiretamente, a todas as outras pessoas. De acordo com Barros \& Mendonça (1997), este tipo de externalidade é de difícil avaliação, mas mesmo assim seus efeitos são considerados superiores aos efeitos privados da educação ${ }^{8}$.

Gary Becker (1993) admite no seu estudo sobre a teoria do capital humano que alguns tipos de conhecimentos são melhor atingidos quando combinados à prática, outros exigem um maior tempo de dedicação e estudos. De acordo com Becker "A maior parte do treinamento na indústria da construção civil é melhor realizado no local do próprio trabalho, enquanto que o treinamento de físicos necessita de um grande período de estudo especializado" (Becker, 1993, p.51). A educação nas escolas e no trabalho são, até um certo nivel, complementares, dependendo do tipo de trabalho e da quantidade de conhecimento formal possuída pelo trabalhador.

\footnotetext{
7 Externalidade positiva ocorre quando uma atividade de mercado concede beneficios a agentes econômicos que não estão diretamente envolvidos na atividade (Byrns, R. \& Stone G., Microeconomia, 1996 , p. 557)

${ }^{8}$ Entende-se por efeitos privados da educação os resultados de investimentos em educação que influenciam as condições de vida daqueles que se educam, como elevação dos salários via aumentos de produtividade.
} 
$\mathrm{O}$ aumento nos rendimentos adquiridos pelo investimento em capital humano tende a decrescer com o nível de experiência do trabalhador. Isto está de acordo com a Teoria do Ciclo de Vida ${ }^{9}$ desenvolvida por Franco Modigliani na década de 50. Modigliani enfatizou que a renda do indivíduo varia sistematicamente ao longo da vida, sendo maior nos períodos produtivos, no qual o indivíduo poupa para manter o mesmo padrão de vida nos momentos de escassez ou de aposentadoria. Os estudos realizados sobre a depreciação do capital humano mostram uma relação entre experiência e rendimentos na forma côncava de $U$ invertido, mostrando que os rendimentos aumentam a taxas decrescentes de acordo com os anos trabalhados. Isso significa que, a partir de certo ponto, os rendimentos dos indivíduos passam a decrescer, indicando um processo de obsolência e depreciação à medida que o trabalhador envelhece e perde algumas de suas qualificações e habilidades. De acordo com essa hipótese, pode-se representar graficamente a relação entre rendimento e experiência (figura 1).

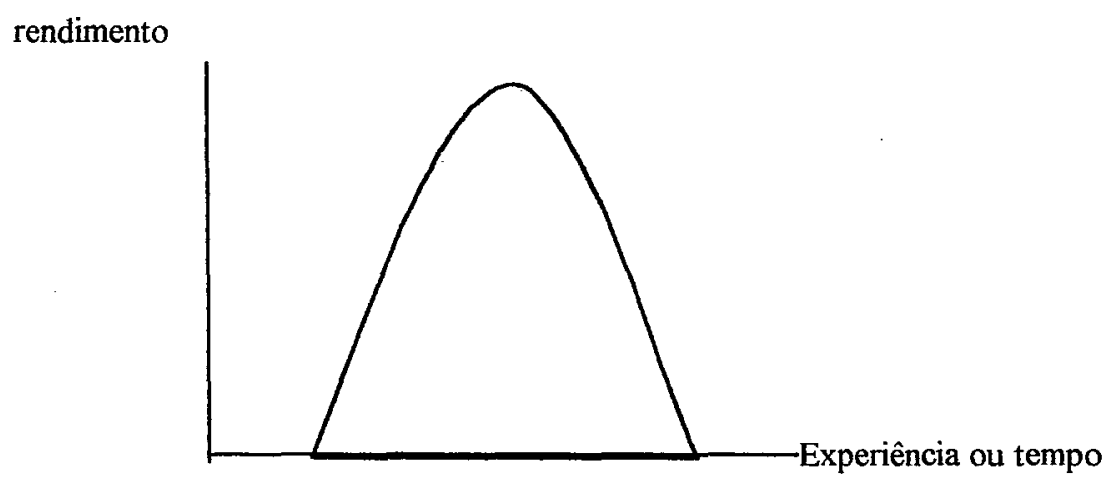

Figura 1: Evolução da renda ao longo da vida de um indivíduo.

A partir da década de 60, com o desenvolvimento da Teoria do Capital Humano, houve uma crescente preocupação com os métodos de se mensurar o retorno advindo dos investimentos em educação. Análises de custo-benefício têm sido aplicadas à educação para comparar o custo total da educação (para o indivíduo ou para a sociedade) com o

\footnotetext{
${ }^{9}$ Para maiores detalhes ver MANKIW, N. G. Macroeconomics. $3^{\text {a }}$ edition, 1997 , p. 420 e ABEL, A. B. \& BERNANKE, B.S. Macroeconomics, $2^{\mathrm{a}}$ edition, 1995, p. 265.
} 
retorno esperado dos investimentos feitos em educação ou treinamento. As técnicas mais utilizadas para esta finalidade são os modelos desenvolvidos por Becker (1993) e Schultz (1973), que calculam o retorno social, e o de Mincer (1974), que calcula o retorno privado aos investimentos em educação. A taxa de retorno social é uma tentativa de medir o benefício líquido do investimento em educação para a sociedade como um todo. Enquanto, a taxa de retorno privado mede o benefício da educação apenas para o indivíduo que se educa. Quanto aos custos, os custos sociais são diferentes dos custos privados devido à educação ser, em grande parte, financiada pelo Estado.

Muitos economistas defendem o investimento em educação como mais rentável que os investimentos realizados em capital físico. Na opinião de Becker (1993), educação e treinamento são os mais importantes investimentos em capital humano, produzindo retornos mais altos que os retornos aos investimento em capital fixo.

O modelo de capital humano, desenvolvido por Mincer (1974) para a determinação dos rendimentos advindos da educação, é largamente utilizado em trabalhos econométricos. De acordo com este modelo, o rendimento é função do número de anos de escolaridade dos indivíduos, dos anos de experiência no mercado de trabalho e de outros fatores que podem influir nos rendimentos, como raça, gênero, setor econômico, região e outros. $\mathrm{O}$ modelo assume os anos de educação formal como o fator responsável pelas diferenças de rendimentos entre os indivíduos. $O$ indivíduo que investe um ano em educação, durante o período de 0-1, receberá um rendimento $Y_{1}$, maior que o salário inicial $Y_{0}$ de um indivíduo que não investiu em educação. A taxa de retorno advinda de um ano de educação é dada por:

$$
r_{1}=\frac{Y_{1}-Y_{0}}{Y_{0}}
$$


onde $r_{1}$ é a taxa de retorno do investimento de um ano em educação, $Y_{1}$ é o rendimento após um ano de estudo e $Y_{0}$ os rendimentos sem a escolaridade. A equação (1) pode ser reescrita como:

$Y_{1}=Y_{0}\left(1+r_{1}\right)$

Da mesma forma, a taxa de retorno obtida após dois anos de estudos é:

$$
Y_{2} \equiv Y_{1}\left(1+r_{2}\right) \equiv Y_{0}\left(1+r_{1}\right)\left(1+r_{2}\right)
$$

Generalizando para S anos de escolaridade, tem-se:

$Y_{s}=Y_{0}\left(1+r_{1}\right)\left(1+r_{2}\right) \ldots\left(1+r_{s}\right)$

Considerando $r_{1}=r_{2}=\ldots=r_{s}$, ou seja, que a taxa de retorno à escolaridade seja a mesma para todos os níveis de escolaridade, tem-se:

$Y_{s}=Y_{0}\left(1+r_{s}\right)^{s}$

Aplicando logaritmo sobre a equação (4), tem-se:

$$
\ln Y_{s}=\ln Y_{0}+S \ln \left(1+r_{s}\right)
$$


Para valores muito pequenos, $\ln \left(1+r_{s}\right) \cong r_{s}$, e adicionando as perturbações aleatórias a fim de tornar a relação probabilística ${ }^{10}$, tem-se a equação de rendimentos proposta por Mincer (1974):

$\ln Y_{s}=\ln Y_{0}+r_{s} S+\mu_{i}$

Entretanto, é importante ressaltar que o modelo de Mincer (1974) para a estimativa da taxa de retorno não considera os custos diretos da educação (custos correntes das escolas e alunos e custos de capital). Além disso, omite as externalidades positivas causadas pela educação.

Becker (1993) e Schultz (1973) também desenvolveram um método capaz de calcular a taxa de retorno dos investimentos em educação, amplamente utilizado em estudos sobre este assunto. Este método consiste em mensurar a taxa de retorno dos investimentos por meio de estimativas de uma taxa de desconto que iguale os valores presentes dos custos e dos benefícios, ou seja, a taxa interna de retorno.

O modelo de Becker será apresentado de forma sucinta e simplificada, buscando dar idéia do significado do cálculo da taxa de retorno aos investimentos em educação. Para isso, será utilizado um modelo hipotético que assume o investimento restrito a um único período e os retornos para todos os períodos remanescentes. Considere $\mathrm{Y}$ uma atividade realizada por uma pessoa que acaba de iniciá-la (momento zero), recebendo um fluxo de rendimento líquido real ${ }^{11}$ de $Y_{0}$ durante o primeiro período, $Y_{1}$ no período seguinte $e$ assim por diante até $\mathrm{o}$ último período, $\mathrm{Y}_{\mathrm{n}}$.

\footnotetext{
${ }^{10}$ Isto é, a fim de refletir o fato que, no mundo real, as relações entre as variáveis econômicas são inexatas e, algumas vezes, erráticas.

${ }^{11}$ Rendimentos líquidos significam rendimentos brutos durante algum período menos os custos de instrução durante o mesmo período. Rendimento real refere-se à soma dos ganhos monetários e o equivalente monetário de rendimentos mentais.
} 
Supondo duas atividades:

Atividade $\mathrm{Y} \rightarrow$ exige investimento educacional no período inicial $\left(\mathrm{t}_{0}\right)$.

Atividade $\mathrm{X} \rightarrow$ não exige investimento.

O valor presente do fluxo de rendimentos líquidos da atividade $\mathrm{Y}$ é dado por:

$\mathrm{V}(\mathrm{Y})=\sum_{j=0}^{n} \frac{Y_{j}}{(1+i)^{j+1}}$

onde $i$ é a taxa de juros de mercado, assumida constante para todos os períodos. X é uma outra atividade que produz um fluxo de rendimento líquido de $\mathrm{X}_{0}, \mathrm{X}_{1}, \ldots, \mathrm{X}_{\mathrm{n}}$, com valor presente de $\mathrm{V}(\mathrm{X})$ :

$\mathrm{V}(\mathrm{X})=\sum_{j=0}^{n} \frac{X_{j}}{(1+i)^{j+1}}$

O valor presente do ganho por escolher Y seria dado por:

$\mathrm{d}=\mathrm{V}(\mathrm{Y})-\mathrm{V}(\mathrm{X})=\sum_{j=0}^{n} \frac{Y_{j}-X_{j}}{(1+i)^{j+1}}$

A equação (10) pode ser reformulada para trazer explicitamente a relação entre custos e retornos. O custo de se investir em capital humano iguala-se aos rendimentos líquidos advindos dessa escolha. Se a atividade $\mathrm{Y}$ requer investimento somente no período inicial e se $X$ não requer nenhum, o custo de se escolher $Y$ em vez de $X$ é simplesmente a 
diferença entre seus rendimentos líquidos no instante inicial e o retorno total seria o valor presente das diferenças entre os rendimentos líquidos em períodos posteriores. Se $\mathrm{C}=\mathrm{X}_{0}-\mathrm{Y}_{0}, \mathrm{~K}_{\mathrm{j}}=\mathrm{Y}_{\mathrm{j}}-\mathrm{X}_{\mathrm{j}}, \mathrm{j}=1, \ldots, \mathrm{n}$, e se $\mathrm{R}$ mede o retorno total, o ganho de $\mathrm{Y}$ seria escrito como:

$\mathrm{d}=\sum_{j=1}^{n} \frac{K_{j}}{(1+i)^{j}}-\mathrm{C}=\mathrm{R}-\mathrm{C}$

A relação entre custos e retornos pode ser derivada de uma forma diferente e, para nossos propósitos, mais simples de se definir: a taxa interna de retorno. Ela é, simplesmente, a taxa de desconto que iguala o valor presente dos retornos ao valor presente dos custos. Em outras palavras, a taxa interna de retorno, r, é definida implicitamente por:

$\mathrm{C}=\sum_{1}^{n} \frac{K_{j}}{(1+r)^{j}}$

o que claramente implica:

$\sum_{j=0}^{n} \frac{Y_{j}}{(1+r)^{j+1}}-\sum_{0}^{n} \frac{X_{j}}{(1+r)^{j+1}}=\mathrm{d}=0$

desde que $\mathrm{C}=\mathrm{X}_{0}-\mathrm{Y}_{0}$ e $\mathrm{K}_{\mathrm{j}}=\mathrm{Y}_{\mathrm{j}}-\mathrm{X}_{\mathrm{j}}$. Portanto, a taxa interna de retorno é também a taxa de desconto que iguala o valor presente dos rendimentos líquidos. Esta equação poderia ser consideravelmente simplificada se os retornos fossem os mesmos em todos os períodos, ou $Y_{j}=X_{j}+K, j=1, \ldots, n$. Com isso, a equação (11) tornar-se-ia: 
$C=\frac{K}{r}\left[1-(1+r)^{-n}\right]$

onde $(1+r)^{-n}$ é a correção para o tempo de vida de uma pessoa, que tende a zero à medida que os anos passam. Portanto, se investimento é restrito a um único período, custos e taxas de retorno são facilmente determinados de informações sobre rendimentos líquidos. Entretanto, este método apresenta dois problemas: primeiro, a taxa de retorno social é subestimada, pois não considera a grande externalidade positiva da educação; e, segundo, os resultados encontrados são muito sensíveis, pois como existem inúmeras maneiras (nenhuma completamente correta ou incorreta) de serem apropriados os custos, as taxas de retorno variam muito (Leal \& Werlang, 1991).

Por fim, o investimento em capital humano, e especialmente em educação, apresentamse como necessidade imposta pelos avanços tecnológicos. Por isso, a preocupação em se aperfeiçoar as técnicas de mensuração não cessam. Os métodos pioneiros de Mincer e Becker evoluíram com a introdução de novos modelos e técnicas (programas computacionais), mas continuam sendo a base para o cálculo do benefício da educação sobre o desenvolvimento pessoal, social e econômico de um indivíduo ou de uma nação. 
"An investment in knowledge

pays the best interest".

Benjamin Franklin

\section{REVISÃO DE LITERATURA}

A importância da educação na eficiência produtiva tem sido intensamente debatida em trabalhos sobre desenvolvimento econômico. Estudos sobre crescimento econômico têm mostrado que, nos países desenvolvidos, o aumento no produto não pode ser completamente explicado apenas pelo aumento quantitativo no uso dos insumos físicos e pelo aumento da população trabalhadora. Solow (1957) sugeriu que essa "diferença residual" do crescimento econômico pode ser atribuída a um aumento na produtividade dos recursos devido às inovações técnicas e à utilização de novos processos de produção e organização. Inicialmente a literatura atribuiu toda a diferença a novas tecnologias ou ao progresso técnico. Só com Schultz ela foi dividida entre progresso técnico e novos investimentos ao capital humano. Assim, os fatores responsáveis por essas "diferenças residuais" estão intimamente ligados à educação.

Os efeitos do investimento em educação ou em qualquer outro tipo de capital humano dependem do nível de desenvolvimento da região a ser beneficiada. $\mathrm{O}$ retorno à educação diminui à medida que se compara regiões ricas com regiões pobres e setor urbano com o setor rural. Ilha \& Lima (1989) consideram que o impacto provocado pelo investimento em educação é diferente para cada fase de crescimento, portanto, os argumentos que são válidos para evidenciar o alto valor econômico da educação nas regiões desenvolvidas não servem para justificá-lo nas regiões menos desenvolvidas. Neste sentido, Kassouf (1996), através de um estudo desagregado sobre as diferenças nos retornos à educação e treinamento entre os setores urbano e rural do Brasil, estimou funções de rendimentos através dos dados da Pesquisa Nacional sobre Saúde e Nutrição - 1989. Para obtenção de parâmetros consistentes, a autora utilizou o instrumental 
econométrico proposto por Heckman (Econometrica, v. 45, n.1, p. 153-161, jan. 1979) que permite correção da seletividade da amostra, para depois calcular os retornos. $\mathrm{O}$ estudo concluiu que os retornos à educação e treinamento foram bem maiores no setor urbano que no setor rural, sendo que os trabalhadores urbanos atingem um pico de rendimento, em média, sete anos mais cedo que os trabalhadores do setor rural. Um dos prováveis motivos para essa diferença pode estar relacionado à educação desvinculada da realidade rural oferecida aos jovens deste meio.

Em estudo sobre retornos à educação no Brasil realizado para o período de 1976-89, Leal \& Werlang (1991), utilizando dados da PNAD (Pesquisa Nacional de Amostras por Domićlí) e aplicando o método de estimativas proposto por Mincer (1974), que calcula a taxa de retorno pessoal ${ }^{12}$ da educação, encontraram elevadas taxas de retornos à educação. Isto provavelmente ocorreu porque o método de Mincer não considera os custos com educação em seu cálculo, o que torna o retorno muito mais alto. Além disso, a amostra selecionada para o estudo era formada por trabalhadores residentes em áreas metropolitanas que possuem maiores oportunidades de investir em capital humano e com idade entre 25 e 50 anos, faixa etária de grande potencial produtivo, o que contribui para elevar a taxa de retorno.

Tanto o trabalho de Kassouf (1996) quanto o de Leal \& Werlang (1991) mostram os efeitos positivos da educação para a economia como um todo. Contudo, o trabalho de Kassouf (1996) confirma que o retorno aos investimentos em educação é maior nas áreas urbanas, regiões mais desenvolvidas que o meio rural brasileiro.

Mesmo admitindo uma maior eficiência nos setores mais modernos da economia, a educação no meio rural tem uma função extremamente importante no desenvolvimento

\footnotetext{
${ }^{12}$ A taxa de retorno pessoal, diferentemente da taxa de retorno proposta por Becker (1993) e Schultz (1973), não inclui os impostos pagos (pelo lado dos beneficios) e os custos da educação (professores, manutenção, edificação etc.).
} 
do setor. Existem várias evidências empíricas que relatam a importância da educação na eficiência produtiva do setor agrícola. Lockheed et al. (1980) revisaram 18 trabalhos relacionados aos efeitos da educação sobre a produtividade em pequenas propriedades agrícolas em 13 países da Europa, África e América Latina. Para a realização desse estudo, os autores utilizaram várias fontes de dados, o que pode ter produzido algum viés em seus resultados. $O$ estudo concluiu que, na maioria dos casos, o efeito da educação foi positivo, mostrando que a cada 4 anos de educação formal, o aumento nos ganhos médios de produtividade atingem $7,4 \%$. Entretanto, não se pode esquecer que essas regiões, da mesma forma que o Brasil, apresentam características e potenciais naturais, econômicos e humanos bastante distintos entre si, podendo esta média oscilar para cima ou para baixo dependendo do estágio de desenvolvimento de cada uma.

Para Gisser (1965), a educação pode produzir dois efeitos diferentes no meio rural: efeito mobilidade e efeito capacitação. O primeiro diz respeito à expansão das opções de trabalho que o jovem adquire pelo aumento da escolaridade fora do setor agrícola. $\mathrm{O}$ segundo efeito é demonstrado pelo aumento das habilidades na execução de tarefas cotidianas pela adaptação a novas técnicas e por uma melhor alocação dos recursos disponíveis. Ele analisou o impacto produzido por uma elevação no nivel educacional da população rural sobre a migração rural-urbana nos Estados Unidos. Segundo o autor, o efeito produzido pela migração supera o aumento na produtividade provocado pelo efeito capacitação. $\mathrm{O}$ estudo concluiu que um aumento de $10 \%$ no nível de escolaridade no meio rural levaria a uma migração rural-urbana entre $6 \%$ e 7\%, aumentando o salário rural em torno de 5\%. Este aumento no salário é devido à intensificação da migração rural-urbana e conseqüente diminuição da quantidade de mão-de-obra rural.

Seguindo a mesma metodologia proposta por Gisser, Campos (1998) analisou as implicações da escolaridade no mercado de trabalho rural no Paraná nos anos de 1970, 1980 e no conjunto 1970-1980. O resultado desse trabalho mostrou uma associação positiva entre escolaridade e salário rural pelo lado da oferta, indicando que uma 
elevação no nível de escolaridade do indivíduo conduziu a maiores salários. Isso permite concluir que a escolaridade contribuiu para elevar as chances do trabalhador rural em encontrar emprego fora do setor agrícola nos anos de 1970 e 1980. Pelo lado da demanda, os empresários agrícolas mostraram-se indiferentes na contratação de trabalhadores com diferentes níveis de escolaridade, apontando que o efeito capacitação não ocorreu para os trabalhadores rurais do Paraná. Este estudo demonstra que, quando o nível de escolaridade dos jovens rurais aumenta, eles encontram maiores incentivos para buscar empregos urbanos, já que o efeito capacitação não fez diferença para os contratadores de mão-de-obra rural.

Welch (1970), assim como Gisser, vê dois efeitos produzidos pela educação no meio rural: 1) um nível maior de educação pode permitir ao agricultor produzir mais, mantidos constantes os outros recursos; e 2) um nível mais alto de educação pode aumentar a capacidade do produtor em adquirir e operacionalizar informações sobre novos insumos e custos, facilitando a aquisição de novos fatores de produção. Portanto, um aumento no nível educacional dos indivíduos do meio rural altera a eficiência produtiva, provocando o aprimoramento das funções administrativas, o aumento da produção, da produtividade do trabalhador e de seus rendimentos. Esses dois efeitos constatados por Welch são conhecidos, respectivamente, por efeito-trabalhador e efeitoalocativo. Welch, diferentemente de Gisser, não identificou o efeito mobilidade produzido pela educação.

Ilha \& Lima (1989) analisaram os efeitos da educação formal sobre a produção e produtividade em duas regiões diferentes quanto ao nivel de modernização do Estado de Minas Gerais. Através da utilização do modelo conceitual de Welch (1970), eles conseguiram a desagregação do impacto da educação em efeito-trabalhador (trabalho físico) e efeito-alocativo (administração). Os resultados mostraram que a educação contribuiu positivamente para o produto agrícola nas duas áreas. Entretanto, os efeitos "trabalhador" e "alocativo" só se mostraram totalmente positivos no meio moderno, 
sendo que o alocativo foi pouco representativo no meio mais carente, demonstrando que o tipo de educação oferecida à parcela mais pobre da população não atende às suas necessidades. Esse estudo mostra que, apesar das diferenças de efetividade produzidas pela educação no setor agrícola, os efeitos da educação são sempre positivos, demonstrando a necessidade do investimento em educação e treinamento para que a população rural compreenda e aloque de forma cada vez mais eficiente as novas tecnologias.

Para Grossi (1978), o caminho para se conseguir aumentar a renda na zona rural passa pela educação e modernização agrícola. Segundo este autor, não basta facilitar a aquisição de fatores modernos capazes de aumentar a produção por trabalhador e a produção por unidade de área. É preciso, antes disso, dar condições às populações rurais de obter novos conhecimentos e novas práticas necessárias ao desenvolvimento agrícola: "grande parte destes fatores modernos, cuja introdução pode transformar a produtividade rural, está na dependência de transformações de caráter educativo..."(Grossi, 1978, p. 2).

Analisando o efeito da educação sobre a renda, Barros \& Mendonça (1995) concluíram que a produtividade de um trabalhador reflete seu nível de qualificação. $\mathrm{Na}$ análise realizada por estes autores sobre os determinantes da desigualdade no Brasil, a qualificação foi apontada como a razão dos menores salários percebidos pelos trabalhadores menos qualificados e de os trabalhadores mais qualificados fazerem parte de um segmento do mercado mais moderno e com maior produtividade. Da mesma forma, o nível de conhecimento e habilidade do produtor rural pode caracterizar a amplitude das diferenças no resultado econômico das atividades agrícolas entre as propriedades de mesmas características.

Aqueles autores (Barros \& Mendonça, 1997) observaram em um outro trabalho que a distribuição de renda é mais igualitária nos países desenvolvidos devido às pequenas 
diferenças nos níveis educacionais, pois o excesso de trabalhadores qualificados exerce pressão para diminuição dos salários, enquanto a escassez de trabalhadores desqualificados pressiona os salários para cima, contribuindo para uma distribuição de renda mais justa. Entretanto, o Brasil contraria esta interpretação, pois o aumento do nível educacional é um dos grandes responsáveis pelo desnível de salários entre os trabalhadores e, conseqüentemente, pela má distribuição de renda da população (Barros \& Mendonça, 1995).

Mesmo conhecendo os benefícios advindos da educação, pouco tem sido feito para modificar o processo educacional no meio rural. A educação oferecida aos jovens rurais é a mesma oferecida aos jovens do setor urbano. Programas educacionais que atendam especificamente às necessidades dos jovens carentes residentes na área rural são escassos. Geralmente, programas deste tipo são iniciativas da própria sociedade ou de organizações não-governamentais preocupadas com as condições de vida de uma minoria. Para exemplificar, podemos citar a ação do Movimento Sem Terra (MST) em favor do ensino nos assentamentos rurais. De acordo com os dados (VEJA, n. 1459, 28/08/96, p. 68-74), existem nos assentamentos controlados pelo MST aproximadamente 38.000 alunos. Para atender a todas essas crianças e jovens, o Movimento dispõe de 1.500 professores, quase todos da rede pública de ensino. Além disso, o MST promove campanhas para a erradicação do analfabetismo, cursos de capacitação e mantém cursos de $2^{\circ}$ grau de magistério e técnico em cooperativismo.

Os princípios pedagógicos adotados pelo MST visam a combinação entre ensino e capacitação, segundo a realidade vivida pelos alunos. Além desse, outros princípios norteiam a pedagogia: a preocupação com problemas sociais, a educação para o trabalho, a relação entre educação, cultura e política, a administração democrática do ensino, a auto-organização dos estudantes e outros. O tipo de educação proposta pelo MST é uma maneira de impedir que os jovens se afastem da ideologia do Movimento. Segundo Menezes Neto (Revista Economia Rural, UFV, Viçosa (MG), ano 8, n.2, 1997), 
o MST formou uma escola unitária que busca superar o conhecimento geral e específico, técnico e político, humanista e técnico, teórico e prático, pois na sua concepção educacional, tudo se mistura na mesma realidade.

Outra proposta surgida por iniciativa da sociedade são as Casas Familiares Rurais (CFR), inspiradas no modelo francês das "Maisons Familiales Rurales". A pedagogia de alternância introduzida por este tipo de escola é uma alternativa educacional para os jovens que querem permanecer no campo e para a sobrevivência da pequena produção. Na opnião de Cogo (1994), a mecanização da agricultura foi a grande responsável pela expulsão do homem do campo, sendo que os pequenos produtores que ainda persistem na agricultura encontram enormes dificuldades para viabilizar sua produção. É nesse contexto que Cogo (1994) analisa as CFR de Barracão e Santo Antônio do Sudoeste (PR) como alternativas para a salvação da agricultura familiar.

Para a realização do seu estudo, Cogo (1994) utilizou entrevistas aplicadas a pais e jovens formados nas Casa Familiares Rurais de Barracão e Santo Antônio do Sudoeste durante 1990 e 1991. A pesquisa de campo teve por objetivo verificar a situação socioeconômica e as perspectivas das famílias depois que os jovens concluíram o aprendizado nas CFR. Os resultados mostraram que as CFR, apesar de proporcionar melhorias nas técnicas de produção nas pequenas propriedades, ainda não são capazes de solucionar os graves problemas dos pequenos agricultores. Isso porque a viabilização da agricultura familiar depende da introdução de novas técnicas produtivas, o que necessita de recursos fisicos e financeiros.

As CFR de Barracão e Santo Antônio do Sudoeste fazem parte da Associação Regional das Casas Familiares Rurais (ARCAFAR), que engloba as CFR existentes nos Estados do sul do País. Além dessa experiência, existem vários outros programas educacionais que utilizam a pedagogia da alternância inspirada no modelo francês das Casas Familiares Rurais. O mais antigo destes programas no Brasil é o MEPES (Movimento de 
Educação Promocional do Espírito Santo) no Espírito Santo. Essa instituição foi fundada em 1968 por um grupo de agricultores liderados por um padre italiano. Segundo Peres et al. (1998), esse programa é muito influenciado pela Igreja Católica e altamente comprometido com o sindicato dos trabalhadores rurais. As escolas que compõem o MEPES fazem parte do sistema regular de ensino do Estado e, por isso, seguem a grade curricular de disciplinas imposta pela Secretaria de Educação do Estado. Já a ARCAFAR recebe ajuda financeira do governo estadual, mas não segue as disciplinas obrigatórias do sistema de ensino. Entre os países da América Latina que utilizam a pedagogia de alternância, Peres et al. (1998) cita a Argentina, com um programa de ensino secundário apoiado pelo governo, e o Paraguai, com uma escola que utiliza a pedagogia de alternância na educação de jovens camponeses.

Algumas CFR inspiradas no modelo francês estão perdendo a identidade de como foram originalmente concebidas. A Escola Família Agrícola (EFA) ${ }^{13}$ de Muriaé (MG) é um exemplo disso. De acordo com Alves (1994), a EFA de Muriaé foi estabelecida seguindo a metodologia específica das Escolas Famílias Agrícolas do Espírito Santo. Entretanto, a autora desenvolveu um estudo para verificar a coerência entre a prática pedagógica utilizada por essa escola em relação à proposta original do MEPES. A metodologia usada para isso foi a análise documental realizada no MEPES, na Prefeitura Municipal de Muriaé, na Delegacia Regional de Ensino e na EFA de Muriaé. Os resultados encontrados demonstram que a EFA de Muriaé encontra-se quase totalmente descaracterizada, não guardando muitas semelhanças com as EFAs do Espírito Santo. Esta situação foi apontada como conseqüência dos conflitos de interesses entre a comunidade e seus mantenedores.

Os conflitos geradores dessa desunião foram provocados pelo desejo dos pais de que seus filhos dessem continuidade aos estudos ou arrumassem emprego nas cidades.

\footnotetext{
${ }^{13}$ Escola Família Agricola é o nome que a Casa Familiar Rural recebeu na Itália.
} 
Através de questionário feito junto aos pais, Alves (1994) apurou que essa era a preferência de $77,4 \%$ deles. Por isso, a principal luta da comunidade ocorreu no sentido de viabilizar a regulamentação do curso para que os jovens conseguissem prosseguir os estudos. A vitória da comunidade significou o primeiro passo no processo de descaracterização da escola como alternativa rural. Para que o curso fosse regulamentado, a Delegacia de Ensino impôs uma série de modificações no currículo, transformando a EFA praticamente numa escola tradicional. O estudo de Alves (1994) avalia essencialmente a pedagogia empregada por estas escolas e as dificuldades de sua implantação.

Todos os programas inspirados nas Casas Familiares Rurais francesas possuem em comum a aplicação da pedagogia de alternância a fim de beneficiar os jovens rurais. Entretanto, algumas dessas escolas têm-se adaptado às necessidades e vontades da comunidade, perdendo algumas de suas características básicas. Como demonstra 0 estudo de Alves (1994), a comunidade que não entende o sentido destes programas educacionais interfere com exigências que os transformam em escolas quase tradicionais. $\mathrm{O}$ que diferencia a maioria dos programas que utilizam a alternância é o grau de comprometimento que eles possuem com o sistema público de ensino.

No meio rural ainda existem as escolas rurais mantidas e geridas pelo Estado. Entretanto, o tipo de educação oferecida por elas não atende às especificidades da pequena produção. Grillo (1978) fez uma análise da situação das escolas rurais localizadas em um "bairro rural" do município de Passos (MG), onde a pequena propriedade $\mathrm{e}$ as relações de trabalho tipicamente familiares são predominantes. Observou-se que $84,8 \%$ das familias julgam que a criança deve estudar e trabalhar ao mesmo tempo. A expectativa profissional dos pais em relação aos filhos demonstrou que $33 \%$ dos entrevistados querem que o filho seja "doutor" (médico, engenheiro, advogado) e apenas $19 \%$ dos pais esperam que seus filhos sigam profissões relacionadas à terra (fazendeiro, lavrador). 
Analisando o conteúdo do ensino praticado nas escolas rurais, Grillo (1978) enfatiza que as práticas educativas fogem ao mundo rural com suas referências ao mundo urbano. "A escola não se incompatibiliza formalmente com a produção e estrutura agrárias. Mas é verdade que, ... está habilitando o indivíduo para um universo econômico e social que contraria, implicitamente, o rural" (Grillo, p.110). A pesquisa de campo levou-o a verificar que as práticas escolares compatíveis com a produção não eram ensinadas dentro da escola, mas sim através da família ou pelo extensionismo. Este estudo comprova a existência de deficiências no sistema de ensino tradicional, que não diferencia pedagogicamente os indivíduos quanto à sua origem e interesses.

As escolas agrotécnicas de $2^{\circ}$ grau mantidas pelo sistema público também deveriam formar mão-de-obra voltada para o meio rural. Entretanto, as aspirações profissionais dos jovens que se formam em escolas agrícolas estão relacionadas a empregos urbanos. Este fato reflete o prestígio que as profissões urbanas e a escolaridade superior exercem na sociedade. Alves Filho (1977) estudou os motivos de procura pelo curso agrotécnico e as aspirações ocupacionais e educacionais dos alunos que freqüentam essas escolas e encontrou resultados muito parecidos com os de Grillo (1978). Através de entrevistas, o estudo concluiu que as aspirações dos jovens concentram-se fortemente na procura de ocupações liberais que proporcionem prestígio ou possibilidade de melhores rendimentos. Apenas $10,9 \%$ dos alunos entrevistados consideram que as escolas agrícolas de $2^{\circ}$ grau são capazes de capacitar os agricultores para se dedicarem à agricultura. Outra conclusão importante desse estudo comprova que $82 \%$ dos alunos de origem rural aspiram a ocupações liberais, de gerência e alta supervisão. Esse trabalho constata que nem mesmo as escolas agrícolas conseguem formar indivíduos dispostos a trabalhar e se desenvolver no campo.

Um estudo mais recente realizado por Mello, Peres e Toyama ${ }^{14}$ sobre o impacto do curso técnico agrícola na formação do jovem em duas cidades do interior paulista

\footnotetext{
${ }^{\mathrm{I} 4}$ Mello, N.; Peres, F.C. \& Toyama, I. (Escola Superior de Agricultura Luiz de Queiroz - USP, Piracicaba, SP). Impactos de escuelas tecnicas agricolas publicas de São Paulo (1982-92). (Trabalho não publicado).
} 
confirma muitas das conclusões levantada pelo trabalho de Alves Filho na década de 70. Os dados encontrados por Mello, Peres e Toyama demonstram que apenas $30 \%$ dos jovens que estudam nas escolas agrícolas são de origem rural. Eles são, na maioria, filhos de pequenos empresários rurais. Outra característica importante levantada por estes autores é que $40 \%$ dos jovens intencionam realizar um curso de nível superior depois de concluírem o curso técnico. Destes, $30 \%$ são filhos de pequenos produtores rurais.

Tanto Grillo (1978) quanto Alves Filho (1977) e Mello, Peres \& Toyama apontam um problema muito sério: o governo investe na educação de jovens sem vocação para o trabalho rural. A origem deste problema está associada à visão dos próprios pais que, cansados de trabalhar sem realizar o sonho de uma vida melhor, preferem ver seus filhos exercendo profissões urbanas melhor remuneradas (Grillo, 1978).

$\mathrm{Na}$ atualidade, com o mundo globalizado, os produtores têm que estar sempre buscando o aperfeiçoamento. Existem alguns estudos que comprovam que a orientação empresarial é extremamente importante para a determinação da rentabilidade da agricultura familiar. Bastos \& Dijierkman (1997) analisaram a diferenciação social e os efeitos de uma reforma agrária, com dados do Chile. O objetivo do trabalho era analisar o impacto da experiência pré-reforma ("Treinamento informal em produção, comercialização e outras ações administrativas adquiridas pela prática do exercício e da extensão rural", Bastos \& Dijierkman,1997, p. 444) sobre o resultado econômico. A conclusão dos autores demonstra que a experiência influencia fortemente o desempenho do produtor. Em relação aos assentamentos rurais, os autores recomendam treinamento aos trabalhadores que estão se iniciando no comando da produção.

Dentro dessa mesma concepção sobre a importância da orientação empresarial nas pequenas propriedades, Araújo \& Bressan (1992) estudaram as características socioeconômicas dos parceleiros de um projeto de irrigação em Petrolina (PE). Nesse 
estudo foi analisada a relação entre rentabilidade econômica e variáveis como escolaridade, conhecimento tecnológico, orientação empresarial, experiência com culturas irrigadas, assistência técnica, área com salinização e outras. Muitas variáveis não foram significantes, como escolaridade, conhecimento tecnológico e assistência técnica. Entretanto, o que chamou mais a atenção foi a significância da variável orientação empresarial, a mais importante, comprovando a relevância da empresariedade no desenvolvimento de regiões muito pobres.

O estudo de Araújo \& Bressan (1992) e o de Bastos \& Dijierkman (1997) consideram que a experiência administrativa é fundamental para a sustentabilidade da agricultura familiar. Entretanto, noções administrativas adquiridas pela experiência podem não ser suficientes para a sustentabilidade social, econômica e ambiental da propriedade. É preciso, além dos conhecimentos administrativos e técnicos tradicionais passados de pai para filho, uma reestruturação nos modos de produção das pequenas propriedades com a introdução de novas técnicas empresariais e produtivas. De acordo com Chandler (1992), a capacitação gerencial traz aos indivíduos a capacidade de criar situações que possam aumentar a escala dos processos de produção, de perceber as necessidades dos consumidores e supri-las da maneira mais satisfatória possível, de saber sobre a quantidade de matéria-prima e confiabilidade dos fornecedores e como recrutar e treinar trabalhadores. Os trabalhadores com maior nível educacional podem ser considerados mais produtivos, com maior capacidade de adequação aos desequilíbrios econômicos e de aprender coisas novas.

Como visto anteriormente, o gerenciamento da propriedade rural é um instrumento essencial para se buscar o desenvolvimento sustentável da propriedade. $\mathrm{O}$ nível de concorrência gerado pela nova ordem econômica mundial indica a necessidade de transição de um "produtor familiar" para um "produtor profissional", ou seja, um empresário rural capaz de realizar a função de coordenação de todas as atividades, assumindo a responsabilidade pelos riscos das decisões tomadas (Adant,1987). 
Nunes (1995) mostrou em seu estudo que a produtividade do trabalho agrícola pode ser aumentada mediante a aplicação de técnicas de Administração de Recursos Humanos. No entanto, essas técnicas são pouco comuns no setor agrícola, sendo mais utilizadas nos setores mais dinâmicos da economia (indústria e serviços). Este autor aplicou estratégias de desenvolvimento de recursos humanos em uma empresa rural, com o objetivo de aumentar a produtividade de sua mão-de-obra. Para medir a compreensão dos trabalhadores rurais, utilizou um método denominado "Staf Management Audit". Essa técnica mede as atitudes, percepções e opiniões dos trabalhadores rurais com relação a oito características organizacionais da Administração de Recursos Humanos: liderança, realização pessoal, comunicação, relacionamento, tomada de decisão, metas, controle e performance.

Os resultados do trabalho de Nunes (1995) apontaram falhas na administração de técnicas de recursos humanos utilizadas pela empresa rural analisada. Apesar disso, metas de trabalho, fatores de performance e treinamento foram positivamente relacionados à produtividade do pessoal. $\mathrm{O}$ autor sugere que são necessárias algumas mudanças nestas práticas para alcançar o objetivo de aumentar a produtividade da mãode-obra do setor rural. Pode-se concluir que a aplicação de estratégias de desenvolvimento de recursos humanos no meio rural é prejudicada pela baixa qualificação dos trabalhadores. O setor rural só conheceu a importância do investimento em recursos humanos após o início da acirrada competição causada pela globalização. Até então, destreza manual e força física eram suficientes.

Este capítulo tratou essencialmente de três assuntos. A primeira parte permitiu a visualização dos impactos positivos da educação sobre o crescimento econômico nacional e sobre o setor rural mais especificamente. Leal \& Werlang (1991) analisaram o impacto da educação com uma amostra formada por trabalhadores residentes em áreas metropolitanas encontrando uma alta taxa de retorno pessoal. Locked et al. (1980), analisando os efeitos da educação sobre a produtividade em pequenas propriedades 
rurais, concluíram que a educação trouxe benefícios para a maioria dos países em desenvolvimento. Por outro lado, Gisser (1965) e Campos (1998) mostraram em seus trabalhos que a elevação da escolaridade no meio rural estimula a migração rural-urbana mais do que aumenta a produtividade agrícola. Neste sentido, o trabalho de Kassouf (1996) mostrou que os efeitos da educação e treinamento atualmente oferecidos no País, diferem entre os setores urbano e rural em favor do primeiro. De maneira similar, Ilha \& Lima (1989), utilizando o modelo de Welch (1970), confirmaram que a educação formal contribui para o aumento da produção em áreas modernas ou não, mas é mais efetiva no setor mais modernizado. Assim, Grossi (1978) acredita mais genericamente que, antes de introduzir fatores modernos no meio rural, deve-se investir em transformações de caráter educativo.

$\mathrm{Na}$ segunda parte do capítulo foram citados alguns trabalhos encontrados na literatura que retratam algumas experiências não-tradicionais de educação no meio rural. Grilo (1978) analisou as escolas rurais enfatizando sua desvinculação em relação ao mundo rural. Já Alves Filho (1977) estudou as aspirações ocupacionais e educacionais dos jovens que freqüentam escolas agrotécnicas. Dentro dessa linha, o trabalho de Mello, Peres \& Toyama ${ }^{15}$ confirmou as conclusões de Alves Filho para os dias atuais. Mais especificamente, Menezes Neto (1997) descreve a educação oferecida nos assentamentos dirigidos pelo MST formada basicamente por teoria, prática e ideais do Movimento. Foi visto que o programa do MST fornece mais aspectos ideológicos do que instrumentos que viabilizem a fixação dos jovens em suas propriedades. Finalmente, Cogo (1994), Alves (1994) e Peres et al. (1998) analisaram programas de educação rural que utilizam a pedagogia de alternância, mostrando que este tipo de proposta serve eficientemente para a educação de jovens rurais que estão comprometidos com as idéias dos programas e pretendem permanecer no campo. Quando isso não ocorre, o programa perde suas características e sua finalidade.

\footnotetext{
${ }^{15}$ Conforme autores citados na página 41.
} 
Por último, foram levantados alguns trabalhos que destacam a importância dos conhecimentos administrativos no meio rural. Araújo e Bressan (1992) estudaram a relação entre rentabilidade econômica e outras variáveis em pequenas propriedades rurais de Petrolina (PE), concluindo que a variável orientação empresarial foi a mais importante para aquela região. Neste sentido, Bastos \& Dijierkman (1997) analisaram a influência dos conhecimentos adquiridos pela experiência em ações administrativas sobre o desempenho do produtor, concluindo que produtores inexperientes são menos produtivos. Já Nunes (1995) mostrou que a produtividade do setor rural pode ser aumentada com a disseminação de técnicas de Administração em Recursos Humanos pouco utilizadas pelas empresas do setor agrícola.

Pode-se dizer que, em geral, os trabalhos encontrados na literatura confirmam a importância de programas educacionais voltados especificamente para a população rural. O meio nural exige uma educação diferenciada, que mescle as disciplinas básicas (português, matemática etc.), técnicas e administrativas necessárias para formar um profissional capaz de compreender e se adaptar às inovações surgidas a cada momento sem afastar os jovens da sua realidade. As experiências educacionais analisadas neste capitulo confirmam essa necessidade, principalmente no meio rural carente.

Em face das propostas do PROJOVEM e da revisão de literatura, revelando a realidade da educação oferecida aos jovens rurais e as dificuldades dos programas existentes, foi possível formular algumas questões que tornarão evidente ou não a importância deste tipo de programa para o meio rural. Algumas das perguntas $(5,6,7)$, apesar de já terem sido exaustivamente estudadas e tidas como verdadeiras até mesmo pelo senso comum, foram verificadas para a população que compõe o PROJOVEM, um programa de metodologia diferenciada e que atende, na grande maioria, filhos de pequenos produtores rurais.

1. Os jovens percebem diferença entre o tipo de ensino promovido pelo PROJOVEM e pelas escolas tradicionais? 
2. O PROJOVEM estimula a troca de informações entre pais e filhos, impedindo uma interrupção cultural e tecnológica entre as gerações?

3. Quais as diferenças entre o PROJOVEM e outros programas que utilizam a pedagogia de alternância?

4. Os pais dos jovens que freqüentam o programa aceitam o uso do termo "empresário" para caracterizar seu trabalho?

5. O nível de escolaridade dos pais interfere positivamente no nível de escolaridade dos filhos?

6. Famílias que vivem há mais tempo no meio rural possuem melhor situação econômica que as famílias que estão há menos tempo (especialmente assentados)?

7. Pais que possuem maior escolaridade formal são os que detêm maiores níveis de rendimento?

8. O tipo de educação oferecida pelo PROJOVEM tende a fixar o jovem no campo?

9. A demanda pelo programa é maior entre os filhos de proprietários de terra que entre filhos de parceiros, arrendatários e trabalhadores rurais?

10. Os pais que possuem filhos no programa participam da educação de seus filhos?

11. Os monitores recebem capacitação suficiente para o exercício de orientador do aprendizado do jovem?

Como se pôde verificar neste capítulo, muitos estudos tratam do retorno da educação, do tipo de educação oferecida aos jovens rurais e da importância de conhecimentos administrativos no meio agrícola. No entanto, nenhum destes estudos realiza uma análise conjunta dos benefícios econômicos, sociais (incluindo mudanças 
técnicas e administrativas) e pedagógicos advindos de uma educação diferenciada oferecida aos filhos de pequenos produtores rurais. 


\section{METODOLOGIA}

\subsection{Procedimentos gerais}

Para alcançar o objetivo deste estudo foram utilizadas fontes primárias e secundárias de obtenção de dados. As fontes secundárias forneceram dados exclusivamente para o cálculo da taxa de retorno à educação e foram obtidas junto ao Centro Estadual de Educação Tecnológica Paula Souza (CEETEPS), estatísticas do IBGE e fontes da literatura (Hoffmann, 1989 e 1997).

A fonte primária de informações utilizada neste estudo foi obtida por meio de entrevistas. A entrevista forneceu os dados necessários à análise socioeconômica das expectativas dos jovens e suas famílias e ao cálculo da taxa de retorno. Além disso, as entrevistas permitiram levantar as características e a função pedagógica do monitores envolvidos no programa. Os dados primários foram coletados entre maio e julho de 1999.

\subsection{Definição da amostra}

Para a escolha da amostra foram considerados os nove núcleos do PROJOVEM. Considerando a restrição temporal e levando em conta os recursos disponíveis, verificamos ser possível trabalhar apenas com quatro unidades sem perder em qualidade e em generalidade das informações. Tomando por critério a regra de Tompkin (1967), uma amostra deve ser formada no mínimo por 50 observações. "Se a população é menor que 5.000 , cinqüenta mais $2 \%$ é bom. Se mais de $5.000,1 \%$ mais cinqüenta pode ser usado" (Tompkin, 1967, p.55). Para diminuir a possibilidade de viés, os núcleos foram 
divididos em quatro grupos de acordo com o seu enquadramento dentro da linha básica que rege o programa. A classificação dos núcleos foi feita pela equipe de assessores da Associação Central de Pais que acompanha o programa desde sua implantação. O grupo escolhido como o mais próximo da linha básica foi composto apenas pelo núcleo de Promissão; em seguida os núcleos de Maracaí e Presidente Venceslau; depois, Rancharia, Garça e Votuporanga e, finalmente, Peruibe, Vera Cruz e Bananal. Dentre estes quatro grupos foram sorteados um núcleo de cada um, exceto no caso de Promissão, que não precisou de sorteio. Os núcleos utilizados neste estudo foram: Promissão, Maracaí, Rancharia e Peruíbe.

No momento da seleção da amostra, a Assessoria da ACP informou que o PROJOVEM contava com 9 núcleos e 122 jovens. Este foi o número utilizado no cálculo da amostragem. Entretanto, durante as visitas aos núcleos e contato com os monitores constatou-se que o PROJOVEM possuía no momento da pesquisa mais de 180 jovens, pois novas turmas estavam sendo iniciadas em alguns núcleos. Os quatro núcleos sorteados possuíam, segundo informações dos monitores, 96 jovens na data da entrevista e não aproximadamente 70 como havia informado a Assessoria. Visando entrevistar, aproximadamente, $50 \%$ do número total de jovens inicialmente informado pela Assessoria e garantir o cumprimento da regra de Tompikin, foi adotado como limite mínimo para o número de entrevistas em cada núcleo:

$n=\frac{X}{96} \cdot 60$, onde $X$ é o número de jovens freqüentando cada um dos núcleos pesquisados até a última semana de atividades. Este mesmo número foi adotado para a amostra formada pelos pais. 


\subsection{Os núcleos sorteados}

\section{- Núcleo de Promissão}

O trabalho de coleta de dados iniciou-se pelo núcleo situado na cidade de Promissão, noroeste do Estado de São Paulo. Este núcleo, na data da entrevista, atendia 40 jovens pertencentes a uma área de assentamento rural, divididos em três turmas. Por se tratar de um assentamento relativamente antigo (os primeiros lotes foram distribuídos em 1989), as famílias vivem em condições muito parecidas com as propriedades de regiões de agricultura tradicionalmente familiar, isto é, apresentam melhor qualidade de vida se comparadas a outras áreas de assentamentos recentes. A maioria das famílias possui casas de alvenaria, veículos e razoável experiência com trabalhos rurais. Para suprir a falta de alguns recursos, principalmente maquinários agricolas, essa comunidade se organizou e formou uma cooperativa que fornece os equipamentos necessários para o preparo do solo, plantio, manutenção da lavoura e colheita para grande parte dos assentados.

O núcleo de Promissão conseguiu com o INCRA (Instituto Nacional de Colonização e Reforma Agrária) a doação de um terreno dentro da agrovila e os recursos para a construção da sede do programa, com salas de aula, hiblioteca, refeitório e alojamento para os jovens. Essas instalações estão sendo utilizadas desde o início de 1999.

\section{- Núcleo de Peruíbe}

O núcleo de Peruíbe localiza-se no litoral sul do Estado de São Paulo, numa região extremamente montanhosa e acidentada, o que dificulta a prática de muitas culturas e a locomoção dos jovens e monitores, principalmente nos dias de chuva. A principal atividade agrícola da região é a plantação de bananas. $O$ núcleo está localizado no CEPE (Centro de Educação Profisssional e Ecológica), local doado e mantido por uma 
organização não-governamental européia para ser ocupado por escolas que promovessem cursos para os jovens carentes da região. $O$ local possui excelente estrutura física: salas de aula, alojamento, refeitório e biblioteca. Por utilizar estas estruturas, o núcleo do PROJOVEM de Peruíbe tornou-se dependente da instituição que o mantém, criando uma forma de comodismo nos pais e fugindo da linha básica que determina as condições para um núcleo ser PROJOVEM. Os pais não se preocupam em conseguir instalações próprias para o núcleo, nem contribuem para a alimentação dos filhos, refletindo a atitude "paternalista" que caracteriza a relação do CEPE com a comunidade.

Alguns dos jovens atendidos pelo PROJOVEM de Peruíbe possuem características urbanas muito fortes: usam cabelos coloridos, tatuagens, brincos e gírias que os diferenciam dos demais. Isto, provavelmente, é provocado por influência da principal atividade econômica da cidade, o turismo.

\section{- Núcleo de Rancharia}

O núcleo do PROJOVEM de Rancharia atende, principalmente, filhos de integrantes do Movimento Sem Terra que viveram acampados por, aproximadamente, cinco anos numa fazenda localizada entre os municípios de Rancharia e Martinópolis, situados no oeste do Estado de São Paulo. Essas famílias receberam recentemente seus lotes definitivos. A maioria, no entanto, não conseguiu ficar nos locais onde já havia realizado algumas melhorias, tendo que começar tudo de novo. Alguns receberam lotes em locais de difícil acesso onde só existe mato fechado. As condições de vida dessas famílias são muito precárias. Em um dos assentamentos não existe energia elétrica e a água é conseguida com muita dificuldade (poços e cisternas). Alguns poucos construíram casas, mas muitos ainda vivem em barracos de lona ou madeirite.

O núcleo de Rancharia funciona dentro das dependências da Escola Agrotécnica de Rancharia e os participantes do PROJOVEM dividem espaço com os jovens que 
estudam na escola agrícola. Apesar das facilidades oferecidas pela localização da escola, os pais estão providenciando um local para a construção da nova sede.

\section{- Núcleo de Maracaí}

O núcleo da Colônia Rio-Grandense, localizado no município de Maracai, atende, principalmente, famílias descendentes de imigrantes alemães, o que lhes confere características econômicas, sociais e culturais muito particulares. A Colônia está localizada numa região extremamente fértil no Vale do Rio Paranapanema, divisa dos Estados de São Paulo e Paraná.

O PROJOVEM da Colônia possui aproximadamente 30 jovens divididos em 2 turmas. Grande parte das famílias envolvidas no programa mora na cidade apesar de possuir e trabalhar em propriedades rurais. Além disso, nesse núcleo existem alguns jovens que não possuem terra e que realizarão seus projetos em outras propriedades. As propriedades e casas visitadas são muito diferentes das encontradas no restante dos núcleos que fazem parte do PROJOVEM. As casas são bem cuidadas, grandes e confortáveis. As propriedades rurais são maiores e detentoras de tecnologia. É comum encontrar proprietários que possuam dois tratores ou duas colhedeiras.

$\mathrm{Na}$ década passada e início dessa, a região de Maracaí foi muito rica e próspera. Os produtores da região formaram uma cooperativa (Cooperativa Rio-Grandense) que proporcionou um período de grande desenvolvimento, mas essa cooperativa faliu e deixou muitos produtores endividados. Existe uma influência muito forte da Igreja Luterana. A Igreja serviu como disseminadora da idéia do PROJOVEM e mobilizadora da primeira turma. Durante os primeiros dois anos de funcionamento do núcleo um expastor da Igreja Luterana e principal líder comunitário local foi o presidente da Associação local de pais, apesar de não possuir filhos no programa. 


\subsection{Critérios definidores para a coleta de dados primários}

\subsubsection{Forma de obtenção dos dados}

Os dados foram obtidos por meio de entrevistas padronizadas. Esse método de coleta de dados segue um roteiro de perguntas feitas a todos os entrevistados da mesma forma e na mesma ordem. Este tipo de entrevista é muito parecido com a aplicação de um questionário, só que permite uma certa flexibilidade, pois conta com a presença do entrevistador para alguns eventuais esclarecimentos. De acordo com Menga \& André (1986), a entrevista padronizada "visa à obtenção de resultados uniformes entre os entrevistados, permitindo assim uma comparação imediata, em geral mediante tratamentos estatísticos" (p. 34). Além disso, no caso deste trabalho, a entrevista tem uma vantagem muito importante, pois ela pode ser utilizada em todos os segmentos da população, independentemente do nível de escolaridade do entrevistado (Marconi \& Lakatos,1990).

Para chegar aos aspectos socioeconômicos foram levantadas informações sobre a origem e condições de vida dos jovens e famílias, técnicas de produção, disponibilidade e necessidade de recursos. A entrevista permitiu ainda analisar os conhecimentos administrativos dos produtores sobre estratégias de produção e comercialização. E, por fim, as aspirações dos jovens foram levantadas com base em seus desejos profissionais e impressões sobre o futuro.

A análise pedagógica, apesar do nome, limitou-se à descrição do papel do monitor dentro do programa, suas dificuldades, angústias e expectativas. Aproveitou-se para analisar a aplicação do construtivismo pelos monitores e a motivação dos jovens frente a esta postura. Foram elaborados três roteiros distintos com base nas variáveis a serem analisadas: 
a) Roteiro 1- respondido pelos chefes de família ou responsáveis que possuem filhos freqüentando o PROJOVEM, aleatoriamente selecionados.

b) Roteiro 2- respondido por jovens que freqüentam o programa, aleatoriamente selecionados.

c) Roteiro 3- respondido por todos os monitores dos núcleos selecionados.

A entrevista foi feita com base em questões de caráter qualitativo e quantitativo. As respostas obtidas permitiram, além de perceber que tipos de benefícios o programa trouxe ou está trazendo para os jovens e seus familiares, conseguir os dados sobre os custos dos jovens em freqüentar o PROJOVEM. Além disso, as entrevistas permitiram identificar falhas no funcionamento do programa e algumas das externalidades produzidas por este tipo de educação no meio rural.

\subsubsection{Pessoas entrevistadas}

Foram entrevistados 64 jovens, 64 pais e todos os monitores que faziam parte dos quatro núcleos sorteados (nove monitores).

Tabela 5.1- Distribuição numérica e percentual dos jovens freqüentadores e entrevistados dos núcleos sorteados - 1999.

\begin{tabular}{lcccc}
\hline & $\begin{array}{c}\text { Jovens por núcleo } \\
\text { selecionado }\end{array}$ & \multicolumn{2}{c}{$\begin{array}{c}\text { Jovens } \\
\text { entrevistados } \\
\text { por núcleo }\end{array}$} \\
\hline Núcleos & $\mathrm{n}^{\mathbf{0}}$ & $\%$ & $\mathrm{n}^{\circ}$ & $\%$ \\
\hline Promissão & 40 & 41,7 & 26 & 40,6 \\
Peruíbe & 13 & 13,5 & 9 & 14,1 \\
Rancharia & 13 & 13,5 & 9 & 14,1 \\
Maracaí & 30 & 31,3 & 20 & 31,3 \\
\hline Total & 96 & 100 & 64 & 100 \\
\hline
\end{tabular}

Fonte: dados da pesquisa, 1999. 


\subsection{Tratamento das informações}

Para facilitar a interpretação da análise estatística, os dados primários obtidos pelas entrevistas foram codificados e as respostas foram agrupadas em categorias numéricas. Por exemplo, a variável "escolap", que analisa a escolaridade dos pais envolvidos no programa, foi conseguida após a agregação das respostas em 7 categorias associadas a números: 0 , analfabetos; 1 , primário incompleto; 2 , primário completo; 3 , ginásio $\left(5^{\mathrm{a}}\right.$ a $8^{\mathrm{a}}$ série) incompleto; 4 , ginásio completo; 5 , segundo grau incompleto; e, 6, segundo grau completo. Este tipo de classificação facilita a aplicação de estatísticas, embora contenha características cardinais arbitrariamente impostas pela escala escolhida.

Para responder às questões levantadas no final do capítulo 4 sobre o PROJOVEM e seus envolvidos foram utilizadas a distribuição de freqüências e o teste de correlação de Spearman. A escolha destas estatísticas ocorreu devido ao tipo de variáveis (qualitativas ou quantitativas) envolvidas no questionamento. Dependendo da questão, é possível verificá-la apenas com o uso de frequiências. A distribuição de freqüências facilita o entendimento do comportamento das variáveis, pois as tabelas de freqüências permitem descobrir o número (ou porcentagem) de ocorrências de cada uma das categorias da variável.

Algumas questões permitiram além do uso de freqüências, a utilização do teste de correlação de Spearman. Segundo Levin (1984), este teste determina o grau de associação entre variáveis ordinais, ou seja, variáveis às quais é possivel atribuir postos ou "graduação" a partir da presença de uma característica particular.

Em símbolos:

$r_{s}=1-\frac{6 \sum D^{2}}{N\left(N^{2}-1\right)}, \quad$ onde:

$r_{s}=$ coeficiente de correlação 
$\mathrm{D}=$ diferença entre postos ou "graduação"

$\mathrm{N}=$ tamanho da amostra

O procedimento para testar a significância do coeficiente de correlação de Spearman, isto é, saber se a "informação" pode ser generalizada para toda a população ou não, é realizado por meio de comparações entre os valores do $r_{s}$ calculado e do $r_{s}$ crítico. $O r_{s}$ crítico é fornecido pela tabela de valores de $r_{\mathrm{s}}$ aos níveis de significância de 0,05 e 0,01 (Levin, 1984, p.362). O valor do $r_{s}$ crítico depende apenas do tamanho da amostra $(N)$ e não, como em outros testes, dos graus de liberdade. Para que um $r_{s}$ calculado seja significante é necessário que ele cumpra a seguinte condição: $r_{\mathrm{s}}$ calculado $\geq \mathrm{r}_{\mathrm{s}}$ crítico. Se o $r_{s}$ calculado for maior que o crítico rejeita-se a hipótese nula de que $r_{s}=0$, ou seja, não existe correlação entre as variáveis. Finalmente, o coeficiente de correlação de Spearman $\left(r_{\mathrm{s}}\right)$ só deve ser utilizado quando satisfeitas as seguintes condições:

a) as relações entre as variáveis $\mathrm{X}$ e $\mathrm{Y}$ são lineares;

b) as variáveis $\mathrm{X}$ e $\mathrm{Y}$ devem permitir ordenação ou atribuição de postos;

c) a amostra deve ser obtida aleatoriamente de uma dada população.

\subsection{O cálculo da taxa interna de retorno}

Foi calculada a taxa interna de retorno advinda do investimento feito em educação pelos jovens que estudam no PROJOVEM. Para isso, foi feita uma comparação entre os custos e rendimentos dos jovens rurais que freqüentam o PROJOVEM e aqueles que não freqüentam. Para tanto, considerou-se que os dois tipos de jovens que foram comparados têm 16 anos de idade (idade em que a maioria dos jovens entrevistados entraram para o programa), uma vida útil dos 16 aos 60 anos e possuem o mesmo nível de escolaridade formal, ou seja, a única diferença entre eles resulta dos efeitos do investimento (tempo, dinheiro) realizado no PROJOVEM durante os três anos de curso, pois como eles 
tiveram a mesma escolaridade formal é provável que, se não realizassem nenhum tipo de aprendizagem adicional, ambos tivessem os mesmos custos em educação e os mesmos rendimentos depois de formados.

A taxa interna de retorno (TIR) de um investimento é a taxa de desconto que iguala os valores presentes dos custos e dos rendimentos, ou, de outra forma, a que anula o valor presente do fluxo de rendimentos líquidos. Como não se dispõe de dados sobre os ganhos futuros dos jovens rurais, foram assumidas algumas proxies de rendimentos ${ }^{16}$. Como dito anteriormente, quando um jovem que está no PROJOVEM não possui os recursos financeiros para a implantação de seu projeto, ele terá a possibilidade de conseguir um financiamento. Para este financiamento ser aprovado o projeto deve ter um retorno que permita ao jovem pagar, no mínimo, os juros do empréstimo e sua mãode-obra. Então, foi assumido como rendimento do jovem que cursa o programa o retorno de $8 \%$ sobre o valor máximo do financiamento permitido ao jovem para a elaboração de seu projeto $(\mathrm{R} \$ 3.000,00)^{17}$ mais um valor imputado à mão-de-obra do jovem no projeto. Já para os jovens rurais que não cursaram o PROJOVEM foram admitidas duas hipóteses. Ou eles continuam trabalhando sem muitas perspectivas no meio rural ou vão para as cidades se sujeitar a qualquer emprego de baixa qualificação. Segundo Campos (1998), um dos principais setores absorvedores de mão-de-obra advinda do campo é o setor de construção civil ${ }^{18}$. Portanto, foram adotados para os jovens rurais que não cursaram o PROJOVEM duas alternativas de rendimentos: a de um trabalhador rural que trabalhou no mínimo 15 horas semanais na agricultura paulista em 1995 (Hoffmann, 1997) e o rendimento mediano de um servente de obras que trabalha 45 horas semanais no Estado de São Paulo em 1998-99 (IBGE).

\footnotetext{
${ }^{16}$ O PROJOVEM ainda não possui nenhuma turma formada.

${ }^{17}$ Alguns projetos já na fase de avaliação apresentam TIR próximas deste valor.

${ }^{18}$ Campos (1998) baseou-se em pesquisa realizada com os trabalhadores da construção civil da região metropolitana de Curitiba divulgada pelo SINDUSCON em maio de 1995. Segundo essa pesquisa, dos trabalhadores que ingressaram neste setor $52,3 \%$ eram provenientes do campo.
} 
Como os custos dos dois jovens em cursar a escola formal anulam-se por terem ambos cursado o mesmo tempo de escola, resta somente os custos envolvidos na educação oferecida pelo PROJOVEM. Foram considerados para efeito do cálculo da TIR os custos diretos e indiretos mais relevantes nos 4 núcleos pesquisados. Os custos diretos totais da educação incluem todos os gastos financeiros por parte do estudante e do Estado. Os custos indiretos significam a renda sacrificada devido ao tempo dedicado pelos jovens à educação. A Figura 2 a seguir descreve os custos que foram considerados para o cálculo da taxa interna de retorno.

Figura 2: Despesas totais envolvidas na educação oferecida pelo PROJOVEM.

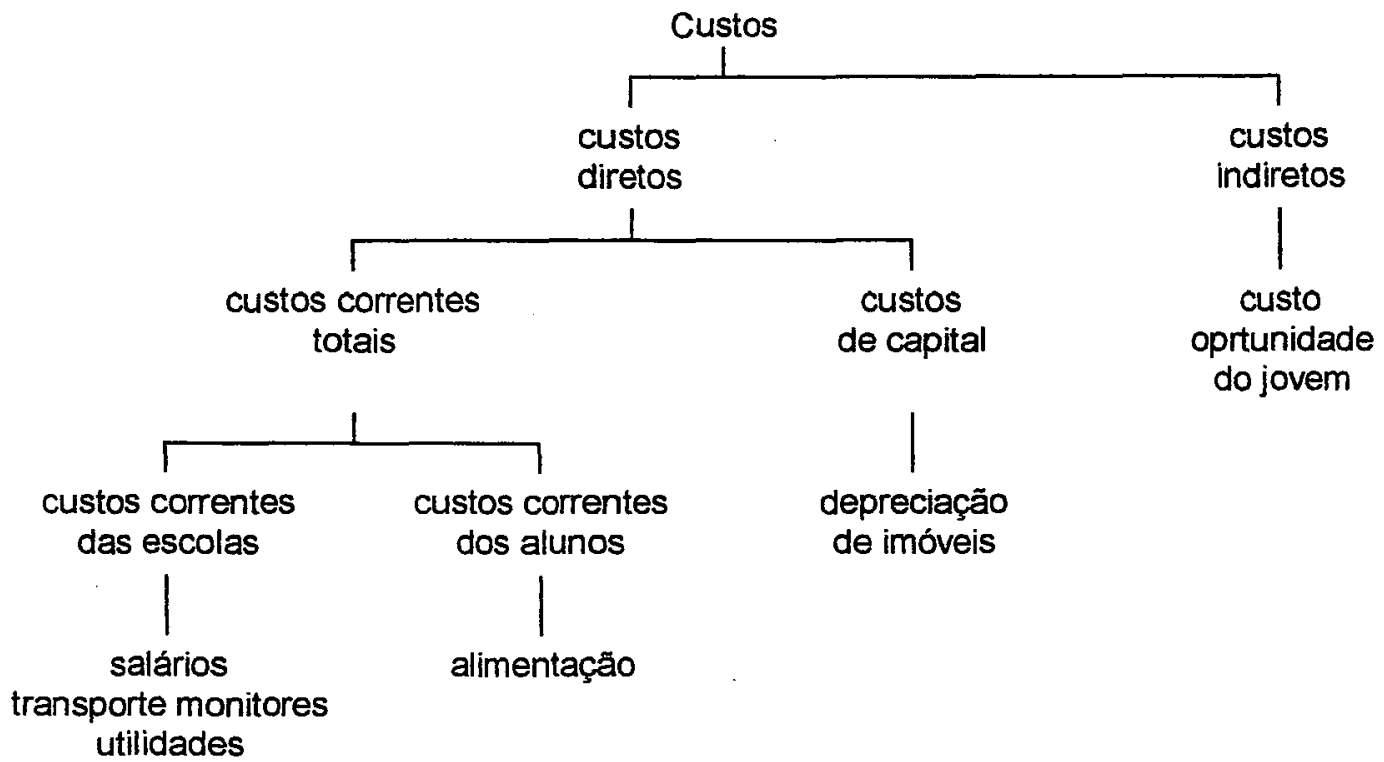

O CEETEPS forneceu os gastos totais em 1998 com salários dos monitores, cozinheiros, quilometragem e treinamento. $\mathrm{O}$ restante dos dados sobre custos foi obtido durante as entrevistas às famílias. 
De posse dos dados, o cálculo da TIR foi realizado em duas etapas: primeiramente, supondo os jovens do PROJOVEM com rendimento dos projetos elaborados por eles mesmos e os jovens que não cursaram o PROJOVEM com salários de serventes. Em seguida, considerou-se o jovem do PROJOVEM com rendimento dos projetos e o jovem que não cursou o PROJOVEM com rendimentos de trabalhador rural.

\subsubsection{Descrição das variáveis envolvidas no cálculo da Taxa Interna de Retorno (TIR)}

As variáveis foram definidas de forma a preencher os dados necessários para o cálculo da taxa interna de retorno aos investimentos em educação conforme recomenda a Teoria do Capital Humano.

\section{-Renda}

Como dito anteriormente, devido às dificuldades de trabalhar com dados reais sobre os rendimentos dos jovens depois de formados, este estudo assume algumas possibilidades de ganhos futuros para os jovens do meio rural. Foi considerada como proxy dos possíveis rendimentos a ser recebidos pelos jovens que cursaram o PROJOVEM:

Rendimento sobre o projeto $\left(\mathbf{R}_{\mathrm{pj}}\right)$ : para compor esta variável, foi suposta uma taxa anual mínima de retorno para os projetos elaborados pelos jovens no valor de $8 \%$ sobre o valor máximo de financiamento permitido $(\mathrm{R} \$ 3.000,00)$ mais um valor atribuído à mão-de-obra do jovem na implantação do projeto. $O$ valor encontrado para este "salário" foi de 2 salários mínimos e foi retirado dos primeiros projetos em fase de conclusão dos núcleos de Maracai e Promissão ${ }^{19}$. Este valor foi considerado razoável por permitir ao jovem empresário rural o pagamento de sua mão-de-obra, do

\footnotetext{
${ }^{19}$ Estes dois núcleos estão mais adiantados em relação aos outros, com os jovens concluindo a elaboração dos projetos.
} 
empréstimo (que cobra juros de $6 \%$ a.a.) e, ainda, obter uma margem de lucro sobre seu empreendimento.

O valor do salário mínimo em vigor é $\mathrm{R} \$ 136,00$ (dez./1999). Então, o rendimento anual advindo da realização e implantação do projeto é:

$$
R_{p j}=(3.000 \times 0,08)+(136 \times 2 \times 12)=R \$ 3.504,00
$$

Considerando que o jovem que não cursou o PROJOVEM tem duas alternativas de trabalho, no campo ou na cidade, foram examinadas duas possibilidades de rendimento:

Salário de servente (Ss): o salário de servente é considerado uma forma de rendimento alternativo ao trabalhador rural fora do meio agrícola. Para a composição do salário esperado para um servente no Estado de São Paulo, considerou-se a expectativa de emprego deste trabalhador. As informações sobre o salário de serventes foram fornecidas pela Pesquisa Anual de Informações sobre Construção Civil (PAIC/IBGE) e a taxa de desemprego na construção civil no Estado de São Paulo foi estimada pela Pesquisa Metropolitana de Emprego (PME- IBGE).

Para se chegar ao salário esperado por um servente que trabalha 8 horas por dia e 22 dias por mês, considerou-se a média mensal dos salários medianos ${ }^{20}$ de setembro de 1998 a outubro de 1999 e a taxa média de desemprego deste mesmo período. A expressão que determina o salário esperado é:

$S^{e}=S(1-t d)$, onde $\mathrm{S}$ é a média mensal dos salários mediano de um servente e $t d$ é a taxa média de desemprego na construção civil no Estado de São Paulo. Tem-se assim:

$S^{e}=269,28 .(1-0,10) \cdot 12=\mathrm{R} \$ 2 \cdot 908,82 / \mathrm{ano}$

\footnotetext{
${ }^{20}$ Foi usado o salário mediano porque o IBGE só possui essa medida de salário para os empregados da indústria de construção civil.
} 
Rendimento do trabalhador rural ( $\left.\mathbf{R}_{\mathbf{t r}}\right)$ : Hoffmann (1997), utilizando dados da PNAD1995, fez um estudo buscando descrever a distribuição de renda entre pessoas ocupadas na agricultura. Neste trabalho, o autor encontrou o rendimento mediano de todas as pessoas que trabalham no mínimo 15 horas semanais na agricultura em algumas regiões brasileiras e, em particular, no Estado de São Paulo. O rendimento mediano mensal de um trabalhador rural no Estado de São Paulo, encontrado por Hoffmann (1997) foi de $\mathrm{R} \$ 200,00$, ou $(200.12)=\mathrm{R} \$ 2.400,00 /$ ano.

\section{- Custos}

Para chegar ao custo/ano/jovem do Programa de Formação de Jovens Empresários Rurais foram consideradas as seguintes variáveis:

Salário dos monitores por jovem $\left(G_{\mathrm{sm}}\right)$ : gasto anual com os salários dos monitores dos núcleos pesquisados dividido pelo número de jovens que cursavam os 4 núcleos.

Salário dos cozinheiros por jovem $\left(\mathrm{G}_{\mathrm{sc}}\right)$ : gasto anual com os salários dos cozinheiros dos núcleos pesquisados dividido pelo número de jovens que cursavam os 4 núcleos.

Gastos com quilometragem por jovem $\left(\mathbf{G}_{\mathbf{k m}}\right)$ : gasto anual com quilometragem para visitas nos núcleos pesquisados dividido pelo número de jovens que cursavam os 4 núcleos.

Gastos com treinamento por jovem $\left(\mathbf{G}_{t}\right)$ : gasto anual com encontros de capacitação de pais e monitores dos núcleos rateado entre os 9 núcleos que compõem o programa. $\mathrm{O}$ valor obtido por núcleo foi multiplicado por 4 (núcleos pesquisados) e dividido pelo número total de jovens que cursavam os 4 núcleos.

Gastos com alimentação $\left(\mathbf{G}_{\mathbf{a}}\right)$ : média dos gastos mensais com alimentação indicados pelos pais durante as entrevistas multiplicada por 12 (meses). 
Custos de manutenção por jovem $\left(\mathbf{C}_{\mathrm{m}}\right)$ : os gastos com manutenção do núcleo de Promissão ${ }^{21}$ foram adotados como referência para os outros 3 núcleos. Os custos de manutenção mais relevantes foram: gastos com energia, gás, telefone e conserto de computadores, totalizando um gasto de $\mathrm{R} \$ 1.680,00 /$ ano. Este custo foi multiplicado por 4 (núcleos) e dividido pelo número de jovens que cursavam os 4 núcleos pesquisados. $O$ valor dos gastos com luz foi fornecido pela Prefeitura de Promissão, responsável pelo custeio deste item. O restante dos custos foi obtido junto à Associação de Pais de Promissão.

Depreciação dos imóveis por jovem (D): Tomou-se como referência para os núcleos pesquisados a depreciação obtida no núcleo de Promissão (área construída $\cong 200 \mathrm{~m}^{2} \mathrm{e}$ custo da obra $=\mathrm{R} \$ 140.000,00)$. A taxa de depreciação linear foi calculada dividindo o custo inicial do imóvel pelo período de vida útil do mesmo ${ }^{22}$. O valor da depreciação do prédio de Promissão foi multiplicado por 4 e dividido pelo número de jovens dos núcleos pesquisados.

Custo de oportunidade (Co): é o valor que o jovem está deixando de ganhar por freqüentar o PROJOVEM, ou seja, uma semana de trabalho/mês. Considerando que o jovem participante do programa trabalha como trabalhador rural, o seu custo de oportunidade durante o ano seria $1 / 4$ do rendimento anual deste trabalhador, isto é, $\mathrm{R} \$ 600,00(1 / 4$ de $\mathrm{R} \$ 2.400,00)$.

O custo total do PROJOVEM, por jovem, pode ser expressado por:

$$
C T_{j}=G_{s m}+G_{s c}+G_{k m}+G_{t}+G_{a l}+C_{m}+D+C o
$$

\footnotetext{
${ }^{21} \mathrm{O}$ núcleo de Promissão foi adotado como modelo para os outros núcleos por apresentar as condições mínimas de infra-estrutura desejáveis para um núcleo do PROJOVEM, como sede própria, com todas as condições necessárias para o convivio do jovem em núcleo (sala de aula, biblioteca, computadores, alojamentos, banheiros, refeitório, poço artesiano etc.)

${ }^{22}$ Hoffmann (1984) considera a vida útil de uma construção feita de tijolos, taipa e telhas 50 anos.
} 
Este capítulo mostrou os passos a ser percorridos para o cumprimento dos objetivos propostos. Foram apresentados a forma de coleta de dados, a natureza das entrevistas, os testes estatísticos utilizados e a maneira de calcular a taxa interna de retorno educacional a fim de saber se o PROJOVEM é capaz de formar cidadãos-empresários com competência para gerir seu próprio trabalho e, com isso, aumentar seus rendimentos. 
"O segredo da existência humana consiste não somente em viver, mas ainda em encontrar um motivo de viver"

Fiodor Dostoievski

\section{ANÁLISE E DISCUSSÃO DOS RESULTADOS}

Neste capítulo são apresentados e discutidos os resultados das entrevistas realizadas com os chefes de família, os jovens e os monitores do PROJOVEM, de forma a atingir os objetivos propostos no estudo. Para tanto, a análise enfoca três etapas. Primeiramente, realizou-se uma caracterização geral dos indivíduos envolvidos diretamente no PROJOVEM: jovens, pais e monitores. Numa segunda etapa, foi realizada a análise estatística das questões levantadas no capítulo 4 . Por último, foi verificada a taxa interna de retorno advinda do investimento no PROJOVEM.

\subsection{Características gerais dos indivíduos que compõem o Programa de Formação de Jovens Empresários Rurais}

A análise inicial enfocará três aspectos: a caracterização socioeconômica das famílias envolvidas no programa, assim como os tipos de produção e o nível técnico de suas propriedades; o comportamento administrativo e os conhecimentos adquiridos até o momento pelos jovens; e, por último, as perspectivas das famílias e dos jovens agricultores que participam do programa. Esta parte do estudo ainda inclui uma tímida análise dos aspectos pedagógicos e operacionais que permite detectar falhas e apontar melhorias no processo de ensino e funcionamento do programa. Para isso, foram realizadas entrevistas também com os monitores, buscando caracterizá-los, definir sua função e a forma como eles vêem o PROJOVEM.

Apesar de o programa depender do envolvimento conjunto de pais, jovens e monitores, a apresentação dos fatos observados foi dividida, mas mantendo uma relação entre eles 
para não haver perda de informações e conduzir a conclusões vagas ou errôneas. Nas palavras do especialista:

\begin{abstract}
..."A própria natureza do Programa, onde todas as partes são intimamente interdependentes, faz com que uma tentativa de descrição e análise de aspectos isolados se torne uma tarefa muito dificil e potencialmente distorcedora da realidade - a realidade não é compartimentada. Contudo, uma avaliação "holistica" somente nos levaria a descrições e conclusões tão genéricas e vagas, que praticamente não teriam grande significado nem utilidade para a tomada de quaisquer eventuais medidas corretivas"(Burke, 1998, p.3).
\end{abstract}

Nos itens seguintes, são apresentados os resultados obtidos por meio da pesquisa de campo e os comentários considerados relevantes para o intuito deste trabalho. Inicialmente serão analisados os dados que caracterizam a amostra formada pelos chefes de familia, em seguida os jovens e depois os monitores.

\title{
- Características e visão dos chefes de família
}

A idade média dos chefes de família que possuem filhos no PROJOVEM é de 50 anos, com idades variando de 36 a 68 anos, sendo que a maioria deles $(58,3 \%)$ tem menos de 50 anos, faixa etária bastante favorável ao desempenho produtivo na agricultura. A média de filhos, por familia, é de 4 , seguindo a idéia exposta por alguns dos entrevistados de que "quanto mais filhos, mais braços para o trabalho".

A escolaridade dos chefes de família é muito baixa, assim como a escolaridade de grande parte das pessoas que residem no setor rural. Somente $20 \%$ dos pais entrevistados conseguiram transpor a barreira da "quarta série" e prosseguir um pouco à frente com seus estudos. Este é um fator bastante desfavorável ao desenvolvimento 
rural, pois a educação é reconhecida por muitos estudiosos como essencial para o máximo aproveitamento dos conhecimentos oferecido por programas de capacitação técnica. Welch (1970) considera que trabalhadores educados são capazes de obter melhor aproveitamento dos recursos disponíveis.

Nos núcleos visitados, a grande maioria dos pais $(90,6 \%)$ declarou ser proprietária de terra, 6,3\% são arrendatários ou parceiros $\mathrm{e}$, apenas, $3,1 \%$ não possuem propriedade rural, nem contato com a terra. O tamanho das propriedades é muito variado. A grande maioria dos proprietários $(95,2 \%)$ possui até 40 alqueires, evidenciando que o programa atende, principalmente, pequenos proprietários de terra. A concentração de proprietários com, no máximo, 10 alqueires ( $84 \%$ dos proprietários) ocorre porque 3 dos 4 núcleos visitados atendem áreas de assentamento de reforma agrária.

Os produtos mais produzidos por essas famílias são milho, feijão e arroz. Estes produtos são comercializados em sua maior parte, ao mesmo tempo em que atendem às necessidades de subsistència das famílias produtoras. Os pequenos agricultores estão preocupados em produzir tanto valor de uso, como valor de troca. O milho foi o produto mais citado. Isso ocorre, segundo os agricultores, porque o cultivo do milho requer menos gastos com a produção. Em Maracaí, onde o tamanho médio das propriedades é maior e o uso da tecnologia é mais intensivo que nos outros núcleos, os produtos mais produzidos são o milho e a soja. Em Peruibe, em decorrência da pequena quantidade de áreas agricultáveis, as hortaliças, a banana e a mandioca são os principais produtos.

Apesar de pequenos e com uma estrutura agrícola de características familiares, a maior parte dos produtores $(80,3 \%)$ tem a produção voltada para o mercado, comercializando mais de $50 \%$ da produção. Somente alguns pais dos núcleos de Rancharia e Peruíbe declararam não comercializar sua produção, pois o que produzem mal dá para o sustento da família. 
A receita média bruta ${ }^{23}$ mensal das famílias entrevistadas foi de $\mathrm{R} \$ 530,00$, variando de $\mathrm{R} \$ 80,00$ a $\mathrm{R} \$ 1.500,00$ dependendo das técnicas empregadas pelas famílias. Os menores valores foram obtidos por aqueles agricultores mais tradicionais, carentes de recursos financeiros, humanos e físicos, que plantam de uma forma mais rudimentar, caso dos núcleos de Rancharia e Peruíbe. As maiores receitas vêm dos produtores mais abastados ou daqueles que possuem um giro de produção mais rápido, como horticultores e produtores de leite. Estes últimos utilizam técnicas de produção mais modernas, como ordenhadeiras, estufas e maquinário, que aumentam a produtividade. Dos pais entrevistados, $60 \%$ sobrevivem somente com o que produzem na propriedade. $O$ restante das famílias necessita desenvolver outras atividades para complementar sua renda. Destes, a maioria (44\%) presta serviços como diarista em outras propriedades.

Pelas visitas aos produtores, foi possível perceber que o nível tecnológico das famílias entrevistadas é muito desigual. Peruíbe, dos núcleos visitados, é o que apresenta maior deficiência em equipamentos agrícolas, seguido pelo núcleo de Rancharia. Maracaí demonstrou ser o núcleo que mais possui equipamentos modernos necessários à produção. Foi comum encontrar propriedades que possuíam 2 ou mais tratores. A Tabela 6.1 mostra as forças para o trabalho consideradas mais necessárias na lavoura.

Tabela 6.1 - Forças de trabalho na lavoura

\begin{tabular}{lcc}
\hline item & possui & $\%$ \\
\hline cavalo & 41 & 64,1 \\
trilhadeira & 11 & 17,2 \\
trator & 29 & 45,3 \\
implementos & 27 & 42,2 \\
ordenhadeira & 3 & 4,7 \\
colhedeira & 6 & 9,4 \\
veículo de serviço & 6 & 9,4 \\
charrete & 3 & 4,7 \\
\hline
\end{tabular}

Fonte: dados da pesquisa, 1999.

\footnotetext{
${ }^{23}$ A receita bruta é formada por todo os recebimentos obtidos com a venda da produção e a exploração das atividades desenvolvidas pelo estabelecimento sem descontar os custos de produção.
} 
No caso de Promissão, os produtores detêm individualmente baixo índice de equipamentos modernos porque possuem uma cooperativa que fornece a seus associados os serviços de máquinas e implementos agrícolas necessários ao preparo da terra, plantio, manutenção e colheita. Entretanto, nas entrevistas foi comum ouvir queixas sobre as dificuldades de utilização destes equipamentos em comum. Segundo um dos pais entrevistados, associado da cooperativa, os equipamentos nunca estão disponiveis quando se precisa deles.

Outro destaque sobre o grupo de pais entrevistados é a utilização de mão-de-obra quase exclusivamente familiar em suas propriedades. Apenas $18 \%$ das famílias contratam empregados em alguma época do ano. Por isso, a maior parte dos chefes de família (67\%) afirma que a mão-de-obra de seus filhos faz falta no trabalho quando estão no PROJOVEM ou na escola regular. Entretanto, logo após responderem essa pergunta muitos pais comentavam da importância de se freqüentar o programa e a escola, dizendo que esperam que essa falta seja recompensada pelos conhecimentos que seus filhos estão adquirindo. Pelas declarações, ficou clara a preocupação dos pais com os estudos dos filhos. Em Maracaí isto é mais evidente: $53 \%$ dos pais consideram que a mão-deobra não faz falta. Isto acontece porque é dada prioridade à educação dos jovens e os pais aceitam qualquer tipo de ajuda dos filhos desde que não atrapalhe seus estudos.

Os gastos mais freqüentes que os pais sugeriram ter com seus filhos que cursam o programa são com transporte e alimentação. Os gastos com transporte são percebidos por aquelas famílias que não permitem que as filhas durmam no núcleo e pelos jovens que moram muito distantes. Somente as famílias do núcleo de Peruíbe, dos visitados, não contribuem para a alimentação dos jovens. Os gastos com a alimentação dependem das condições financeiras das famílias, variando do equivalente a $R \$ 5,00$ a $\mathrm{R} \$ 30,00 /$ mês.

De acordo com $75 \%$ dos pais entrevistados, seus filhos não pretendem se mudar para a cidade; $12,5 \%$ (a maioria assentados) declararam que seus filhos já pensaram em se 
mudar, mas desistiram depois que entraram para o PROJOVEM e somente $12,5 \%$ admitem que seus filhos têm pretensões de sair do campo para estudar ou trabalhar.

O núcleo de Maracaí, por não atender áreas de assentamento rural, possui 31\% de suas famílias residindo em área urbana, sendo que a maioria destas famílias já residiu no campo. Este fato confirma a tendência de que cada vez mais a população rural busca a cidade e divide-se entre afazeres urbanos e agropecuários. Dados da PNAD, em1990, verificaram que $82 \%$ das famílias residentes em pequenas e médias cidades aliam o trabalho rural do pai com atividades urbanas dos outros membros da família. Entretanto, dos pais que fizeram parte da entrevista e moram no campo, $93 \%$ não querem morar na cidade, apontando como motivos mais comuns o desemprego nos centros urbanos, a crise econômica mais sentida pelos pobres da cidade que pelos pobres do campo e porque simplesmente não gostam da cidade. Os pais que moram no campo e desejam morar nas cidades $(7 \%)$, o querem porque sentem falta da comodidade oferecida pela cidade. Já os que moram na cidade, $9,4 \%$ dos pais entrevistados, se dizem satisfeitos com a vida que levam.

Para $95 \%$ dos pais, o comportamento dos jovens melhorou depois que entraram para o programa. As mudanças mais sentidas foram: melhoria no interesse pelo trabalho (citado por $80 \%$ dos pais), mais comunicativo (30\%), mais sabido (25\%), melhoria no relacionamento com a família (23\%), mais responsável (19\%), emissor de conhecimento (11\%), vontade de permanecer na terra $(28 \%)$ e melhoria do desempenho escolar $(5 \%)$.

\section{- Características e visão dos jovens}

A idade média dos jovens que freqüentam o PROJOVEM é de 17,5 anos, sendo que $92,2 \%$ possuem idade entre 14 e 21 anos, intervalo limite de idade estabelecido para que os jovens façam parte do programa. Entretanto, a maior parte dos jovens entrevistados cursa o segundo ano do programa (aproximadamente $65 \%$ dos entrevistados), indicando que eles entram para o programa com, aproximadamente, 16 anos e o concluem com 18 anos de idade. Dos jovens entrevistados, $80 \%$ são homens e apenas $20 \%$ mulheres. A 
maioria das jovens que freqüenta o programa demonstra, em suas declarações, maior interesse em aprender sobre os negócios realizados pela sua família que na implantação de um projeto de investimento, visto que o papel da maior parte delas na propriedade se restringe a cuidar da casa.

Dos jovens entrevistados, $4,7 \%$ cursaram a escola até completar o primário. O restante conseguiu se manter na escola por mais tempo. Até o momento da entrevista, 25,1\% estavam cursaram ou cursou até o primeiro grau, $53,1 \%$ tinham cursado ou estavam cursando o segundo grau e $17,2 \%$ tinham concluído o segundo grau e parado de estudar. Dos $43(67 \%)$ jovens que ainda freqüentam a escola regular, 53,5\% declararam que seu desempenho nos estudos melhorou depois que entraram para o PROJOVEM, enquanto os outros $46,5 \%$ afirmaram que seu desempenho continua o mesmo que antes. A grande maioria dos jovens estuda no período noturno para não atrapalhar o trabalho durante $o$ dia, sendo que $75 \%$ dos jovens trabalha mais de 6 horas por dia.

$\mathrm{Na}$ visão da maior parte dos jovens (66\%), as únicas coisas úteis que aprendem na escola regular e que podem aproveitar no seu trabalho são ler, escrever e calcular. Outros $14 \%$ sugeriram que aprenderam nada ou quase nada. Entretanto, 20\% considera que tudo que aprendem na escola, um dia, poderá ser útil.

Os jovens buscam no PROJOVEM aprender o que realmente necessitam para se desenvolver técnica e economicamente no campo. Eles vêem no programa a possibilidade de preencher a lacuna deixada pela escola regular, de caraterísticas predominantemente urbanas. Dos jovens, $40 \%$ declararam ter entrado para o programa para desenvolver um projeto e melhorar de vida, 36\% para aprender novas técnicas, $14 \%$ por curiosidade ou insistência dos pais e $10 \%$ para ser empresário rural.

Os jovens do meio rural não têm muitas opções de ensino voltado ao setor. Uma das poucas alternativas educacionais são as escolas agrotécnicas. $\mathrm{O}$ tipo de ensino oferecido por estas escolas visa o aumento da produtividade e a difusão de novas técnicas de produção no setor agrícola (Alves Filho, 1976). Este tipo de ensino, enquanto se propõe 
a formar agentes de mudanças no setor rural, deveria ter sua atenção voltada principalmente para o atendimento dos jovens desse setor. Entretanto, vários autores constataram que grande parte dos alunos atendidos por estas escolas não possui atividades ligadas ao setor nem pretende ter. Alves Filho (1976), verificou que 82\% dos jovens que freqüentavam escolas agrícolas no Estado de São Paulo em 1974, pretendiam continuar seus estudos à nível superior, especialmente profissões ligadas a ocupações liberais. De maneira similar, Mello, Peres \& Toyama ${ }^{24}$ constataram que os problemas identificados por Alves Filho nos anos 70 ainda persistem nos dias de hoje.

Dos jovens que freqüentam o PROJOVEM, 51,6\% responderam que gostariam de cursar a escola agrotécnica. A principal justificativa para isso, apontada por $84 \%$ dos jovens, é que eles aprenderiam muito mais sobre a terra. $O$ restante $(16 \%)$ sugere que o curso agropecuário poderia ajudá-los a arrumar emprego. Entre os $48,4 \%$ dos jovens que não manifestaram o desejo de cursar a escola agrícola, as justificativas mais utilizadas foram que o PROJOVEM já ensina o suficiente para o tipo de trabalho que terão que realizar (37\%); nunca pensaram em fazer escola agrícola (26\%); não pode ou não gosta de ficar fora de casa por muito tempo (20\%); e o restante sugeriu que a escola agrícola forma empregados $(17 \%)$.

Das técnicas ensinadas no programa (Tabela 6.2), nem todas são colocadas em prática pelos jovens. A principal dificuldade, apontada por $36 \%$, é a falta de recursos financeiros. Outros fatores limitantes foram citados pelos entrevistados: $13 \%$ declararam ser difícil convencer os pais a aceitar novas idéias; $10 \%$ sugeriram não saber como fazer várias das técnicas que aprenderam no programa; $8 \%$ têm dificuldades com cálculo; e 7\% declararam que o relevo e a vegetação de suas propriedades dificultam a adoção de novas técnicas. Apesar disso, $26 \%$ dos jovens afirma não possuir nenhuma dificuldade em praticar o que aprendem no PROJOVEM.

\footnotetext{
${ }^{24}$ Conforme autores citados na página 41 .
} 
Tabela 6.2 - Técnicas aprendidas ou aperfeiçoadas pelos jovens no PROJOVEM

\begin{tabular}{llc}
\hline técnica & $\mathrm{n}^{\circ}$ & $\%$ \\
\hline adubação orgânica & 54 & 84,4 \\
perigo da utilização de & & \\
defensivos & 40 & 62,5 \\
combate às pragas & 54 & 84,4 \\
conservação do solo & 56 & 87,5 \\
fertilização do solo & 49 & 76,6 \\
preparação do solo & 60 & 93,8 \\
pesquisa de mercado & 60 & 93,8 \\
projeto de investimento & 60 & 93,8 \\
\hline
\end{tabular}

Fonte: dados da pesquisa, 1999.

Dos jovens entrevistados, $33 \%$ não têm idéia do projeto que irão realizar. O restante (67\%), iniciou seus estudos e já possui expectativas em torno da renda que espera obter com seus projetos. A renda bruta esperada oscila entre $\mathrm{R} \$ 200,00$ e $\mathrm{R} \$ 1.400,00 / \mathrm{mês}$, sendo que $12 \%$ dos entrevistados espera receber entre $R \$ 200,00$ e $R \$ 400,00,35 \%$ entre $R \$ 400,00$ e $R \$ 600,00,35 \%$ entre $R \$ 600,00$ e $R \$ 800,00,16 \%$ entre $R \$ 800,00$ e $\mathrm{R} \$ 1.000,00$ e $2 \%$ entre $\mathrm{R} \$ 1.200,00$ e $\mathrm{R} \$ 1.400,00 / \mathrm{mês}$.

O programa orienta os jovens para que se tornem empresários rurais eficientes. Burke (1998), em sua avaliação pedagógica sobre o programa, considerou a utilização de um projeto de investimento suficiente para que os jovens aprendam a planejar e decidir sobre a viabilidade de uma atividade antes de executá-la. Dos jovens entrevistados, apenas $3 \%$ não sabem como fazer um projeto e $6 \%$ não sabem como calcular o retorno de um projeto.

Todos os jovens declararam que com o término do curso serão empresários rurais. As respostas à pergunta "o que é um empresário rural" dividiram-se basicamente em dois grupos: $50 \%$ responderam que empresário é quem elabora um projeto, coloca-o em prática e administra-o a fim de ganhar dinheiro; para $45 \%$ dos entrevistados, empresário é quem tem seu próprio negócio e vive dele e para $5 \%$, empresário é quem procura melhorar financeiramente. 
Quando perguntado ao jovem se o pai utiliza o cálculo do retorno em sua propriedade, $55 \%$ responderam afirmativamente. Dentre esses, muitos comentaram que essa prática só passou a ser utilizada em sua propriedade depois que entraram para o PROJOVEM ou, quando utilizada, não era detalhada. Dos jovens que praticam essa técnica, $92 \%$ o fazem para saber se terão lucro ou prejuízo com uma atividade. Dos jovens que não utilizam o cálculo do retorno, $58 \%$ não sabem como fazer direito, $24 \%$ porque os pais não acham necessário e $18 \%$ sugeriram que a situação financeira da família é tão ruim que nem é necessário este tipo de cálculo.

A melhor forma de um pequeno produtor ganhar dinheiro, na opinião de $89 \%$ dos entrevistados, é diversificando a produção. Destes, $65 \%$ declararam que conseguem o objetivo diversificando as atividades - um produto pode compensar algum outro que não tenha tido boa produção - além de possuírem produtos para vender o ano inteiro. $\mathrm{O}$ restante sugeriu que a diversificação de produtos impede o empobrecimento do solo.

Quando perguntados sobre os problemas do País, eles concordaram que tanto nas cidades quanto no campo, a sociedade vem se defrontando com inúmeros problemas sociais, como violência, fome, invasões de terra etc.. Na opinião de $36 \%$ dos jovens, o governo é o culpado pela existência destes problemas, para $34 \%$ a culpa é do desemprego, 16\% acusam a ganância dos homens e $14 \%$ a desorganização e a desinformação da sociedade.

Quando perguntados sobre a importância da associação entre pequenos produtores, $85 \%$ concordam que é importante. Destes, a resposta de $68 \%$ dos entrevistados sugeriu que formando uma associação os produtores podem comprar insumos mais baratos e vender seus produtos a melhores preços. O restante sugeriu que o trabalho em associação é menor e melhor, pois um produtor ajuda o outro. Os jovens que não aprovam a associação entre produtores declararam que é melhor não depender de outras pessoas para executar um trabalho. Muitos comentaram que "associação é bom desde que seu sócio seja de confiança". 
Dos jovens entrevistados, $78 \%$ pretendem continuar vivendo e trabalhando no meio rural. O restante pretende continuar seus estudos à nível superior. As profissões a serem seguidas pela maioria destes jovens estão ligadas ao meio urbano, como: advogados, militar, médico, dentista etc. Apenas $28,6 \%$ dos jovens que pretendem fazer curso superior desejam dedicar-se a áreas relacionadas à agropecuária. Traçando uma rápida comparação com o estudo de Mello, Peres \& Toyama ${ }^{25}$, dos jovens que freqüentam as escolas agrícolas estudadas, $40 \%$ desejam fazer cursos superiores. Destes, só $14 \%$ pretendem estudar atividades relacionadas ao campo.

Algumas modificações no estilo de vida dos jovens que freqüentam o programa foram percebidas rapidamente. Entretanto, essas mudanças são de caráter comportamental e social. Alterações na situação econômica das famílias são mais demoradas e foram citadas por poucos jovens. As modificações mais citadas foram: maior interesse pelo trabalho $(76,6 \%)$, mais amizades $(45,3 \%)$, mais comunicativo $(53,1 \%)$, mais responsável $(26,6 \%)$, melhor convívio familiar $(25 \%)$, mais conhecimentos $(25 \%)$, melhor desempenho escolar $(17,2 \%)$ e mais crítico $(15,6 \%)$.

\section{- Características e visão dos monitores}

De acordo com 8 dos 9 monitores entrevistados, a função do monitor é orientar os jovens de forma a torná-los empresários rurais. Para isso, o PROJOVEM dispõe de profissionais com conhecimentos específicos na área agropecuária. Dos 9 monitores entrevistados, 5 são técnicos agropecuários, 3 são agrônomos e 1 é zootecnista. Além de monitores do programa, 5 dos entrevistados são empresários rurais, 2 já executaram projetos na área rural e outros 2 declararam não possuir nenhum tipo de experiência em empreendimentos rurais. Apesar de alguns monitores exercerem outras atividades além do PROJOVEM, 5 deles sugeriram estar o tempo todo à disposição do programa e 4 afirmaram que dedicam $75 \%$ do seu tempo ao PROJOVEM.

\footnotetext{
${ }^{25}$ Conforme autores citados na página 41 .
} 
Quando perguntado aos monitores se o construtivismo era o melhor método para se trabalhar com jovens carentes do meio rural, 7 responderam que sim. Destes, 5 monitores acreditam que aprendizagem motivada por suas necessidades é o que mais atrai o jovem no programa. Outros 2 monitores acreditam que o construtivismo une os jovens e estimula o envolvimento das famílias na aprendizagem. Apenas 2 monitores sugeriram que o construtivismo não é totalmente eficiente para a finalidade do programa. Estes monitores consideram muito dificil trabalhar com alunos que possuem baixo nível educacional. Na opinião de um deles, falta mais estudo formal para que estes jovens aproveitem melhor o curso oferecido pelo PROJOVEM.

No que se refere à Associação Central de Pais (ACP), apenas 2 monitores sugeriram que ela não está preparada para assumir todas as responsabilidades sobre o PROJOVEM. A maioria, 7 monitores, declarou que a ACP é capaz de gerir o programa, mas com o apoio da Assessoria. Destes, 5 monitores consideraram que a ACP, composta por pequenos proprietários, é inexperiente na administração de um grande projeto como o PROJOVEM, 1 declarou que a ACP ainda não entende o que é PROJOVEM e o último que a ACP tem muito poder, mas não sabe o que acontece dentro dos núcleos.

Todos os entrevistados declararam que os cursos de capacitação são muito importantes para a formação dos monitores. Nestes cursos, os monitores são colocados na posição dos jovens: sanam suas dúvidas, aprendem com a experiência de outros monitores e da assessoria. Na opinião de 8 dos 9 monitores entrevistados, sem os cursos de capacitação existe a possibilidade de o ensino deixar de ser construtivista, ou seja, existe o risco dos monitores tornarem-se simples professores.

A maior preocupação que aflige 5 dos monitores entrevistados é a insegurança em relação à aplicação do construtivismo, pois eles não sabem se o que estão fazendo está certo ou errado. A Assessoria, por falta de tempo, dinheiro e pessoal, não consegue fazer um acompanhamento das atividades dos monitores dentro dos núcleos. Outros 3 têm como maior preocupação o envolvimento dos pais. De acordo com um dos monitores, 
poucos pais pensam no PROJOVEM como sendo deles. Somente um dos entrevistados admitiu que o contrato de trabalho dos monitores provoca instabilidade e insegurança quanto ao futuro, prejudicando seu trabalho. O CEETEPS dispensa os serviços dos monitores depois de 2 anos de trabalho, podendo recontratá-los somente depois de um periodo de 6 meses.

Na opinião de 8 dos monitores o PROJOVEM está formando empresários rurais, pois os jovens que freqüentam o programa demonstram estar interessados em montar projetos para ganharem seu próprio dinheiro. Apenas 1 dos monitores ponderou que nem todos os jovens serão empresários rurais, pois não existe garantia que aqueles que freqüentam o programa permanecerão no campo. Entretanto, não é necessário que o jovem permaneça no campo para ser um empresário. $O$ jovem pode morar na cidade e ter alguma atividade ligada ao campo como, por exemplo, feirante, lojista de produtos agropecuários, dono de uma propriedade rural etc.. Dessa forma, mesmo na cidade, os jovens estariam utilizando os conhecimentos adquiridos no PROJOVEM para montar e continuar seu projeto.

Os monitores consideram que o PROJOVEM trouxe beneficios para os jovens e suas famílias. Entretanto, as modificações mais percebidas até agora foram as mudanças de comportamento. Para os monitores, muitas das mudanças comportamentais conseguidas pelo programa terão implicações sobre a situação financeira das famílias no futuro. As modificações mais citadas pelos monitores foram: aumento do interesse pelas atividades oferecidas pelo programa; melhoria do diálogo; vontade de permanecer na terra; melhor relacionamento com a família; vontade de realizar projetos e maior integração com a comunidade.

Quando perguntado sobre o relacionamento entre os monitores, eles concordaram que quando duas ou mais pessoas trabalham juntas podem ocorrer divergências de idéias. Eles consideram isto natural e até saudável, desde que não interfira no cumprimento do trabalho, gerando problemas de relacionamento entre os envolvidos. De acordo com os 
monitores entrevistados, entre eles não existem conflitos de relacionamento, existem apenas conflitos de idéias que contribuem para a qualidade do trabalho.

Quase todos os entrevistados declararam que o PROJOVEM tem capacidade de melhorar as condições de vida das famílias envolvidas. Apenas um dos nove monitores não acredita nesta possibilidade porque acha que os jovens precisam de informações além das que o programa ensina. Para os 8 monitores que acreditam que o PROJOVEM é suficiente para melhorar a vida dos envolvidos, 4 deles declararam ser necessário interesse do jovem para que isso aconteça, 3 acreditam na possibilidade de melhoria de vida porque no PROJOVEM o jovem aprende a planejar atividades diminuindo as possibilidades de erro e 1 porque eles repassam para a família o que aprendem no programa.

Terminada esta etapa, foi possível verificar que a população atendida corresponde à população esperada pelos idealizadores do programa. Tanto os pais como os jovens e monitores acreditam que a metodologia utilizada pelo programa é capaz de formar empresários rurais com capacidade de desenvolver suas próprias atividades, contribuindo para a melhoria do padrão de vida das famílias integrantes.

\subsection{As respostas às questões de investigação levantadas}

A revisão de literatura permitiu que algumas questões sobre o PROJOVEM e as pessoas diretamente envolvidas com o programa fossem levantadas. Nesta parte do trabalho estas questões serão tratadas uma a uma.

1- Os jovens percebem a diferença entre o tipo de ensino promovido pelo PROJOVEM e pelas escolas tradicionais?

Os resultados obtidos durante o período de pesquisa mostraram que a maioria dos jovens percebe a diferença entre o tipo de educação oferecido pelas escolas tradicionais e pelo PROJOVEM. Foram citadas várias diferenças entre os dois tipos de escolas, mas a principal diferença, observada por $47 \%$ dos entrevistados, é que no PROJOVEM eles 
aprendem aquilo que têm necessidade e será utilizado no seu dia-a-dia, enquanto na escola regular aprendem coisas distantes da sua realidade. Depois vieram várias respostas: $26 \%$ dos jovens sugeriram que no programa aprendem por meio da prática e troca de experiência, 9\% consideram o PROJOVEM uma família, 7\% disseram que o monitor não dá respostas, eles têm que buscá-las, $6 \%$ declararam aprender só sobre agricultura e, somente 5\% não vêem diferença entre as duas escolas.

As respostas da maioria dos jovens associam ensino, capacitação e meio rural. Uma das respostas obtidas ainda mostra claramente a percepção dos jovens quanto à utilização pelo programa da concepção construtivista de ensino. É interessante mencionar que o grupo de jovens ( $5 \%$ dos entrevistados) que não identificou nenhuma diferença entre as escolas pertence ao mesmo núcleo. Esse fato provavelmente se deve a dois fatores: o primeiro, por deficiência de alguns monitores que encaram o programa apenas como um emprego e não acreditam na idéia do PROJOVEM, ou seja, não acreditam que por meio da alternância, construtivismo e planejamento e implantação de um projeto os jovens tornar-se-ão empresários rurais. O segundo motivo pode ter sido gerado pelos mobilizadores que não conseguem identificar os jovens que possuem perfil de acordo com o exigido pelo programa. Os mobilizadores, normalmente candidatos a monitores, estão, às vezes, preocupados em atingir o número mínimo de jovens para a abertura de uma nova turma e consolidar a continuidade do seu núcleo e, com isso, de seu emprego.

2. O PROJOVEM estimula a troca de informações entre pais e filhos, impedindo uma interrupção cultural e tecnológica entre as gerações?

No que se refere à troca de informações, foi possível constatar a dificuldade dos pais em aceitar as novas técnicas aprendidas pelos filhos no PROJOVEM. Pouco mais da metade dos pais que possuem terra utiliza alguma coisa que seu filho tenha aprendido no programa. A maior parte passou a planejar a produção contabilizando todas as entradas e saídas de dinheiro. Dos pais que não praticam, $60 \%$ responderam que faz pouco tempo 
que seus filhos entraram para o programa e o restante não possui dinheiro para fazer o que eles aprendem. Mesmo assim, em resposta a uma pergunta aberta, 11\% dos pais responderam espontaneamente que seus filhos tornaram-se emissores de conhecimento, passando para os outros membros da família aquilo que aprendem no PROJOVEM.

Pelo lado dos jovens, uma das dificuldades apontada voluntariamente por $13 \%$ para a colocação em prática do que aprenderam no PROJOVEM é convencer o pai a aceitar novas idéias. Outra constatação dessa dificuldade é que $24 \%$ dos jovens declararam não utilizar o cálculo do retorno no planejamento das atividades porque o pai não acha necessário. Mesmo com toda a resistência dos pais em praticar o que seus filhos aprendem no PROJOVEM, 95\% dos jovens entrevistados repassam para a família tudo que aprendem nas semanas de núcleo. Além disso, 77\% dos jovens afirmam que seu relacionamento com a família melhorou depois que entraram para o programa. Destes, $33 \%$ conversam muito sobre o que aprendem no programa, $23 \%$ afirmam que a família está mais unida e $44 \%$ passaram a participar das decisões familiares. Estes fatos ocorrem porque o PROJOVEM não separa o jovem do seu trabalho e meio ambiente cultural familiar durante o seu processo de formação (Peres et al., 1998).

Em relação à resistência dos pais em aceitar as inovações trazidas pelos jovens, é interessante notar que as famílias mais desprovidas de recursos e inexperientes com atividades agropecuárias são as que aceitam mais facilmente as mudanças trazidas pelos jovens. Normalmente, os chefes destas famílias não possuem tanto conhecimento formal quanto os pais mais abastados, levando-os a valorizar mais o aprendizado dos filhos.

3. Quais as diferenças entre o PROJOVEM e outros programas que utilizam a pedagogia de alternância?

A pedagogia de alternância é utilizada por diversos programas educacionais destinados a modificar as condições de vida dos jovens no meio rural. A maioria destes programas está preocupada em ensinar, principalmente, conhecimentos ou pacotes técnicos. 
Entretanto, a maioria dos jovens atendidos por estes programas é proveniente de áreas rurais carentes, nas quais as famílias não têm como aplicar aquilo que seus filhos aprendem. O PROJOVEM, por meio da identificação dessa falha nos outros programas, orientou seus monitores a ensinar técnicas acessíveis e poupadoras de recursos e, quando isso não é inteiramente possível, o PROJOVEM disporá de um fundo rotativo que financiará os projetos dos jovens que necessitem de ajuda financeira para implantálos.

É importante ressaltar que o crédito no PROJOVEM faz parte da pedagogia e é necessário para a finalidade do programa de transformar jovens em empresários rurais. Toda aprendizagem recebida no programa gira em torno da realização de um projeto de investimento individual. Este projeto tem duas funções: enquanto o jovem planeja detalhadamente seu projeto, aprendendo a calcular custos e retornos e a melhor forma de gerenciá-lo, ele aprende matemática, português, adquire conhecimentos de química e biologia, etc.. Além disso, um projeto bem executado pode se tornar uma fonte de renda a mais para a família, proporcionando uma melhoria na qualidade de vida. A execução de projetos bem planejados pode até melhorar as condições econômicas e sociais das famílias, mas a intenção do programa é que o desenho e implantação do primeiro projeto sirva de modelo para todos os empreendimentos realizados pelos jovens ao longo de suas vidas. Com o uso do construtivismo ele deve aprender a aprender, em vez de receber pacotes tecnológicos acabados.

\section{Os pais dos jovens que freqüentam o PROJOVEM aceitam o uso do termo "empresário" para caracterizar seu trabalho?}

Os resultados indicaram que aproximadamente metade dos produtores entrevistados (46\%) não se considera empresário rural. Muitos não sabem o que significa, mas a maioria dos pais sabe o que é empresário rural, mas não se enxerga como um. Alguns pais, dentre os que rejeitam o termo, chegam a descrever suas próprias funções dentro 
de suas propriedades, mas recusam o termo empresário rural.

Quando perguntado aos pais o que é um empresário rural, 33\% responderam que é aquele que sabe o que produzir, pesquisa o mercado para saber preço, local de comercialização e demanda; para $20 \%$, empresário é quem vive do que produz; e para $8 \%$, empresário é quem tem tudo na ponta do lápis. O restante respondeu de diversas formas, fugindo das definições aceitáveis sobre o que é ser empresário rural. Mesmo alguns pais que parecem estar mais engajados no PROJOVEM consideram-se apenas agricultores. Muitos dos pais entrevistados associam a palavra empresário a atividades urbanas de sucesso. Para eles, a palavra empresário está diretamente relacionada a dinheiro e como eles não possuem muito dinheiro, não são empresários.

5- O nível de escolaridade dos pais interfere positivamente no nível de escolaridade dos filhos?

Dos pais entrevistados, $80 \%$ possuem no máximo o primário completo, sendo que destes, $11 \%$ não possuem instrução formal e, somente $11 \%$ dos pais concluíram o segundo grau. Pelo lado dos jovens, $70 \%$ completaram no mínimo o primeiro grau, sendo que $17 \%$ destes concluíram o segundo grau. Os dados, por si só, demonstram que o nível de escolaridade dos filhos é maior que o dos pais. Isso ocorre porque os pais, desconfiados da pouca segurança proporcionada pela posse da terra, estão dando mais valor à educação, exigindo que seus filhos estudem por mais tempo e acompanhem a evolução tecnológica para continuarem sobrevivendo da agropecuária.

No caso desta pergunta (5), pode-se verificar a correlação existente entre as variáveis escolaridade dos pais e escolaridade dos filhos pela aplicação do teste de correlação de Spearman. Este teste é apropriado para dados ordinais. O valor absoluto do coeficiente de correlação indica a força da relação entre as variáveis, com valores absolutos maiores indicando relações mais fortes. $O$ sinal do coeficiente indica a direção da relação. $O$ coeficiente encontrado para essa questão foi de $-0,045$, indicando uma fraquíssima correlação negativa entre as variáveis da amostra, o que permite afirmar que 
praticamente não existe correlação entre as variáveis analisadas. Para confirmar este resultado, verifica-se que, ao nível de significância de 0,05 e com uma amostra de tamanho 64, necessita-se de um $r_{s}$ calculado, no mínimo, maior que o $r_{s}$ crítico fornecido pela tabela e a probabilidade disso não acontecer é muito alta: $72 \%$.

6- Famílias que vivem há mais tempo no meio rural possuem melhor situação econômica (ou seja, maiores rendimentos) que as famílias que ali estão há menos tempo (especialmente os assentados)?

O PROJOVEM atende, principalmente, filhos de pequenos produtores e trabalhadores rurais experientes, ou seja, são famílias tradicionalmente ligadas à terra. A média de permanência destas famílias no campo é de 33 anos. Dos entrevistados, 36\% sempre viveram ou trabalharam no campo, 50\% vivem há mais de 36 anos e apenas $14 \%$ estão há menos de 10 anos no campo. O núcleo de Rancharia, por atender famílias recentemente assentadas, possui aproximadamente $80 \%$ dos pais entrevistados vivendo há no máximo 8 anos no meio rural. A maioria é formada por ex-trabalhadores rurais e urbanos despreparados para o processo de gestão da unidade agrícola.

A receita média bruta mensal declarada em 1998 pelos pais entrevistados foi de $\mathrm{R} \$ 530,00$, equivalente a quase 4 salários mínimos. Todavia, existe uma discrepância muito grande entre a menor $(\mathrm{R} \$ 80,00)$ e a maior receita $(\mathrm{R} \$ 1.500,00)$ percebida pelas famílias. A utilização do teste de Spearman confirmou a existência de uma fraca correlação positiva entre tempo de permanência e receita das familias entrevistadas. $O$ valor do coeficiente de correlação encontrado para a amostra foi de 0,17 . No nível de significância de 0,05 e para uma amostra de tamanho 61 , a probabilidade do $r_{s}$ calculado ser maior do que o $\mathrm{r}_{\mathrm{s}}$ crítico é de $18 \%$, indicando que a hipótese nula que "não existe correlação entre as variáveis" é aceita.

7- Pais que possuem maior escolaridade formal são os que detêm maiores niveis de rendimento? 
Essa é uma questão clássica da Teoria do Capital Humano. Para verificar sua validade para essa amostra foi aplicado o mesmo teste usado nas hipóteses cinco e seis , o Teste de Correlação de Spearman.

O resultado do teste reforça a indicação que indivíduos mais estudados são os que obtêm mais altos rendimentos. Dos trinta e quatro pais que percebem rendimentos mensais brutos menores que $\mathrm{R} \$ 500,00$, vinte e seis deles possuem no máximo o primário completo. O coeficiente de correlação de 0,35 indica que escolaridade e renda estão positivamente correlacionados, ou seja, aumentando a escolaridade aumenta-se o nivel de rendimento dos indivíduos. Além disso, verifica-se que ao nível de significância de 0,05 e com uma amostra de 57 respondentes, necessita-se de um $r_{s}$ calculado, no mínimo, maior que o $r_{s}$ crítico fornecido pela tabela e a probabilidade disso não acontecer é muito baixa: $0,08 \%$. Portanto, os resultados podem ser estendidos a toda a população da qual a amostra foi retirada. Com isso, pode-se concluir que indivíduos que passaram mais tempo se educando percebem maiores rendimentos. Esse resultado pode ser explicado considerando-se que ao se educar os individuos modificam o aproveitamento dos recursos existentes, aumentando sua eficiência produtiva e, com isso, seus rendimentos. Segundo Welch (1970), a escolaridade facilita a absorção e decodificação das informações a respeito dos custos e das propriedades produtivas de novas tecnologias e insumos agropecuários.

\section{8- O tipo de educação oferecida pelo PROJOVEM tende a fixar o} jovem no campo?

A intensidade da migração rural-urbana permanece praticamente a mesma desde 50 anos atrás. De acordo com Abramovay (1997), desde 1950, a cada 10 anos, um em cada três brasileiros que vive no meio rural opta por migrar para o setor urbano e, durante os anos 90 , a faixa etária que mais migrou esteve concentrada entre as idades de 20 a 24 anos. As dificuldades impostas pela falta de políticas públicas de incentivo à agricultura familiar e pela adoção de tecnologias poupadoras de mão-de-obra impedem as famílias 
de levar uma vida digna no campo e impulsionam os mais jovens a se aventurar nas cidades, engrossando a massa de desempregados ou se dedicando a empregos de baixa qualificação e remuneração.

Para fazer parte do PROJOVEM o jovem tem que estar disposto a permanecer na área e ter vocação para a atividade rural, pois tudo que aprende no programa está direcionado para transformar o jovem num empresário rural (da agropecuária ou da área de serviços). Confirmando a expectativa do programa em contribuir para a fixação do jovem no campo, a maioria dos pais (75\%) afirmou que seus filhos não pensam em se mudar para as cidades, $12,5 \%$ admitiram que seus filhos já pensaram, mas desistiram depois que entraram para o PROJOVEM e somente $12,5 \%$ dos pais responderam que seus filhos pensam em se mudar para a cidade para trabalhar ou continuar seus estudos (destes, a maioria é de Rancharia). É interessante notar que alguns pais apóiam e incentivam essa decisão. Muitos deles chegam a se mostrar decepcionados pela escolha dos filhos em permanecer na terra, afirmando que não queriam para os filhos o mesmo destino que tiveram. Para os pais, existem profissões menos sacrificantes, bem remuneradas e com um status maior que o de agricultor. Por outro lado, os jovens que freqüentam o programa pretendem, em sua maioria, permanecer no campo depois de concluído o curso. Muitos destes jovens vêem no PROJOVEM a chance de melhorar de vida. Isto fica evidente pela resposta de $78 \%$ dos jovens que pretendem continuar vivendo e trabalhando no campo. Outros $9 \%$ pretendem seguir profissões urbanas (direito, militar, informática, letras, medicina, odontologia etc.) e o restante, estudar profissões ligadas ao campo (agronomia, técnico agropecuário e ciências biológicas). Apesar de alguns jovens desejarem profissões urbanas, todos eles sabem que o ensino oferecido pelo programa só serve para quem quer ser empresário rural. Quase todos os entrevistados $(98,4 \%)$ concordaram que o aprendizado que adquirem no PROJOVEM lhes será mais útil no meio rural.

Grande parte dos jovens que pretende continuar estudando pertence ao núcleo de Maracaí. Como dito anteriormente, este núcleo possui mais de $30 \%$ dos jovens residindo 
em área urbana. Além disso, a região sofre influência de imigrantes europeus (alemães e italianos), que dão muita importância ao estudo conciliado ao trabalho. Outro fato que pode explicar esse número elevado de jovens que pretende sair de suas propriedades para estudar é uma mobilização mal feita que não identificou adequadamente os jovens alvos do programa.

9- A demanda pelo programa é maior entre os filhos de proprietários de terra que entre filhos de parceiros, arrendatários e trabalhadores rurais?

Nos núcleos visitados, a grande maioria dos pais $(90,6 \%)$ declarou ser proprietário de terra, $6,3 \%$ declararam ser arrendatário ou parceiro e apenas 3,1\%, não possuírem propriedade rural, nem contato com a terra. Estes últimos são moradores e empregados do setor urbano de Maracaí. Dentre os proprietários de terra, 95,2\% possuem propriedades com menos de 40 alqueires. Prazeres (1976) aponta que essa classe de área (pequenos proprietários) é propensa à adesão em massa aos programas de capacitação. Na visão dessa autora, estes pais estão em situação desfavorável em relação aos demais, e portanto, são predispostos a novos arranjos de exploração da terra.

10- Os pais que possuem filhos no programa participam diretamente da educação de seus filhos?

Pelas entrevistas foi possível perceber o envolvimento dos pais com o programa. A maioria dos pais (86\%) afirmou ter contato permanente (no mínimo uma vez por mês) com os monitores, $60 \%$ já visitaram o núcleo e $70 \%$ declararam frequentar as reuniões da Associação local. Durante as reuniões os assuntos mais discutidos são os problemas ocorridos na semana de núcleo (comportamento e alimentação), o que foi visto na semana de alternância e o que será estudado na próxima. Apesar da participação maciça de pais, muitos deles não querem assumir compromissos. $O$ papel deles se restringe a um acompanhamento sobre o que acontece na semana em que seus filhos estão em 
núcleo. Na opinião dos pais, eles não são mais atuantes devido à falta de tempo e à distância que têm de percorrer entre suas casas e o núcleo.

Do ponto de vista dos monitores, a participação dos pais no programa ainda é insuficiente. Para eles, a maioria dos pais ainda não entendeu sua função e suas responsabilidades dentro do programa e, por isso, não assumiu sua condição de "dono" do programa. $\mathrm{Na}$ opinião de alguns monitores, os pais estão acostumados a "esperar tudo cair do céu" e o processo de mudança dessa mentalidade é muito lento.

11- Os monitores consideram os cursos de capacitação suficientes para o exercício de orientador do aprendizado do jovem?

Todos os monitores consideraram os cursos de capacitação essenciais para a formação do monitor. Para 2 dos 9 monitores entrevistados, os cursos são importantes porque proporcionam momentos para trocas de experiências entre os monitores sobre os problemas comuns que ocorrem nos núcleos. Os outros 7 consideraram que nestes encontros a Assessoria da ACP os ensina, de maneira construtivista, como eles devem agir nos núcleos.

Somente um dos entrevistados considera-se capaz de prosseguir o programa sem os cursos de capacitação, admitindo que existe a possibilidade de fugir do construtivismo. Todos os outros monitores declararam que sem os cursos de capacitação o programa perderia uma de suas bases de sustentação, pois eles deixariam de ser construtivistas e passariam a ser apenas transferidores de tecnologia. Dos 8 monitores que não se consideram capazes de prosseguir com o programa sem os cursos de capacitação, todos sugeriram não ter conhecimentos suficientes ou experiência para prosseguir na linha construtivista. Na opinião destes monitores, sem capacitação eles se transformariam em simples transmissores de conhecimentos.

Apesar de os monitores confiarem no construtivismo como instrumento capaz de transformar jovens carentes em empresários rurais, eles não agem (como não agiam há 
um ano, Burke, 1998) de uma maneira suficientemente construtivista. Os monitores até se esforçam, mas sua formação construtivista ainda é insuficiente para conseguirem que os jovens aprendam internalizando as informações e construindo seus conhecimentos. Isto foi observado pela incoerência entre a descrição pelos monitores de uma atividade de trabalho e a maneira como eles realmente a aplicam, não atingindo o objetivo da atividade ou dando a resposta ao jovem. Todos os monitores descreveram atividades que se bem trabalhadas poderiam contribuir para a construção do saber do jovem, entretanto, eles se perdem na aplicação da atividade. De acordo com os monitores, a Assessoria da ACP deveria fazer uma supervisão das atividades de núcleo com mais efetividade. Só assim as falhas poderiam ser corrigidas mais rapidamente.

A análise realizada até agora neste capítulo permite concluir que as pessoas envolvidas no programa (pais e jovens) fazem parte de uma parcela-da-população-carente de recursos financeiros, assistência social e técnica. São famílias frutos de um sistema partenalista e tradicional, conformadas em esperar "ajuda dos céus". Essas famílias são exemplos de que de nada adiantaria oferecer dinheiro a elas sem um suporte técnico, organizacional e educacional por trás.

A confirmação de algumas questões mostra que o PROJOVEM está iniciando um processo de mudança no campo, oferecendo educação e capacitação voltados ao meio rural, favorecendo a troca de informações entre as pessoas sem provocar choque de cultura entre elas, disponibilizando recursos que viabilizem a implantação dos projetos e contribuindo para a fixação dos jovens no campo.

Resumidamente, depois de três anos de funcionamento do programa, pode-se descrever um cenário de vida diferente para muitas famílias e jovens. Na primeira visita aos núcleos, em março de 1998, feita em companhia de um especialista em extensão rural e construtivimo com o objetivo de avaliar a pedagogia empregada pelo programa, o que se viu foi muita incerteza por parte dos pais em relação ao futuro do programa e dos 
jovens, muita pobreza e jovens que tinham vergonha de pronunciar até seus nomes. Hoje, fatos concretos demonstram que o programa, mesmo com algumas falhas, consegue cumprir o papel de disseminador de tecnologia e manutenção dos jovens rurais junto às suas famílias. Como declarou um dos pais entrevistados, “agora está mais fácil lidar com os jovens. Meu filho, assim como o resto dos meninos, tomou gosto pelo trabalho".

Os dados obtidos permitem visualizar que tanto o nível de vida como as condições de produção dos pequenos produtores envolvidos no programa são muito diferentes. Existem produtores com melhores condições financeiras, detentores de tecnologia e que aplicam técnicas modernas de produção. Por outro lado, existem produtores que sobrevivem em condições de penúria, com falta de recursos e tecnologia para desenvolver suas atividades.

Verificou-se que a grande maioria dos produtores entrevistados dedica-se há muito tempo a trabalhos no campo e, pouco a pouco, vem buscando modernizar as técnicas de produção e administração da propriedade rural. Este fato pode ser evidenciado pela melhora nas condições de vida de muitos pequenos produtores (principalmente assentados), pela formação de cooperativas fornecedoras de equipamentos rurais e pela aceitação de novas alternativas capazes de desenvolver o meio rural.

A utilização de algumas técnicas ensinadas pelo PROJOVEM já tem apresentado resultados positivos: aumento da produção (citado por $6,2 \%$ dos pais entrevistados), diminuição dos gastos com defensivos e fertilizantes (citado por 9,3\%), melhor aproveitamento dos recursos existentes na propriedade (citado por $12 \%$ dos pais), introdução de novas culturas (citado por $18,75 \%$ dos pais) etc.. As mudanças são mais perceptíveis nas famílias mais carentes. Propriedades que há um ano eram monocultoras ou não haviam nada plantado, agora são provedoras, no mínimo, da subsistência destas famílias. É comum encontrar nas propriedades mais pobres hortas, pomares, criações (peixes, aves, vacas, porcos), diversificação e consórcio de culturas etc... 
Pelas declarações de alguns dos jovens foi possível perceber o aproveitamento do que se aprende no programa e suas conseqüências. Um dos jovens entrevistados contou:

“O manejo feito pelo meu pai na lavoura de café era realizado na hora errada, além disso, ele gastava muito com adubo. Conversei com o monitor e alguns produtores, $e$ então, passamos a utilizar adubação verde e orgânica e a fazer o manejo na hora certa. A produção dessa safra já foi maior que a outra".

Um outro jovem contou como percebeu que sua propriedade poderia produzir uma atividade que nunca tinha imaginado:

"Fui numa visita num pesque-e-pague e descobri que dava para criar peixe na minha propriedade. Fiz algumas pesquisas e, então, eu e meu irmão abrimos dois tanques puxando água de um córrego que passa dentro do meu sítio e estamos tratando dos peixes com os restos dos porcos. Só gastei com a compra dos alevinos".

Estes fatos demonstram que alguns dos ensinamentos propostos pelo PROJOVEM não necessitam de grandes investimentos e são facilmente absorvidos pelas famílias desprovidas de recursos. Uma mãe que possui dois filhos no PROJOVEM declarou: "quem tem terra e passa fome é porque não gosta de trabalhar". Apesar das soluções simples encontradas por alguns jovens para melhorar as condições da família, muitos ainda afirmaram que a falta de recursos financeiros é o grande empecilho para praticarem o que aprendem no programa.

Outra modificação facilmente visualizada está relacionada ao comportamento dos jovens, e essa mudança, sem dúvida, se deve ao programa. $O$ estilo das aulas, mesmo 
não sendo totalmente construtivistas, estimula os jovens a buscar respostas às suas dúvidas, forçando-os a deixar de lado a timidez e a aperfeiçoar seus conhecimentos por meio de leituras e trocas de experiências.

O PROJOVEM é visto por muitos jovens como uma chance de vida melhor. Alguns não medem esforços para participar do programa, afastam-se das famílias, percorrem longas distâncias entre suas casas e o núcleo e pagam transporte. Os jovens entrevistados da zona rural de Miracatú (município próximo de Peruíbe) que freqüentam o núcleo de Peruibe chegam a levar quatro horas entre suas casas e o núcleo. As famílias destes jovens, no momento da entrevista, atravessavam sérias dificuldades financeiras. Talvez por isso, durante a entrevista, estes jovens demonstraram dedicação ao programa, disciplina, senso de cooperativismo (são propensos ao trabalho em equipe), interesse em aprender e crença que o PROJOVEM poderá melhorar suas condições de vida. Nas palavras de um dos jovens entrevistados: "A única coisa que pode nos ajudar a encaminhar nosso futuro vai ser a realização deste projeto".

Assim como os jovens de Miracatú, a maior parte dos jovens que freqüentam o PROJOVEM vê no programa uma alternativa de vida melhor, mas que depende do esforço próprio de cada um deles. Entretanto, existem jovens descomprometidos com essa idéia, muitos querem melhorar de vida, mas de preferência sem muitas dificuldades ou longe do campo. Dos núcleos que compõem este estudo, Peruíbe e Maracaí foram os que mais demonstraram evidências que muitos dos seus jovens só esperam uma oportunidade para abandonar o campo.

Peruibe expõe a contradição de apresentar jovens extremamente interessados e outros não, que acabam atrapalhando o andamento das atividades do núcleo. Por ser uma cidade que depende economicamente do turismo, alguns dos jovens entrevistados trabalham como garçons e guias durante a temporada, época em que mais ganham dinheiro. Estes jovens possuem características urbanas muito fortes: usam brincos, 
tingem o cabelo e falam muitas gírias. No restante do ano trabalham em suas propriedades ou na de vizinhos. Mas na linguagem de um deles "sempre sobra tempo para pegar umas ondas e conhecer umas minas". São jovens urbanizados que dificilmente permanecerão no campo.

No núcleo de Maracaí, apesar de a grande maioria dos jovens participar ativamente das atividades do programa, muitos deles demonstraram interesse em continuar seus estudos à nível superior. Entretanto, as profissões preferidas pelos jovens não estão relacionadas ao meio rural. É pouco provável que eles continuem no campo.

Os fatos narrados acima podem ter sido gerados por uma mobilização mal feita das famílias. No caso de Peruíbe, apurou-se que a mobilização foi feita por pessoas que não sabiam o significado real do programa, inclusive um italiano e um argentino. Foram prometidos diversos cursos (mecânica, carpintaria e costura) para atrair os jovens. Muitos jovens entraram para o PROJOVEM e logo o abandonaram. Entretanto, a imagem distorcida dos objetivos do programa, passada pelos primeiros mobilizadores, ainda persiste e leva muitos jovens a procurá-lo.

Em Maracaí, a identificação de jovens com as características necessárias para participar do programa não foi totalmente conseguida. A maior parte dos jovens é constituída por filhos de pequenos produtores rurais, mas, na maioria, não são carentes de recursos físicos, financeiros ou humanos; muitos deles residem nas cidades e também existem alguns que não possuem terra para desenvolver seus projetos. Estes fatos não impedem a participação de um jovem no programa, mas sinalizam que o futuro deles pode não estar relacionado ao campo. Um dos jovens de Maracaí declarou gostar de participar do programa, mas pretende estudar medicina, quando isso acontecer seu projeto será assumido pelo pai ou abandonado. Apesar de muitos jovens estarem realmente interessados no programa, muitos pretender simplesmente aprender algo mais. A má mobilização conduz ao desperdício de recursos financeiros e humanos em jovens que dificilmente utilizarão as técnicas aprendidas no programa. $\mathrm{Na}$ opinião de um dos 
monitores, "a lição de vida vai servir para todos, mas este investimento poderia estar sendo feito em jovens que realmente precisam e estão interessados em melhorar suas vidas no campo".

Os monitores possuem formação técnica adequada aos fins do programa, mas não possuem uma formação pedagógica suficiente para isso. Este fato demonstra incoerência entre o sistema de ensino proposto pelo PROJOVEM e a formação dos monitores. Todos eles demonstraram muitas preocupações em relação à aplicação do construtivismo, apesar de todos saberem, na teoria, "o que é construtivismo" e "como ser construtivista". Pelas entrevistas e observações, ficou claro que todos se esforçam para serem construtivistas (as aulas do PROJOVEM fogem do padrão tradicional de ensino, mas acabam caindo no mesmo princípio, pois suas atividades não provocam nos jovens o ato da reflexão e assimilação). Este esforço conduz a um paradoxo, muitos acreditam que estão sendo construtivistas, mas pelo observado, nenhum conseguiu. No acompanhamento das aulas e pelas entrevistas, só foi visto e ouvido repetições do que é feito nos cursos de capacitação de monitores. Os monitores utilizam-se do trabalho realizado nestes encontros para "bolar" suas atividades, o que caracteriza incompreensão e falta de criatividade. Os monitores não conseguem avançar sozinhos no conteúdo do programa dentro da linha construtivista. Esta limitação pode ter sido gerada pelo tipo de ensinamento que os monitores receberam nos cursos tradicionais, o que torna mais fácil para eles agirem como transferidores de informações e não como orientadores do processo de aprendizagem dos jovens. Outra característica que falta a alguns monitores é a experiência em empreendimentos rurais. Os monitores têm o conhecimento, mas não têm a atitude empresarial.

Outro problema pedagógico percebido pelo contato com os monitores é a utilização do projeto como eixo de aprendizagem somente sob o aspecto técnico-administrativo. Este fato ficou claro pelas intensas reclamações dos monitores sobre a deficiência educacional apresentada por alguns jovens. Os monitores parecem desconhecer que a única exigência educacional para se freqüentar o PROJOVEM é que o jovem saiba ler, 
escrever e as operações matemáticas básicas. As outras necessidades deveriam ser preenchidas pelo próprio programa por meio da utilização do projeto como eixo de aprendizagem como um todo, amenizando essas deficiências.

Além do construtivismo, outro motivo de insegurança que atinge os monitores é o seu contrato de trabalho. Os monitores em final de contrato não agem com o mesmo ideal e determinação de outros períodos. Esse descontentamento é sentido dentro do núcleo, tanto pelos jovens quanto pelos outros colegas de trabalho. A participação do monitor em final de contrato é decrescente, pois suas preocupações e incertezas em relação ao futuro aumentam, sobrecarregando o trabalho dos outros monitores. Além disso, existe outro inconveniente. $\mathrm{O}$ monitor afastado é um monitor treinado, envolvido com o programa e que conhece individualmente cada jovem. No final do contrato, este monitor muitas vezes é substituído por outro sem experiência. Na linguagem dos monitores, “este novo monitor pega o bonde andando, interrompendo a continuidade dos trabalhos". O depoimento de um monitor que foi dispensado e recontratado mostra isso claramente:

“Estou no PROJOVEM não por causa de salário, mas sim de um ideal. É fantástico presenciar a mudança destes meninos. $O$ término do meu contrato foi angustiante. É preciso encontrar um mecanismo para proteger aqueles monitores que queiram participar realmente do PROJOVEM. Na dispensa de um monitor, não é só o gasto que deve ser considerado, mas também a perda de conhecimento. Nós não devíamos ser somente cobrados, deviamos ser mais valorizados. O entra e sai de monitores impede o programa de encontrar sua identidade...não é tão simples substituir o monitor quanto se pensa”. 
Alguns monitores ainda resistem em aceitar sua condição secundária frente à Associação de Pais, manipulando as decisões das Associações mais fracas e impondo vantagens e benefícios a seu favor. No depoimento de alguns pais surgiram evidências disso: monitores de alguns núcleos que conduzem reuniões da Associação, monitores cumprindo funções da Associação e pais que acham que devem fazer o que os monitores aconselham, pois eles têm estudo e sabem mais do que eles. Entretanto, este tipo de mentalidade está mudando. Em Maracaí, a evolução da Associação de Pais é percebida pelas reclamações dos monitores. Para os monitores, a Associação, como dona do PROJOVEM, pressiona e ameaça muito os monitores, tirando-lhes a liberdade de agir e solucionar alguns problemas rapidamente.

Em Peruibe, a situação é um pouco mais complicada, com a Associação assumindo uma postura dominadora sobre os monitores. A Associação age como um patrão que manda e desmanda sem ouvir as sugestões dos monitores. Ela decide e eles cumprem. No momento da entrevista, praticamente não existia diálogo entre Associação e monitores. A presidente da Associação explicou que na gestão anterior os monitores possuíam grande influência e acabavam não cumprindo suas obrigações como deveriam ser feitas e, agora, ela está corrigindo estes vícios. Em Rancharia foi possível perceber uma grande admiração dos pais pelos monitores, chegando a sugerir até uma relação de dependência por parte dos pais.

Um outro problema citado pelos monitores entrevistados é o isolamento dos núcleos frente à Assessoria da ACP. Na opinião dos monitores, a Assessoria teria que ser mais atuante e presente nos núcleos para poder corrigir o que não está correto no trabalho deles. A única oportunidade para os monitores exporem problemas e angústias acontece nos cursos de capacitação realizados a cada três meses. Para eles, este momento é insuficiente e, na maioria das vezes, retornam destes encontros sem a solução desejada. Os monitores consideram que os problemas são tratados de maneira muito geral, descaracterizando o problema individual de cada núcleo ou monitor. $\mathrm{Na}$ opinião de um dos monitores: 
"Ajudaria se a Assessoria pudesse visitar mais os núcleos. Talvez eles pudessem enxergar melhor as falhas; com eles aqui teriamos mais intimidade e poderíamos expressar melhor nossas dificuldades. Eles aproveitariam para conhecer a realidade das familias; cada núcleo tem uma realidade e uma necessidade".

A ausência de visitas de membros da Assessoria aos núcleos também é reclamada por alguns pais. Alguns pais acreditam que o contato da Assessoria da ACP com os jovens é muito importante para aumentar a confiança deles no programa e para estimulá-los a prosseguir com seus projetos. Segundo uma das mães entrevistadas, quando alguém da Assessoria visita o núcleo os jovens ficam muito mais animados para realizarem seus projetos.

Apesar dos problemas, o PROJOVEM é uma inovação em termos de programas de educação profissional voltados ao meio rural, pois por meio da união da pedagogia de alternância à elaboração e implementação do projeto de investimento, o PROJOVEM atende a uma importante preocupação social e educacional que é a criação de emprego para os egressos do meio rural carente. Por ser um projeto em fase de implantação e diferenciado em práticas educacionais, é necessário uma ampliação do suporte pedagógico oferecido aos monitores e um acompanhamento dos trabalhos de núcleos.

\subsection{Resultados do cálculo da TIR}

O método para se calcular a taxa interna de retorno consistiu em combinar os custos da educação assumidos pelo CEETEPS e pais (Tabela 6.3) e alguns diferenciais de renda resultantes da aquisição de educação diferenciada oferecida pelo PROJOVEM. O cálculo foi feito considerando um período de vida útil para o trabalhador dos 16 aos 60 anos de idade, sendo que durante os três primeiros anos só foram computadas as despesas envolvidas na educação dos jovens que cursaram o PROJOVEM, apesar de 
eles estarem, efetivamente, trabalhando no planejamento e implantação de uma atividade empresarial (típico "on the job trainning").

Tabela 6.3: Gasto total por jovem nos 4 núcleos pesquisados do PROJOVEM durante o ano de 1998.

\begin{tabular}{lc}
\hline item & Total ano/jovem \\
\hline monitores & $1.684,54$ \\
cozinheiros & 297,50 \\
quilometragem & 157,50 \\
treinamento & 83,04 \\
manutenção & 70,00 \\
alimentação & 85,79 \\
depreciação & 116,67 \\
\hline Total ano/jovem & $2.495,04$ \\
\hline
\end{tabular}

Fonte: CEETEPS (1998) e dados da pesquisa (1999).

Ao valor total de gastos anuais por jovem falta acrescentar o custo de oportunidade, ou seja, a perda de rendimentos provocada pelo jovem ter deixado de trabalhar uma semana por mês para freqüentar o PROJOVEM durante os 3 anos do programa. Considerando o jovem que freqüenta o programa como trabalhador rural, seu custo de oportunidade seria de $\mathrm{R} \$ 600,00 / \mathrm{aa}$.

Primeiramente, a TIR foi calculada considerando para os jovens do PROJOVEM o rendimento do projeto de investimento e para os jovens que não cursaram o PROJOVEM o rendimento de um trabalhador rural na agricultura paulista, respectivamente $R \$ 3.504,00 /$ ano e $R \$ 2.400,00 / a n o$, como descrito no item 5.6 .1 do capítulo 5. A taxa interna de retorno encontrada foi de $10,56 \%$.

Em seguida, a TIR foi calculada assumindo para os jovens do PROJOVEM o rendimento do projeto e para os jovens que não cursaram o PROJOVEM, o salário alternativo fora da agricultura (servente de obras), respectivamente $\mathrm{R} \$ 3.504,00 /$ ano e $\mathrm{R} \$ 2.908,82 /$ ano. A taxa interna de retorno, neste caso, foi de $4,41 \%$. 
Os resultados encontrados para os retornos à educação oferecida pelo PROJOVEM vêm confirmar os resultados obtidos em trabalhos anteriores, evidenciando a rentabilidade positiva dos investimentos em educação. Kassouf (1997), com dados da Pesquisa Nacional sobre Saúde e Nutrição, em 1989, encontrou para o meio rural de todo o Brasil uma taxa de retorno de $11,60 \%$ para homens e $13,60 \%$ para mulheres. Loocked et al. (1980) encontrou para países da África, América Latina e Europa, uma taxa de 7,4\% de aumento na produtividade agrícola a cada 4 anos de educação formal. Já com dados de regiões urbanas, Leal \& Werlang (1991) encontraram uma taxa de retorno à educação em torno de $16 \%$ ao ano para o período de 1976-89.

Os resultados da TIR mostram que o PROJOVEM traz beneficios nos dois casos comparados, ou seja, proporciona um retorno maior aos jovens que o cursaram. Entretanto, a taxa interna de retorno é maior quando se compara jovens que cursaram o PROJOVEM e aqueles que não cursaram, mas permaneceram no campo como trabalhadores rurais. A diferença de rendimento entre estes jovens mostrou-se bastante significativa, indicando que a educação técnica oferecida pelo PROJOVEM é uma boa possibilidade de aumento nos rendimentos para aqueles que pretendem continuar trabalhando no meio rural.

Observando as possibilidades de rendimento de um jovem que não cursou o PROJOVEM no campo e na cidade percebe-se que os rendimentos urbanos são maiores, o que pode contribuir para incentivar os jovens rurais a abandonar o campo. Portanto, quando um jovem não tem acesso a um programa como o PROJOVEM, que possa significar uma alternativa de vida melhor no campo, ele é mais facilmente atraído para as cidades em busca de maiores ganhos e melhoria da qualidade de vida. Quando se considera um jovem que participa do PROJOVEM, as expectativas de ganhos são maiores tanto no campo quanto na cidade, o que pode influenciar sua decisão de permanecer no seu meio de origem. 
O retorno positivo proporcionado aos jovens que cursam o PROJOVEM tem um amplo significado, pois transcende o indivíduo e beneficia a sociedade como um todo. Este efeito é conhecido como externalidade positiva da educação. Com efeito, a possibilidade de ganhos maiores para os jovens no campo pode contribuir para a fixação dos jovens e suas famílias no campo. Além disso, este jovem terá aumentada sua capacidade de consumo, terá possibilidade de empregar outras pessoas (dependendo do sucesso de sua atividade), poderá se tornar um emissor de conhecimento, terá aumentada sua capacidade de entender e resolver problemas técnicos, sociais e econômicos, bem como, pelo maior acesso à informação, de desfrutar de melhores condições de saúde e higiene.

Em relação aos custos, o cálculo revelou que a maior parte dos custos do PROJOVEM é paga pelo parceiro CEETEPS. Os gastos do CEETEPS correspondem a, aproximadamente, $90 \%$ do custo total do programa. O restante dos gastos são assumidos pelos pais e eventuais parceiros, tal como as prefeituras.

O CEETEPS, preocupado em levar conhecimento técnico a todas as áreas da economia, possui cursos voltados para o meio rural. Entre eles está o curso de técnico agrícola. São 35 escolas agrotécnicas no Estado de São Paulo dedicadas a formar mão-de-obra especializada para o setor. Entretanto, o público atendido por essas escolas é muito diferente do PROJOVEM. Como constatado em alguns trabalhos discutidos anteriormente, a grande maioria dos jovens que cursam estas escolas é proveniente do setor urbano e aspira por ocupações urbanas de prestígio depois de formados, como gerentes, advogados, médicos etc.. O PROJOVEM surgiu ao CEETEPS como alternativa para alcançar uma fatia da população rural que possui dificuldades em prosseguir seus estudos para conseguir alcançar o nivel técnico.

Os gastos do CEETEPS na manutenção das suas 35 escolas agrotécnicas estão resumidos na Tabela 6.4. Traçando uma comparação dos valores por aluno com os gastos do CEETEPS por jovem com os 4 núcleos pesquisados neste trabalho, pode-se 
observar que o custo total ano/aluno das escolas agrícolas é um pouco mais alto que o encontrado para os 4 núcleos pesquisados do PROJOVEM (Tabela 6.3). Essa diferença poderia ser ainda maior se o custo calculado para o PROJOVEM não incluísse os gastos com a depreciação dos imóveis e alimentação. Além disso, deve-se considerar que o PROJOVEM tem um enorme potencial de redução do custo/jovem, pois está apenas iniciando, com muitos núcleos possuindo ainda apenas uma turma. Entretanto, a possibilidade de abertura de novas turmas e de novos núcleos é muito grande. Como dito anteriormente, o setor rural tem uma grande quantidade de jovens que se encaixa no perfil desejado pelo programa. Portanto, existe perspectiva de aumento da demanda pelo PROJOVEM, ocasionando diminuição dos custos necessários para a continuidade do programa.

Tabela 6.4: Gasto total por aluno das 35 escolas agrotécnicas mantidas pelo CEETEPS no ano de 1997.

\begin{tabular}{lll} 
item & Gasto total (R\$) & $\begin{array}{l}\text { Total de gastos } \\
\text { ano/aluno (R\$) }\end{array}$ \\
\hline Pessoal e encargos sociais & $13.426 .455,36$ & $2.213,76$ \\
Estagiários & $2.127,60$ & 0,35 \\
Energia elétrica & $345.937,91$ & 57,03 \\
Água e esgoto & $562.936,08$ & 92,81 \\
Telefone & $24.740,14$ & 4,08 \\
Outras taxas & $5.687,20$ & 0,93 \\
Material de consumo & $1.598 .308,28$ & 263,53 \\
Serviços de terceiros & $359.090,38$ & 59,20 \\
Material permanente & $15.469,75$ & 2,55 \\
\hline Total & $16.340 .752,70$ & $2.694,27$ \\
\hline Fonte: CEETEPS, 1997.
\end{tabular}

Os resultados sobre o desempenho econômico do programa mostram que o investimento em educação é dos mais rentáveis, tanto do ponto de vista econômico quanto social. Numa economia que busca reduzir as disparidades nos rendimentos dos trabalhadores, é necessário o conhecimento da distribuição de renda e do nível de escolaridade para orientar a alocação ótima dos recursos públicos na educação. 
"It's all chance, but we can't stop now"

N.S

\section{7 - CONCLUSÕES}

Este estudo teve como objetivo determinar as vantagens econômicas e sociais advindas da implantação do Programa de Formação de Jovens Empresários Rurais. Trata-se de um programa diferenciado tanto pela metodologia de ensino, quanto pela população a quem se dedica: jovens carentes do meio rural.

Os resultados comprovaram que o PROJOVEM está atendendo às populações mais necessitadas do meio rural. A grande maioria dos jovens é formada por filhos de pequenos produtores rurais, com pouco estudo formal, carentes de recursos físicos e financeiros, empregadores de poucas técnicas produtivas e detentores de poucos conhecimentos de gestão administrativa (essencial para a sobrevivência num "mundo" competitivo).

Apesar de ser um projeto ainda em construção, o PROJOVEM está modificando a vida das famílias que $o$ compõem. São mudanças técnicas, administrativas e comportamentais. Entretanto, a maior vantagem de se cursar o programa está associada ao mercado de trabalho, pois espera-se que todos os jovens, ao término do programa, tenham seu próprio trabalho (negócio). A maioria dos jovens acredita que a realização do projeto de investimento pode melhorar sua vida. Eles conhecem as etapas de realização do projeto, o significado do termo empresário rural, têm suas próprias opiniões sobre algumas técnicas aprendidas e pretendem continuar vivendo e trabalhando no meio rural. Os primeiros projetos em fase de conclusão demonstram que os jovens absorveram os ensinamentos e as informações transmitidas pelo programa, reconhecendo a importância do planejamento de atividades e da busca por novas alternativas. 
As mudanças sentidas pelas famílias fazem-nas acreditar que o PROJOVEM representa uma chance de vida melhor. Para isso, cada uma das partes envolvidas (jovens, pais e monitores) tem cumprido sua parte. Entretanto, muito ainda tem que ser melhorado: mobilização correta dos jovens e famílias; seleção de monitores comprometidos com as idéias do programa; participação dos pais; supervisão das atividades de núcleo, etc...

O trabalho dos monitores não está de acordo com o que era esperado deles por parte dos idealizadores do programa. Os monitores têm formação técnica necessária para o trabalho, mas alguns não têm vivência empresarial, estão ensinando aos jovens aquilo que eles mesmos não sabem o que é. Outra falha percebida está na dificuldade de aplicação do construtivismo. Mesmo assim, os monitores conseguem despertar algum interesse do jovem, pois o assunto tratado nas sessões de núcleo normalmente está ligado ao seu dia-a-dia.

Quanto às questões levantadas durante o estudo bibliográfico, pode-se concluir que:

1. Os jovens diferenciam o ensino promovido pelo PROJOVEM do ensino obtido nas escolas tradicionais;

2. O PROJOVEM estimula a troca de informações entre pais e filhos, apesar de constatar que alguns pais são relativamente resistentes à introdução de novas técnicas;

3. O PROJOVEM, assim como outras escolas e programas, oferece educação técnica por meio de Alternância. Entretanto, o PROJOVEM deverá dispor de um fundo rotativo que permitirá aos jovens pôr em prática aquilo que aprendem no programa;

4. Aproximadamente metade dos pais, apesar de desempenhar funções empresariais dentro de sua propriedade, recusa o termo "empresário rural" para caracterizar seu trabalho. Para eles, a palavra empresário está relacionada à posse de muito dinheiro; 
5. A amostra pesquisada mostrou que a escolaridade dos pais praticamente não interfere no nível de escolaridade dos filhos. Os pais estudaram muito menos do que seus filhos estão tendo oportunidade de estudar;

6. O coeficiente de correlação (Spearman) mostrou que, apesar de existir uma fraca associação positiva entre as variáveis "tempo de permanência dos pais no meio rural e nível de renda das famílias" na amostra, este resultado não pode ser estendido para toda a população estudada;

7. O resultado do teste de Spearman mostrou que é possível generalizar para toda a população que pais com maior nível de escolaridade obtêm os maiores níveis de rendimento;

8. O tipo de educação oferecida pelo PROJOVEM, por dar oportunidade ao jovem rural de melhorar seu padrão de vida no campo, tende a fixá-lo no seu meio de origem;

9. A demanda pelo programa é maior entre os filhos de proprietários de terra;

10. Os pais acompanham a educação dos filhos, mas às vezes não querem assumir responsabilidades; estão acostumados a esperar que a ajuda "caia do céu";

11. Os monitores recebem capacitação suficiente para cumprir sua função de facilitador de aprendizagem, mas não evoluem além do que registraram durante os encontros de treinamento. É preciso salientar que a compreensão e a assimilação do processo de aprendizagem construtivista são lentas e isso exigiria um acompanhamento contínuo e aprofundado de suas atividades.

De uma maneira geral, a conclusão que se pode inferir deste trabalho é que investimento em educação profissional no meio rural apresenta resultados econômicos e sociais bastante positivos. Este estudo mostrou que o PROJOVEM oferece possibilidades de jovens sem muitos capitais (físicos, financeiros e humanos) virem a ter uma qualidade 
de vida no campo superior à de jovens rurais que não freqüentaram o programa ou foram para a cidade em busca de trabalhos não qualificados, como serventes na construção civil. A partir do momento em que o programa possibilita rendimentos maiores no campo que na cidade, o setor urbano deixa de ser tão atrativo para o jovem rural. Deste modo, investimentos em educação, além de propiciar retorno econômico positivo, são desejáveis do ponto de vista social.

A Teoria do Capital Humano considera o ser humano como o recurso mais importante de uma nação. O desenvolvimento máximo dos recursos humanos representa a oportunidade de se investir num recurso que é capaz de, no longo prazo, contribuir para uma vida produtiva e útil para todos. Para o trabalhador rural, a educação profissional ajuda na combinação e alocação mais eficiente dos fatores de produção, evitando que ele desperdice tempo e dinheiro na aplicação de técnicas que não se adequam às suas necessidades. A educação voltada para o trabalho não constitui a única solução para os problemas socioeconômicos enfrentados pelos paises em desenvolvimento. Entretanto, ameniza os ciclos trágicos provocados pelas crises econômicas, desemprego, automação, etc...

Em relação ao custo médio por aluno, o PROJOVEM mostrou-se uma opção de investimento pelo menos tão viável quanto as escolas agrícolas mantidas pelo CEETEPS.

Este trabalho é, em suma, o retrato do que o PROJOVEM é capaz e suas potencialidades. No entanto, ainda há muito o que melhorar na educação das populações rurais carentes. Espera-se que as informações aqui apresentadas possam contribuir para o entendimento da realidade enfrentada pelas famílias atendidas pelo PROJOVEM. Fica a conviçãa de que o programa é um importante instrumento de fortalecimento da agricultura familiar e, se bem conduzido, um fator de desenvolvimento das regiões mais carentes, gerando renda, emprego e bem-estar social. 


\section{REFERÊNCIAS BIBLIOGRÁFICAS}

ABRAMOVAY, R.; CAMARANO, A.A. Êxodo rural, envelhecimento e masculinização no Brasil: panorama dos últimos 50 anos. Texto para Discussão IPEA, n.621, jan. 1999. 28p.

ADANT, F. Formação dos pequenos e médios produtores para a gerência de empresas agrícolas. Brasília: EMBRATER, 1987. 26p.

ALVES, R.C.P. Análise de uma escola família agrícola como proposta pedagógica para o meio rural. Viçosa, 1994. 102p. Dissertação (MS) - Universidade Federal de Viçosa.

ALVES FILHO, E. Fatores associados às aspirações educacionais e ocupacionais das escolas agrícolas de $2^{\circ}$ grau. Piracicaba, 1977. 91p. Dissertação (MS) - Escola Superior de Agricultura Luiz de Queiroz, Universidade de São Paulo.

ARAÚJO, J.L.; BRESSAN, M. Caracterização sócio-econônica dos parceleiros do Projeto de Irrigação de Bebedouro, Petrolina, PE. Boletim de Pesquisa, n.46, 1992.

BARROS, R.P.; MENDONÇA, R.S.P. Os determinantes da desigualdade no Brasil. Texto para Discussão - IPEA, n.377, jul.1995. 60p.

Investimentos em educação e desenvolvimento econômico. Texto para Discussão - IPEA, n.525, nov.1997. 8p.

BASTOS, E.; DIJIERKMAN, D. Diferenciação social e efeitos de uma reforma agrária. Ensaios de Economia - UFPE, n.7, p.443-458, 1997.

BECKER, G.S. Human Capital: a theorical and empirical analysis with special reference to education. 3.ed. Chicago: The University of Chicago Press, 1993. 390 . 
BOWMAN, M.J. On Theodore W. Schultz's contribuitions to economics. The Scandinavian Journal of Economics, v. 82, n. 1, p.80-107, 1980.

BURKE, T.J. PROJOVEM: Relatório de avaliação. Piracicaba, 1998. 12 p. (Parecer técnico apresentado ao Projeto UNIR/ESALQ e CEETEPS).

CAMPOS, A.C. Escolaridade e suas implicações no mercado de trabalho rural no Estado do Paraná, 1970 e 1980. Piracicaba, 1998. 197p. Dissertação (MS) - Escola Superior de Agricultura Luiz de Queiroz, Universidade de São Paulo.

CHANDLER, A.D. What is a firm? A historical perspective. European Economic Review, n.36,_1992.

COGO, L.C. Estudo preliminar da viabilização sócio-econômica e ambiental das casas familiares rurais de Barracão e Santo Antônio do Sudoeste. Santo Antônio do Sudoeste, 1994. 96p. Monografia (Especialização) - Universidade Estadual do Centro-Oeste.

FUNDAÇÃO INSTITUTO BRASILEIRO DE GEOGRAFIA E ESTATÍSTICA. Censo demográfico, 1991. http://www.ibge.gov.br/ (02/11/99).

FUNDAÇÃO INSTITUTO BRASILEIRO DE GEOGRAFIA E ESTATÍSTICA. Censo Agropecuário, 1996. http://www.ibge.gov.br/ (02/11/99).

FUNDAÇÃO INSTITUTO BRASILEIRO DE GEOGRAFIA E ESTATÍSTICA. Pesquisa mensal de emprego, out. 1998-set. 1999. http:/www.ibge.gov.br/ $(03 / 11 / 99)$.

FUNDAÇÃO INSTITUTO BRASILEIRO DE GEOGRAFIA E ESTATÍSTICA. Pesquisa anual da indústria da construção civil, out. 1998-set. 1999. http://www.ibge.gov.br/ (03/11/99). 
GISSER, M. Schooling and the farm problem. Econometrica, v.29, n.3, p.582-592, July 1965.

GRILLO, A. A terra tolhida, Escola Rural em área de produção familiar. Ribeirão Preto, 1978. 196p. Dissertação (MS) - Faculdade de Filosofia Ciências e Letras "Barão de Mauá".

GROSSI, M.S. Fatores de educação e status ocupacional associados à renda do pequeno produtor. Viçosa, 1978. 83p. Dissertação (MS) - Universidade Federal de Viçosa.

HARBISON, F.; MYERS, C.A. Educação, mão-de-obra e crescimento econômico: estratégia do desenvolvimento dos recursos humanos. Rio de Janeiro: Fundo de Cultura, 1965. 258p.

HOFFMANN, R.; Engler, J.J.; Neves, E.M. et al. Administração da empresa agrícola. 6.ed. São Paulo: Pioneira, 1989. 325p.

HOFFMANN, R. Ricos e pobres na agricultura brasileira em 1995 (compact disc). IN: CONGRESSO BRASILEIRO DE ECONOMIA E SOCIOLOGIA RURAL, 35, Natal, 1997. Brasília: SOBER, 1997.

ILHA, A.S.; LIMA, J.E. Impactos da educação na pequena produção agrícola em Minas Gerais. Pesquisa e Planejamento Econômico, v.19, n.1, p.183-202, abr. 1989.

KASSOUF, A.L. Retornos à educação e treinamento nos setores urbano e rural no Brasil. In: CONGRESSO BRASILEIRO DE ECONOMIA E SOCIOLOGIA RURAL, n.34, Aracajú, 1996. Anais. Brasília: SOBER, 1996. v.1, p.771-778.

LEAL, C.I.S.; WERLANG, S.R.C. Retornos em educação no Brasil: 1976-1989. Pesquisa e Planejamento Econômico, v. 21, n. 3, p. 559-574, dez. 1991.

LEVIN, J. Estatística aplicada a ciências sociais. 2.ed. São_Paulo: Harbra, 1987. 392p. 
LOCKHEED, M.E.; JAMISON, D.T.; LAU, L.J. Farm education and farm efficiency: a survey. Economic Development and Cultural Change, v.29, n.1, p.37-76, Oct.1980.

MARCONI, I.; LAKATOS, E.M. Técnicas de pesquisa: planejamento e execução de pesquisas, amostragens e técnicas de pesquisa, elaboração, análise e interpretação de dados. 2.ed. São Paulo: Atlas, 1990. 231p.

MENGA, L.; André, M.E.D.A. Pesquisas em educação: abordagens qualitativas. São Paulo: Pedagógica e Universitária, 1986. 98p.

MINCER, J. Schooling, experience and earnings. New York: Columbia University Press, 1974. 152p.

NISKIER, A. A brasilização da miséria e o papel da educação. Carta Mensal, v.38, n. 450, p.45-49, set. 1992.

NUNES, H.T. Administração de recursos humanos e produtividade dos trabalhadores em empresas agrícolas: um estudo de caso. Piracicaba, 1995. 104p. Dissertação (MS) - Escola Superior de Agricultura Luiz de Queiroz, Universidade de São Paulo.

PERES, F.C.; GATTI, M.I.; DELFINE, S.T. et al. PROJOVEM: a experiência do Programa de Formação de Jovens Empresários Rurais. Piracicaba: USP /ESALQ/ DIBD /EXAGRI, 1998. 138p.

PERES, F. C. Alguns condicionantes do desenvolvimento da agricultura brasileira. Preços Agrícolas. v.11, n. 128, p.9-14, jun. 1997.

PRASERES, Y.J.P. Os programas de capacitação de mão-de-obra agrícola no estado do Maranhão. Piracicaba, 1976. 96p. Dissertação (MS). Escola Superior de Agricultura Luiz de Queiroz - Universidade de São Paulo. 
SCHULTZ, T. W. O Capital Humano: investimento em educação e pesquisa. Rio de Janeiro: Zahar, 1973. 250p.

SMITH, A. Investigação sobre a natureza e as causas da riqueza das nações. São Paulo: Abril Cultural, 1974. 247p.

SOLOW, R. M. Technical change and the aggregate production function. The review of economics and statistics, v.39, n.3, p. 312-320, 1957.

TOMPKIN, J. R. Estatística e métodos de pesquisa em ciências sociais rurais. Piracicaba: ESALQ.Departamento de Economia, Administração e Sociologia, 1967. 96p. (Série Didática, 7).

ZIMMERMANN, I. Educação e modernização da produção: algumas considerações. Indicadores Econômicos, v.22,n.4, p. 293-308, jan. 1995.

WELCH, F. Education in production. Journal of Political Economy, v.78, n.1, p.3539, Jan./Fev. 1970.

WERTHEIN, J.; BORDENAVE J. D.(org.) Educação Rural no Terceiro Mundo: Experiências e Novas Alternativas. Rio de Janeiro: Paz e Terra, 1981. 370p. 


\section{APÊNDICES}




\section{Apêndice 1}

Gastos do CEETEPS com as Escolas Agrícolas, 1998

\begin{tabular}{|c|c|c|c|c|c|c|}
\hline Município & $\begin{array}{l}\text { Alunos } \\
\text { em } \\
1997\end{array}$ & $\begin{array}{l}\text { Pessoal e } \\
\text { encargos } \\
\text { sociais (R\$) }\end{array}$ & $\begin{array}{l}\text { Estagiários } \\
\text { (R\$) }\end{array}$ & $\begin{array}{l}\text { Energia } \\
\text { elétrica (R\$) }\end{array}$ & $\begin{array}{l}\text { Água e } \\
\text { esgoto } \\
\text { (R\$) }\end{array}$ & $\begin{array}{l}\text { Telefone } \\
\text { (RS) }\end{array}$ \\
\hline Andradina & 68 & $230.606,78$ & & $3.455,01$ & & \\
\hline $\begin{array}{l}\text { Pres. } \\
\text { Prudente }\end{array}$ & 353 & $574.549,70$ & & $17.170,86$ & & 455,86 \\
\hline Igarapava & 176 & $295.208,92$ & & $8.909,14$ & & 302,41 \\
\hline Votuporanga & 182 & $331.201,44$ & & $9.573,04$ & $1.862,24$ & 453,17 \\
\hline Cabrália Pta. & 69 & $267.967,78$ & & $6.725,92$ & & 603,64 \\
\hline $\begin{array}{l}\text { Paraguaçu } \\
\text { Pta }\end{array}$ & 202 & $447.117,25$ & & $7.737,40$ & $4.934,30$ & 559,98 \\
\hline Jundiaí & 246 & $43 \cdot 3.236,95$ & & $19.200,52$ & $\begin{array}{l}111.635,0 \\
6\end{array}$ & 424,31 . \\
\hline Franca & 190 & $409.774,94$ & & $10.809,61$ & $9.761,32$ & $4.546,73$ \\
\hline $\begin{array}{l}\text { Espírito Sto. } \\
\text { Pinhal }\end{array}$ & 273 & $492.791,50$ & & $19.643,05$ & & 768,66 \\
\hline Jacareí & 221 & $379.450,60$ & & $25.955,14$ & $\begin{array}{l}139.620,9 \\
4\end{array}$ & 661,03 \\
\hline Taquarivaí & 164 & $331.507,22$ & & $6.589,75$ & $41.521,56$ & 245,86 \\
\hline Dracena & 70 & $282.270,30$ & & $5.912,20$ & & \\
\hline Itapetininga & 157 & $364.935,77$ & & $16.662,28$ & & $1.276,31$ \\
\hline São Simão & 248 & $341.792,21$ & & $5.466,66$ & & 807,66 \\
\hline Rancharia & 199 & $449.828,41$ & & $7.146,71$ & $1.128,24$ & 472,38 \\
\hline Cafelândia & 40 & $302.582,15$ & & $4.863,06$ & & 609,39 \\
\hline Adamantina & 202 & $430.141,86$ & & $9.616 ; 65$ & & 920,75 \\
\hline Penápolis & 220 & $450.610,21$ & & $13.291,10$ & & 656,00 \\
\hline $\begin{array}{l}\text { Rio das } \\
\text { Pedras }\end{array}$ & 183 & $364.535,58$ & & 11.782 .73 & & 738,06 \\
\hline $\begin{array}{l}\text { Cerqueira } \\
\text { César }\end{array}$ & 183 & $362.927,23$ & & $4.515,72$ & & \\
\hline Jales & 192 & $336.885,26$ & & $10.591,45$ & & 725,05 \\
\hline $\begin{array}{l}\text { Monte } \\
\text { Aprazível }\end{array}$ & 204 & $5.49 .862,62$ & & $14.21: 6,67$ & $41.634,90$ & $1.027,55$ \\
\hline Miguelópolis & 122 & $279.142,50$ & & $7.417,10$ & & $1.514,66$ \\
\hline Quatá & 157 & $406.787,52$ & & $5.357,52$ & $62.131,08$ & 368,61 \\
\hline $\begin{array}{l}\text { Cândido } \\
\text { Mota }\end{array}$ & 190 & $411.360,08$ & & $9.223,72$ & $49.852,10$ & 429,51 \\
\hline $\begin{array}{l}\text { Sta. Rita } \\
\text { Passa Quatro }\end{array}$ & 177 & $421.027,30$ & & $11.235,92$ & & 543,52 \\
\hline
\end{tabular}




\begin{tabular}{lllllll}
\hline Município & $\begin{array}{l}\text { Alunos } \\
\text { em } \\
\mathbf{1 9 9 7}\end{array}$ & $\begin{array}{l}\text { Pessoal e } \\
\text { encargos } \\
\text { sociais (RS) }\end{array}$ & $\begin{array}{l}\text { Estagiários } \\
(\mathbf{R S )}\end{array}$ & $\begin{array}{l}\text { Energia } \\
\text { elétrica (RS) }\end{array}$ & $\begin{array}{l}\text { Água e } \\
\text { esgoto } \\
\text { (RS) }\end{array}$ & Telefone (RS \\
\hline Sta. Cruz do & 184 & $443.854,32$ & & $7.171,78$ & & 531,90 \\
Rio Pardo & & & & & \\
Itu & 206 & $370.905,05$ & & $6.955,61$ & $82.659,84$ & 408,59 \\
Mirassol & 94 & $351.798,08$ & & $6.206,99$ & & 725,88 \\
Iguape & 85 & $341.817,97$ & & $3.406,77$ & $14.610,38$ & 658,90 \\
Jaú & 223 & $509.354,12$ & & $14.039,43$ & & 995,44 \\
Vera Cruz & 125 & $362.340,25$ & & $7.928,89$ & & 445,88 \\
Garça & 175 & $503.472,92$ & $2.127,60$ & $10.171,03$ & $1.263,64$ & 641,97 \\
Presidente & 156 & $223.111,46$ & & & 134,66 & 221,12 \\
Venceslau & & & & & & \\
São Manuel & 129 & $366.699,10$ & & $16.970,48$ & 185,82 & 999,36 \\
\hline Total & 6.065 & $13.426 .455,3$ & $769.545,95$ & $345.937,91$ & $562.936,0$ & $24.740,14$ \\
\hline
\end{tabular}

contin.

\begin{tabular}{llllll}
\hline Município & $\begin{array}{l}\text { Outras } \\
\text { taxas } \\
\text { (R\$) }\end{array}$ & $\begin{array}{l}\text { Material de } \\
\text { consumo } \\
\text { (R\$) }\end{array}$ & $\begin{array}{l}\text { Serviços de } \\
\text { terceiros (R\$) }\end{array}$ & $\begin{array}{l}\text { Material } \\
\text { permanente } \\
\text { (R\$) }\end{array}$ & $\begin{array}{l}\text { Total geral da } \\
\text { unidade (R\$) }\end{array}$ \\
\hline Andradina & $27.708,33$ & $5.319,63$ & & $272.089,75$ \\
Pres. Prudente & $5.467,44$ & $56.261,00$ & $9.527,00$ & & $663.431,86$ \\
Igarapava & & $44.338,50$ & $5.703,85$ & & $354.462,82$ \\
Votuporanga & $29.119,14$ & $9.566,82$ & & $381.775,85$ \\
Cabrália Pta. & $25.571,41$ & $4.188,93$ & & $305.003,68$ \\
Paraguaçu Pta & $68.379,00$ & $4.881,45$ & & $533.609,38$ \\
Jundiaí & $48.413,00$ & $12.550,00$ & & $625.459,84$ \\
Franca & $52.542,95$ & $6.234,91$ & & $493.670,46$ \\
Espírito Sto. & & $90.092,78$ & $16.179,04$ & & $619.475,03$ \\
Pinhal & & & & \\
Jacareí & & $44.951,00$ & $13.497,96$ & & $604.136,67$ \\
Taquarivaí & & $43.048,00$ & $10.890,50$ & & $433.802,89$ \\
Dracena & $34.197,00$ & $11.325,73$ & & $333.705,23$ \\
Itapetininga & $71.258,62$ & $25.881,46$ & & $480.014,44$ \\
São Simão & $35.299,00$ & $12.032,08$ & & $395.397,61$ \\
Rancharia & $32.282,00$ & $11.712,52$ & $6.236,75$ & $508.825,01$ \\
Cafelândia & $33.728,00$ & $15.942,73$ & & $357.725,33$ \\
Adamantina & $36.768,62$ & $5.848,45$ & & $483.296,33$ \\
Penápolis & $58.590,07$ & $19.146,67$ & $2.065,00$ & $544.359,05$ \\
Rio das Pedras & $32.948,00$ & $7.692,96$ & & $417.697,33$ \\
Cerqueira César & $30.154,00$ & $4.767,96$ & & $402.364,91$ \\
Jales & $94.228,61$ & $11.083,44$ & & $453.513,81$ \\
Monte Aprazivel & $44.267,00$ & $10.234,00$ & & $661.242,74$ \\
& & & &
\end{tabular}




\begin{tabular}{llllll}
\hline Município & $\begin{array}{l}\text { Outras } \\
\text { taxas } \\
\text { (R\$) }\end{array}$ & $\begin{array}{l}\text { Material de } \\
\text { consumo } \\
\text { (RS) }\end{array}$ & $\begin{array}{l}\text { Serviços de } \\
\text { terceiros (RS) }\end{array}$ & $\begin{array}{l}\text { Material } \\
\text { permanente } \\
\text { (RS) }\end{array}$ & $\begin{array}{l}\text { Total geral da } \\
\text { unidade (R\$) }\end{array}$ \\
\hline Miguelópolis & & $60.217,00$ & $9.921,85$ & $5.030,00$ & $363.243,11$ \\
Quatá & & $35.627,36$ & $7.373,51$ & & $517.645,60$ \\
Cândido Mota & & $69.108,00$ & $1.978,45$ & $2.138,00$ & $544.089,86$ \\
Sta. Rita Passa & & $40.994,00$ & $13.039,25$ & & $486.839,99$ \\
Quatro & & & & $498.011,00$ \\
Sta. Cruz do Rio & & $38.581,22$ & $7.872,00$ & & $492.058,05$ \\
Pardo & & & & $404.993,63$ \\
Itu & $29.577,00$ & $1.551,96$ & & $411.139,52$ \\
Mirassol & $38.622,00$ & $7.640,68$ & & $593.514,99$ \\
Iguape & $41.447,00$ & $9.198,50$ & & $515.280,02$ \\
Jaú & & $52.608,00$ & $16.518,00$ & & $268.399,26$ \\
Vera Cruz & $38.028,00$ & $6.537,00$ & & \\
Garça & 219,76 & $45.769,89$ & $13.132,45$ & & $443.681,67$ \\
\hline Presidente & & $23.964,00$ & $20.964,73$ & & $16.340 .752,70$ \\
\hline Venceslau & & & & & \\
São Manuel & & $49.673,00$ & $9.153,91$ & & \\
\hline Total & $5.687,20$ & $1.598 .308,28$ & $359.090,38$ & & \\
\hline
\end{tabular}

PROJOVEM - Custos para o CEETEPS - 1998

\begin{tabular}{llllll}
\hline Núcleo/ item & $\begin{array}{l}\text { Salários } \\
\text { monitores } \\
(\mathrm{R} \$)\end{array}$ & $\begin{array}{l}\text { Salários } \\
\text { cozinheiros } \\
(\mathrm{R} \$)\end{array}$ & $\begin{array}{l}\text { Quilometragem } \\
(\mathrm{R} \$)\end{array}$ & $\begin{array}{l}\text { Encontros } \\
(\mathrm{R} \$)\end{array}$ & $\begin{array}{l}\text { Total } \\
\text { anual/núcleo } \\
(\mathrm{R} \$)\end{array}$ \\
\hline Bananal* $^{*}$ & 24.480 & 7.140 & 2.100 & 1.993 & 35.713 \\
Maracai* $^{*}$ & 41.752 & 7.140 & 3.360 & 1.993 & 54.245 \\
Garça & 44.800 & 7.140 & 3.150 & 1.993 & 57.163 \\
Perúbe & 18.768 & 7.140 & 3.150 & 1.993 & 31.051 \\
Venceslau* & 55.080 & 7.140 & 4.200 & 1.993 & 68.413 \\
Promissão** & 57.936 & 7.140 & 4.410 & 1.993 & 71.479 \\
Rancharia & 43.260 & & 4.200 & 1.993 & 49.453 \\
Vera Cruz & 32.840 & 7.140 & 3.150 & 1.993 & 45.123 \\
Votuporanga & 29.040 & 7.140 & 2.100 & 1.993 & 40.273 \\
\hline Total & 348.036 & 57.120 & 29.820 & 17.937 & 452.913 \\
\hline
\end{tabular}

Fonte: CEETEPS.

${ }^{*}$ Núcleos que iniciaram as segundas turmas entre janeiro e fevereiro de 1999.

**Núcleo que inicou terceira turma em fevereiro de 1999. 


\section{Apêndice 2}

\section{Roteiro de entrevistas}

\section{Entrevista com os pais}

Núcleo:

Data:

1) Dados familiares (idade dos pais, número de filhos)

2) De quem é a propriedade da terra onde reside e trabalha sua família?

3) Qual a área total da propriedade?

4) Qual o período de tempo que o senhor vive ou trabalha no setor rural?

5) Possui empregados? Quantos?

6) Quais os principais produtos que sua família produz?

a) Destino da produção.

b) Quantidade comercializada.

7) Qual a receita bruta da sua família?

8) A sua família sobrevive só com o que produz na propriedade?

( Se não) O que mais fazem para sobreviver?

9) Qual a ocupação de sua esposa?

10) Que equipamentos o senhor utiliza para o trabalho na lavoura?

11) O senhor se considera um empresário rural?

12) O que o senhor entende por empresário rural? 
13) Seu filho estuda (além do PROJOVEM)?

(Se sim) A mão-de-obra de seu filho(a) faz falta para o trabalho na propriedade?

(Se não) Qual o motivo pelo qual ele(a) saiu da escola?

14) Quais os gastos mensais com o PROJOVEM?

Se o Sr. tivesse que pagar para alguém realizar o trabalho de seu filho na sua propriedade, quanto o Sr. pagaria?

15) Seu filho pensa em se mudar para a cidade?

16) Como está o interesse do seu filho(a) pelo trabalho na propriedade depois que ele entrou para o PROJOVEM?

17) O senhor pratica alguma coisa que seu filho tenha aprendido no PROJOVEM?

18) Você já conversou com o monitor de seu filho(a)?

19) Já foi ao núcleo onde seu filho(a) tem aula alguma vez?

20) O Sr. participa das reuniões da Associação de Pais?

21) O Sr. gostaria de morar na cidade?

22) O curso que seu filho está fazendo no PROJOVEM tem ajudado sua família?

Entrevista com os jovens

Núcleo:

Data:

Nome (opcional): 
Idade:

Sexo:

1) Você está na escola regular?

Se está, em que série está?

Se não, até que série você estudou?

Por que saiu?

2) Quantas horas você trabalha por dia?

3) O que você aprendeu na escola "normal" que ajuda você a realizar o seu trabalho?

4) Por que você resolveu entrar para o PROJOVEM?

5) Qual a diferença entre o PROJOVEM e as outras escolas?

6) Se tivesse oportunidade, você gostaria de cursar a escola agrícola?

7) Que técnicas e experiências você aprendeu no PROJOVEM?

8) Quais destes conhecimentos você (ou seu pai) põe em prática?

9) Quais as dificuldades que você encontra para colocar em prática os conhecimentos adquiridos no Núcleo, em sua propriedade ou comunidade?

10) Você sabe fazer um projeto?

11) Você sabe (ou está aprendendo) como calcular os custos e o retorno para saber o quanto vai ganhar ou perder em um investimento?

12) (Se sim) Você já utiliza este cálculo em sua propriedade?

13) Você vai ser um empresário rural? 
14) O que faz um empresário rural?

15) Qual o melhor jeito de ganhar dinheiro para quem tem uma pequena propriedade?

16) Que tipo de encontros você freqüenta dentro de sua comunidade?

17) Você já ouviu falar dos problemas sociais que existem no país em relação a preservação do meio ambiente, posse da terra, uso abusivo de agrotóxicos etc.. Porque você acha que esses problemas existem?

18) Você acha que uma Associação de Pequenos Produtores pode melhorar a renda da propriedade?

19) Você passa os conhecimentos que você aprende no PROJOVEM para sua família?

20) O seu relacionamento com sua família mudou depois que você entrou para o PROJOVEM?

21) O que você pretende fazer futuramente?

22) Com tudo que você aprendeu e está aprendendo, você acha que sua vida será melhor na cidade ou no campo?

23) O que melhorou em você ou em sua vida após ingressar no PROJOVEM?

\section{Entrevista com os monitores}

Núcleo:

Data:

1) Qual a sua formação?

2) Além de monitor do PROJOVEM quais outras atividades você exerce?

3) Você tem alguma experiência em empreendimentos rurais? De que tipo? 
4) Quanto do seu tempo mensal você dedica ao PROJOVEM?

5) Descreva detalhadamente alguma atividade realizada rotineiramente durante as sessões de núcleo?

Em quais destes processos você acredita estar sendo construtivista? Como?

6) Para o aprendizado dos jovens rurais carentes que freqüentam o PROJOVEM, o construtivismo é o melhor método? Porque?

7) Qual a sua função dentro do PROJOVEM?

8) Você acredita que a Associação Central é capaz de gerir o PROJOVEM?

9) Qual a importância dos cursos de capacitação na formação de monitores?

Porque?

Se importante, o que mais você considera importante na formação de monitores?

10) Você seria capaz de prosseguir o processo de aprendizagem dos jovens sem os cursos de capacitação? De que maneira?

11) Qual a maior preocupação dos monitores em relação ao PROJOVEM?

12) Você acredita que o PROJOVEM esteja formando jovens empresários rurais? Porque?

13) Quais são os benefícios (que você percebe no jovem) que o PROJOVEM trará para os jovens e suas famílias?

14) Existem conflitos no relacionamento entre monitores?

15) Você acredita que no PROJOVEM os jovens aprendem o bastante para tornar suas propriedades rentáveis para permitir um nível de vida razoável a suas famílias? Porque? 